Reporting Date: March 1974

Issued: May 1974

\title{
Environmental Surveillance At Los Alamos During 1973
}

\author{
Compiled by
}

Keith J. Schiager and Kenneth E. Apt

Contributors

Kenneth E. Apt

Sumner Barr

Raymond Garde

Thomas E. Hakonson

Stewart Ni. Lombard

Environmental Studies Group
John W. Nyhan

Richard J. Peters

William D. Purtymun

Keith J. Schiager 
Printed in the United States of America. Available from National Technical Information Service

U. S. Department of Commerce 5285 Port Royal Rosd Springtield, Virginia 22151

Price: Printed Copy S5.45; Microfiche \$1.45 


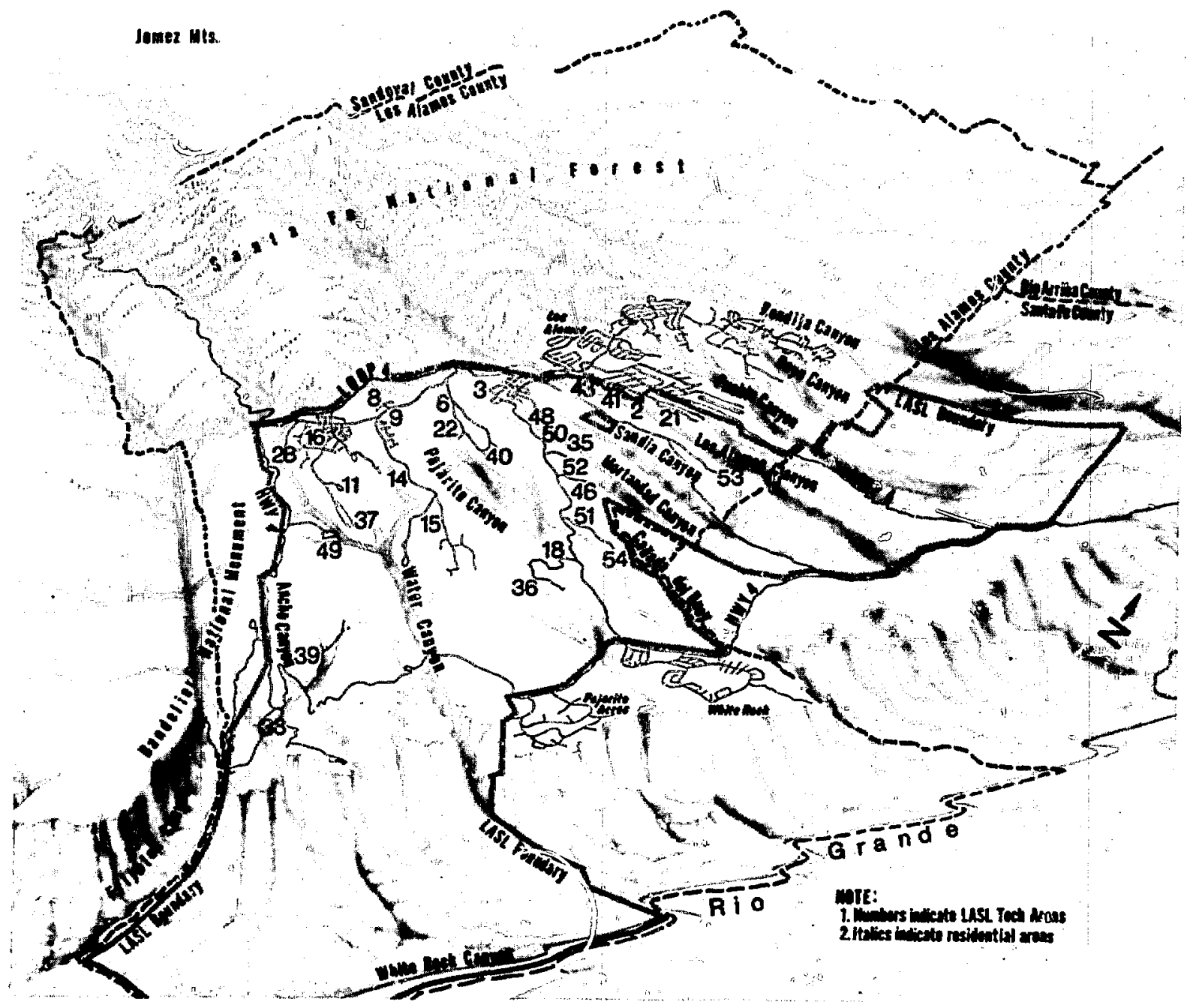

Topograpby of tbe Los Alamos, N. M., area. 


\section{CONTENTS}

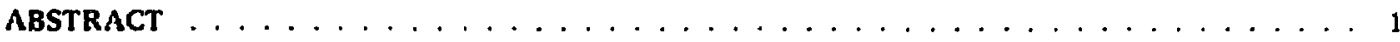

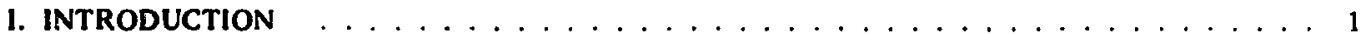

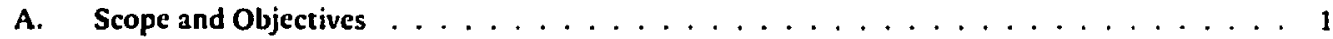

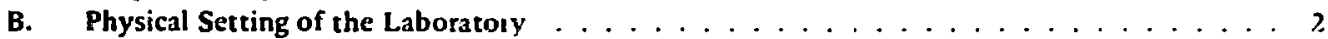

C. Population and Economy of the Area $\ldots \ldots \ldots \ldots \ldots \ldots \ldots$

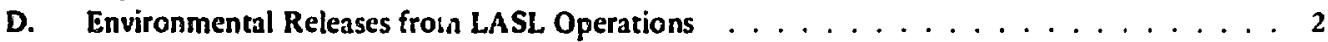

II. SUMMARY OF ENVIRONMENTAL MONITORING RESULTS $\ldots \ldots \ldots \ldots$

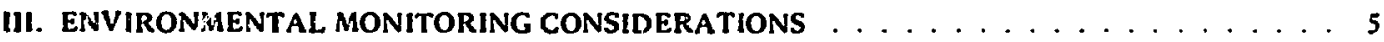

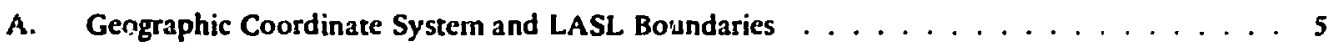

B. Units oi Measurement and Statistical Treatment of Data $\ldots \ldots \ldots \ldots$

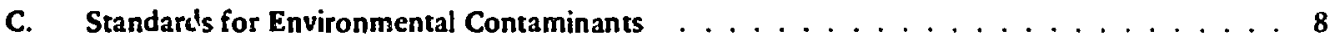

D. Quality Control Program ...................... 8

IV. EXTERNAL PENETRATING RADIATION EXPOSURE $\ldots \ldots \ldots \ldots \ldots \ldots$

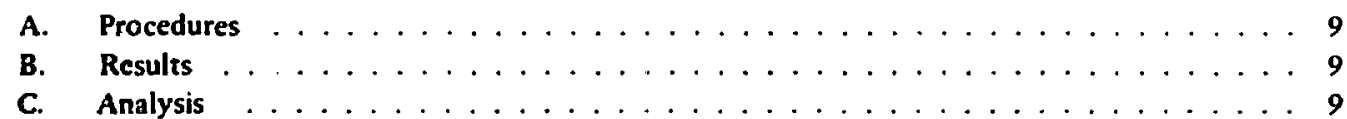

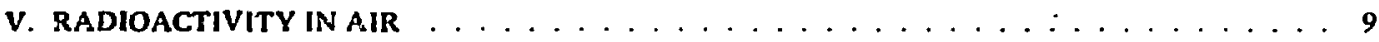

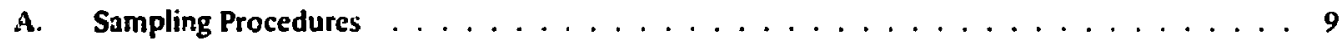

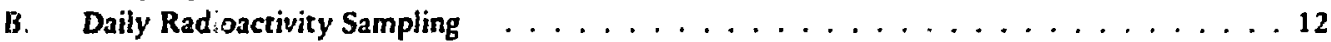

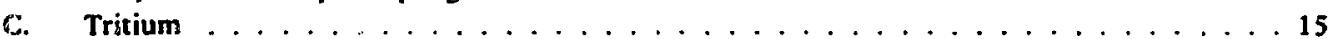

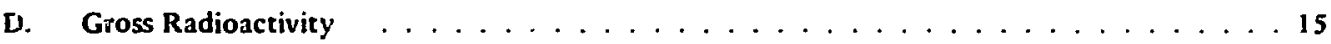

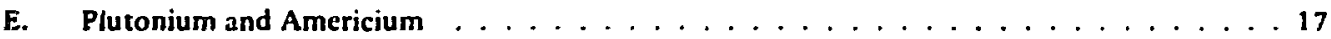

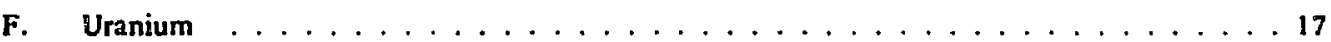

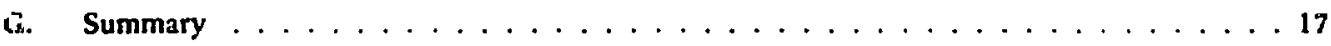

VI. RADIOACTIVITY IN SURFACE AND GROUND WATERS $\ldots \ldots \ldots \ldots \ldots \ldots$

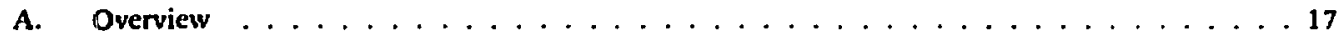

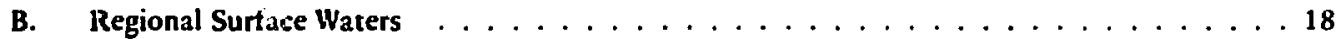

C. Ferimeter Surface and Ground Waters $\ldots \ldots \ldots \ldots \ldots$

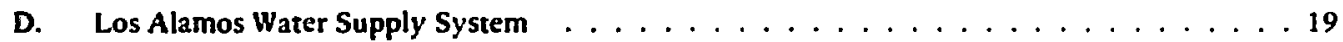

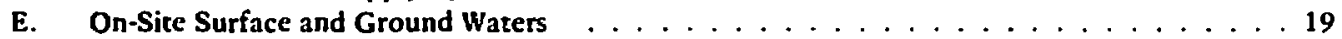

VII. RADIOACTIVITY IN LIQUID EFFLUENTS, SEDIMENTS, AND SOILS $\ldots \ldots \ldots$

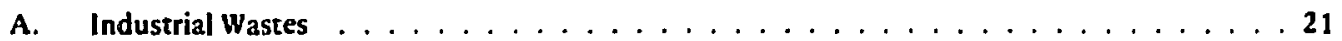

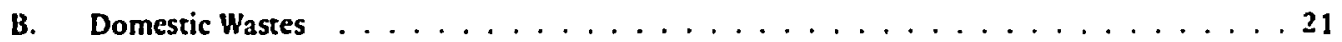

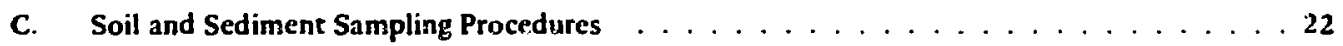

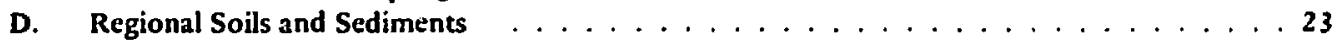

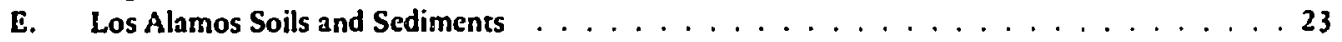

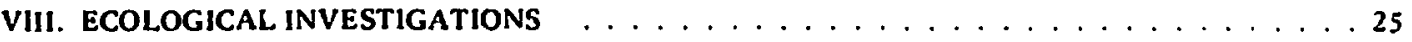

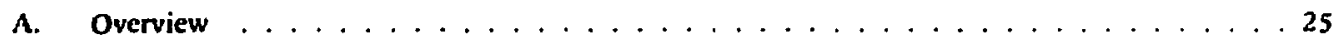

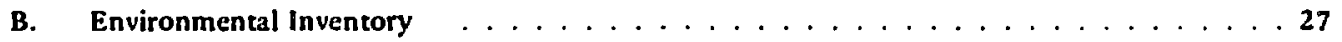

C. The Honeybee as a Potential Indicator Organism $\ldots \ldots \ldots \ldots$

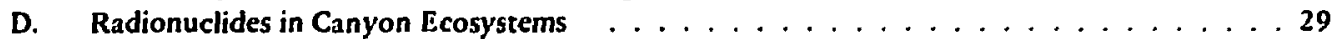

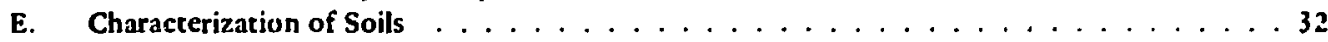




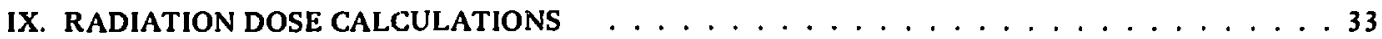

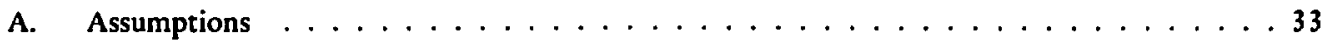

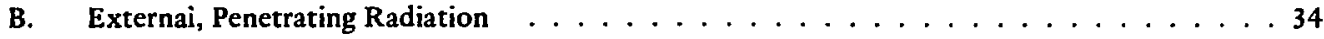

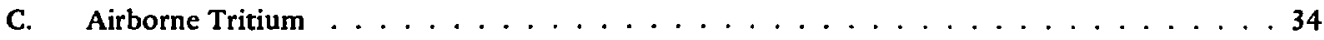

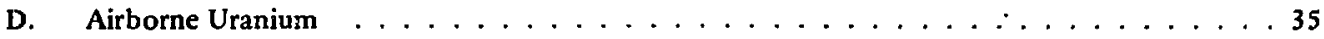

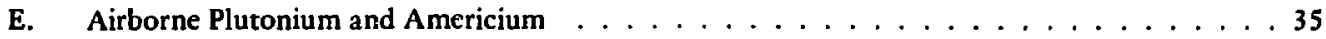

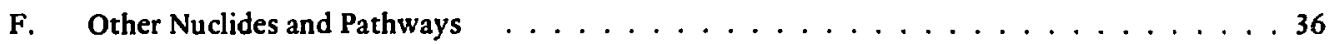

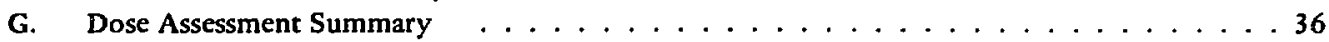

$\mathrm{X}$. CHEMICAL AND BIOLOGICAL QUALITY OF LIQUID EFFLUENTS . . . . . . . . . . 37

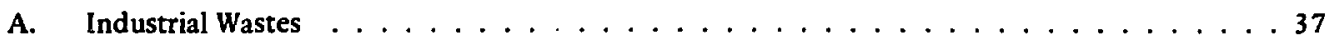

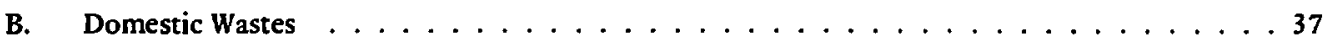

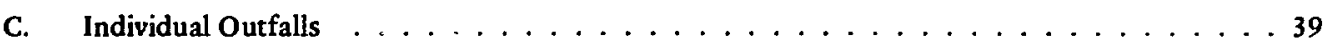

XI. CHEMICAL QUALITY OF SURFACE AND GROUND WATERS . . . . . . . . . . . 39

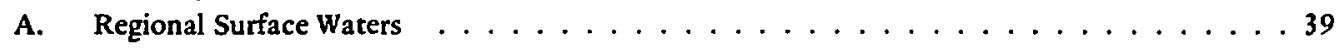

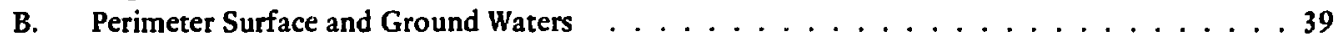

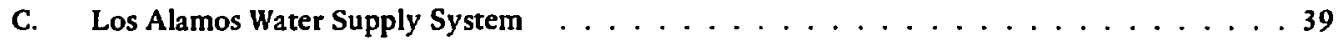

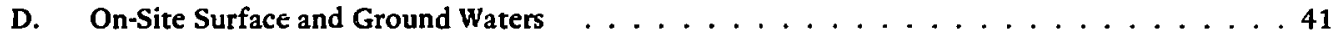

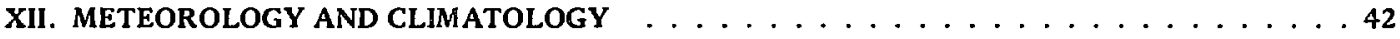

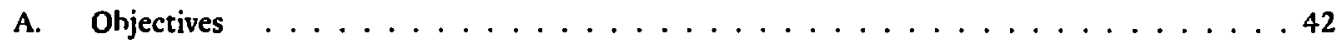

B. Climatological Records ....................... 44

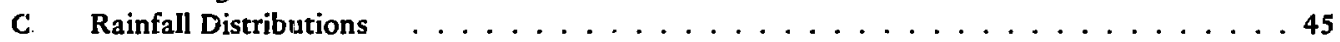

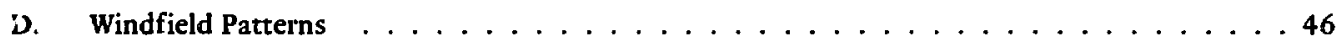

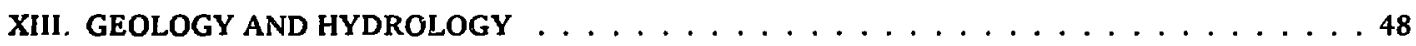

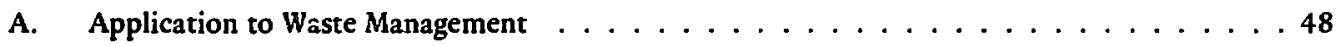

B. Flood Frequencies and Maximum Discharges $\ldots \ldots \ldots \ldots \ldots$

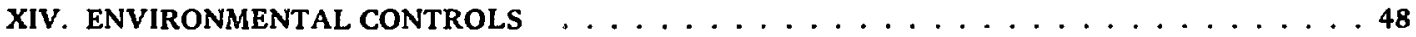

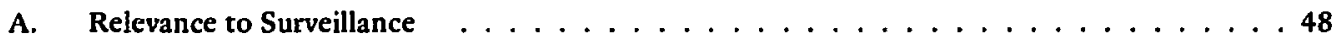

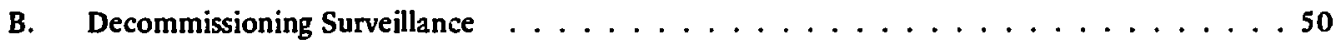

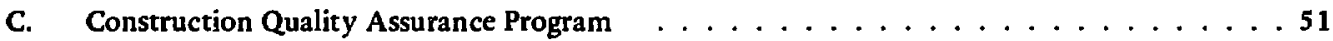

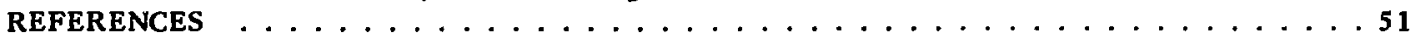

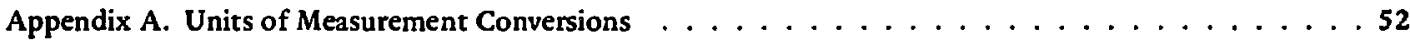

Appendix R. Standards Pertaining to Effluents and Environmental Monitoring . . . . . . . 53

Appendix C. Minimum Detection Limits (MDLs) for Routine Analyses of

Radioactivity in Typical Environmental Samples . . . . . . . . . . . . . . 54

Appendix D. Concentration Guides (CGs) for Uncontrolled Areas . . . . . . . . . . . . 55

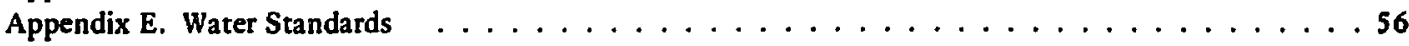

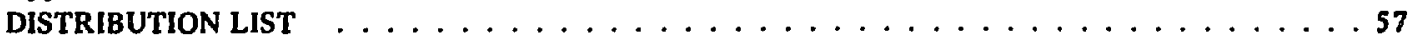




\section{TABLES}

I. Atmospheric radioactive effluent totals for $1973 \ldots \ldots \ldots \ldots \ldots$

II. Annual thermoluminescent dosimeter measurements $\ldots \ldots \ldots \ldots$

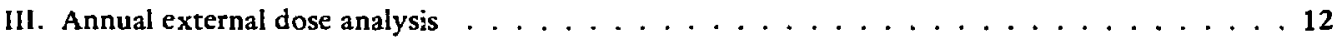

IV. Annual atmospheric tritiated water vapor and uranium concentrations $\ldots \ldots \ldots 13$

V. Annual atmospheric gross alpha and gross beta activity concentrations . . . . . . . . . 16

V1. Annual atmospheric ${ }^{238} \mathrm{Pu},{ }^{239} \mathrm{Pu}$, and ${ }^{241}$ Am concentrations $\ldots \ldots \ldots \ldots$

VII. Summary of annual atmospheric radioactivity monitoring $\ldots \ldots \ldots \ldots$

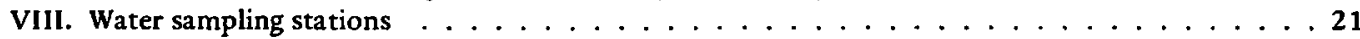

IX. Radioactivity in regional, perimeter, and Los Alamos water sources $\ldots \ldots \ldots 22$

$X$. Radioactivity in on-site surface and ground water sources $\ldots \ldots \ldots \ldots$

XI. Radioactivity in effluents from industrial waste teatment facilities $\ldots \ldots \ldots . \ldots 24$

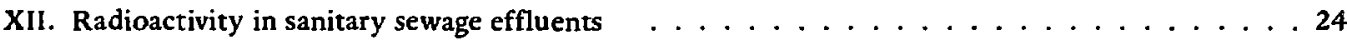

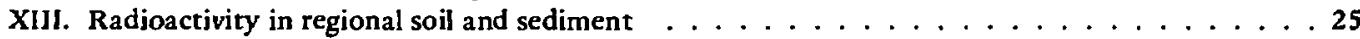

XIV. Radioactivity in soil and sediment in Los Alamos County . . . . . . . . . . . . 27

XV. External radiation exposure rates in liquid waste receiving canyons $\ldots \ldots \ldots$

XVJ. Plutonium in sediments in liquid waste receiving canyons $\ldots \ldots \ldots \ldots$

XVII. Plutonium in vegetation in liquid waste receiving canyons $\ldots \ldots \ldots \ldots \ldots$

XVIII. Plutonium in rodents in liquid waste receiving canyons $\ldots \ldots \ldots \ldots \ldots \ldots$

XIX. Chemical quality of major industrial liquid effluents $\ldots \ldots \ldots \ldots$

$\mathbf{X X}$. Biological quality of sewage effluents $\ldots \ldots \ldots \ldots \ldots \ldots$

XXI. Chemical quality of effluents from sewage treatment plants $\ldots \ldots \ldots \ldots$

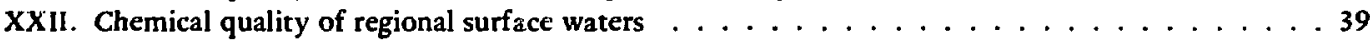

XXIII. Chemicals in perimeter surface and ground waters . . . . . . . . . . . 40

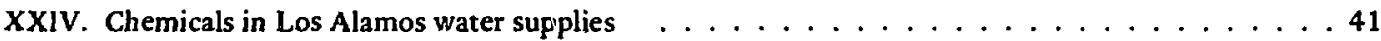

XXV. Arsenic and selenium in Los Alamos supply wells . . . . . . . . . . . . . 41

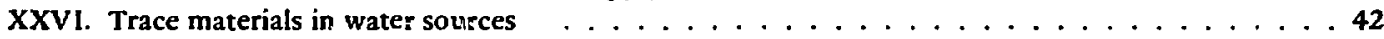

XXVII. Chemical quality of on-site surface and ground water sources $\ldots \ldots \ldots \ldots$

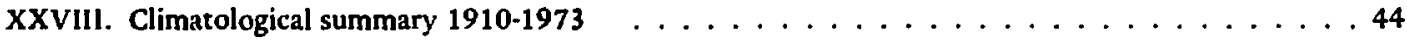

XXIX. Climatological summary for $1973 \ldots \ldots \ldots \ldots \ldots$

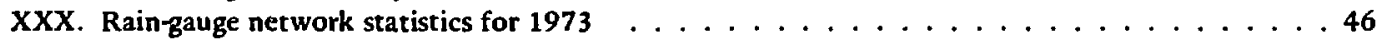

XXXI. Flood frequency and maximum discharge estimates $\ldots \ldots \ldots \ldots \ldots$ 


\section{FIGURES}

Topography of the Los Alamos, NM, area $\ldots \ldots \ldots \ldots \ldots \ldots$ iv

1. North-central New Mexico . . . . . . . . . . . . . . . . . . . . 3

2. Los Alamos County residential areas and LASL technical areas . . . . . . . . . . . 4

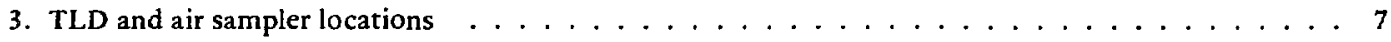

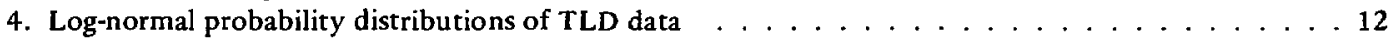

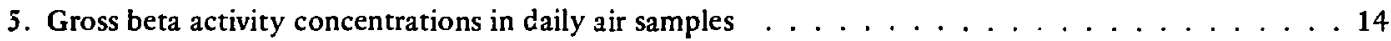

6. Log-normal probability distribution of atmospheric tritium concentrations . . . . . . . . 15

7. Log-normal probability distributions of airborne plutonium concentrations . . . . . . . . . . 19

8. Regional surface water, sediment, and soil sampling locations . . . . . . . . . . . . 19

9. Water sampling locations in White Rock Canyon of the Rio Grande . . . . . . . . . . 25

10. Water, sediment, and soil sampling locations on or near the LASL site . . . . . . . . . . . 26

11. Distribution of hourly and daily rainfall rates during $1973 \ldots \ldots \ldots \ldots$

12. Total precipitation isohyets for June through October $1573 \ldots \ldots \ldots \ldots$

13. Wind roses for Los Alamos, $1973 \ldots \ldots \ldots \ldots \ldots \ldots \ldots$

14. Surface water drainage areas . . . . . . . . . . . . . . . . . 49 


\title{
ENVIRONMENTAL SURVEILLANCE AT LOS ALAMOS DURING 1973
}

\author{
Compiled by
}

Keith J. Schiager and Kenneth E. Apt

\begin{abstract}
The CY 73 environmental monitoring program of the Los Alamos Scientific Laboratory (LASL) is described. Data are presented for coñecntracions of radioactivity measured in air, ground and surface waters, liquid effluents, sediments, and soils and are compared with those of AEC guides and/or data from other reporting periods. Leveis of external penetrating radiation measared in LASL environs are given. The average whole body radiation dose to residents of Los Alamos County resulting from LASL operations was calculated. Chemical and biological qualities of liquid effluents and surface and ground waters of LASL environs were determined, and are compared to applicable standards. Results of related environmental studies are presented. Ecological irivestigations include (a) an environmental inventory of LASL and environs, (b) the honeyhee as a potential tritium indicator organism, (c) radionuclides in Los Alamos area canyon ecosystems, and (d) physical and chemical characterization of Los Alamos area soils. Results are given of meteorological investigations of Los Alamos climatological rccords, rainfall distributions, and windfield patterns. There are also data pertaining to the geo-hydrological determination of flood frequencies and maximum discharges of Los Alamos area canyons. Environmental control activities are described which should be of benefit to LASL planning.
\end{abstract}

\section{INTRODUCTION}

\section{A. Scope and Objectives}

This report presents the results of the environmental monitoring programs conducted at the Los Alamos Scientific Laboratory (LASL) during the calendar year 1973. This facility is administered by the University of California for the U.S. Atomic Energy Commission (AEC) under Contract W-7405-ENG-36. The monitoring programs and evaluations of environmental quality were conducted mainly by the Environmental Studies Group (Group H-8) as portions of a continuing comprehensive environmental investigation.

Despite the use of highly efficient systems for treatment and purification of etítient streams, both gaseous and liquid, small quantitics of radionuclides routinely escape from the LASL site. Effluent monitoring is conducted continuously at all major release locations to document concentrations at points of release and total quantities released. Environmental monitoring is conducted throughout the area, both on the LASL site and in its environs, to evaluate the behavior of radioactive and nonradioactive contaminants in the biosphere.

Although the main objective of this report is to satisfy contractual requirements of the AEC as specified in AEC Manual Chapter 0513, the report also serves a broader function in providing public documentation of additional data on environmental quality in the vicinity of the Laboratory. Consequently, this report contains substantial amounts of material that go beyond the minimal requirements of the AEC. This additional information is provided in keeping with the philosophy of the AEC and the Laboratory to make available to the public information relating to environmental quality and controls. 


\section{B. Physical Setting of the Laboratory}

The Laboratory and the town of Los Alamos are locatcd in north-central Ncw Mexico (Fig. 1) on the Pajarito Plateau, situated west of the Rio Grande on the eastern slopes of the Jemez Mountains (p. iv). The Laboratory site covers about $110 \mathrm{~km}^{2}$ in and adjacent to Los Alamos County. The location was chosen for the atomic weapons laboratory during World War II because of its relative isolation; the area surrounding Los Alamos, including all of Los Alamos County and large portions of Sandoval, Rio Arriba, and Santa Fe Countics, remains largely undeveluped except for those areas occupied by the Laboratory facilitics and associated communities. Large tracts of land in the Jemez Mountains to the north, west, and south of the Laboratory site are held by the U.S. Forest Service and U.S. National Park Service. This land is largely covered by evergreen and aspen forests which stipport the usual variety of western mountain wildlife. A sacred portion of Indian land borders the Laboratory to the cast.

\section{Population and Economy of the Area}

The north-central portion of New Mexico contains approximately one-half million people. Nearly $70 \%$ of this population is concentrated in Albuquerque, slightly more than $100 \mathrm{~km}$ to the south. Another $10 \%$ is located in Santa $\mathrm{Fe}$, about $40 \mathrm{~km}$ to the southeast. Except for the population of Los Alamos, the remainder is distributed among small towns, ranging in sizc from a few hundred to a few thousand people, and Indian pueblos of a few hundred people. The nearest community is Española, about $20 \mathrm{~km}$ to the northeast, with a nopulation of about 2.000. Within Los Alamos County about $\$ 2000$ people live in the residential area of Los Alamos proper and the remaining 5000 reside in the White Rock area.

The cconomy of the Santa Fe-Los Alamos area is based largely on government operations, the large tourist trade, arts and crafts, agriculture, and some light and service industries, mostly associated with the tourist trade. LASL accounts for much of the fedcral employment, and the New Mexico state governmental offices, located in Santa Fe, provide many state jobs.

Agriculture is practiccd to a limited extent within $20-40 \mathrm{~km}$ of Los Alamos. In this area many people raise vegctables in home gardens, but very rarely depend on this activity for morc than half of their subsistence. Outside this area, much of the rural population practices agriculture, either for subsistence and income augmentation or on a strictly commercial basis. Limited truck farming has been made possible by irrigation in the river valleys. The principal crops of tree fruits, chili peppers, corn, and alfalfa are consumed primarily within the local area.

\section{Environmental Releases from LASL Operations}

The principal mission of the Laboratory is, as it has been since its inception in 1943, the design and development of nuclear weapons. This program is supported by extensive research programs in nuclear physics, hydrodynamics, conventional explosives, chemistry, metallurgy, radiochemistry, and biology. In addition to the weapons program, considerable effort is directed toward the peaceful uses of nuclear energy, including medium-energy physics (Clinton P. Anderson Los Alamos Meson Physics Facility), space nuclear propulsion, controlled thermonuclear fusion (Sherwood Program), laser and geothermal research, nuclear safeguards, biomedical research, and space physics. These activities are located in 29 active Technical Areas (TA) widely spread over the LASL site, as shown on p. iv and in Fig. 2.

Because the Laboratory is a large, diversified organization employing several thousand people engaged in fundamental and applied rescaich in the natural sciences, with emphasis on nuclear materials, the facilities include hundreds of potential sources of effluents and wastes. Processes with the potential for significant releases are confined to only a few locations and are rigorously controlled and monitored. However, there are many laboratory hoods, drains, and waste receptacles for which procedural controls are relied upon.

The radioactive materials released to the atmosphere from LASL operations are shown in Table I. Except for the entries in the last line of the table (for TA-15), the data were obtained by stack effluent monitoring.

The major emphases of the environmental monitoring program are dictated by the types and quantities of potentially hazardous materials used in LASL programs and by the unique ecology and geology of this location. Substantial emphasis is placed on the analysis for tritium, uranium, and plutonium in samples of environmental media. Fission product radionuclides are of lesser concern, although specific analyses are made for radioactive species of cesium and iodine in selected samples. Because of the minimal agricultural activities in the immediate vicinity of the LASL site, monitoring of radionuclides in human food chains is not emphasized in this program as it is in most other comparable environmental monitoring programs. 


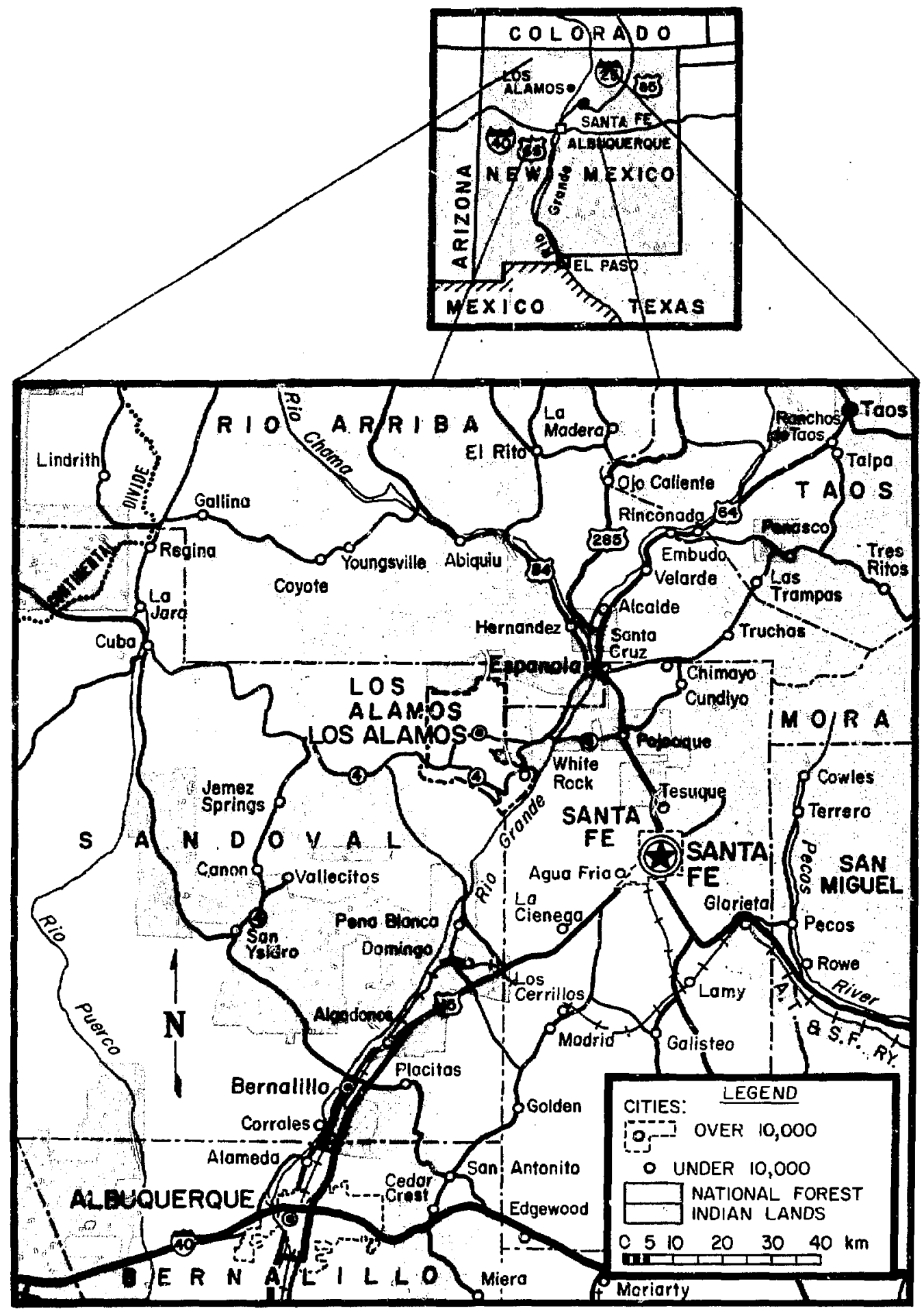

Fig. 1 .

Nortb-central New Mexico. 


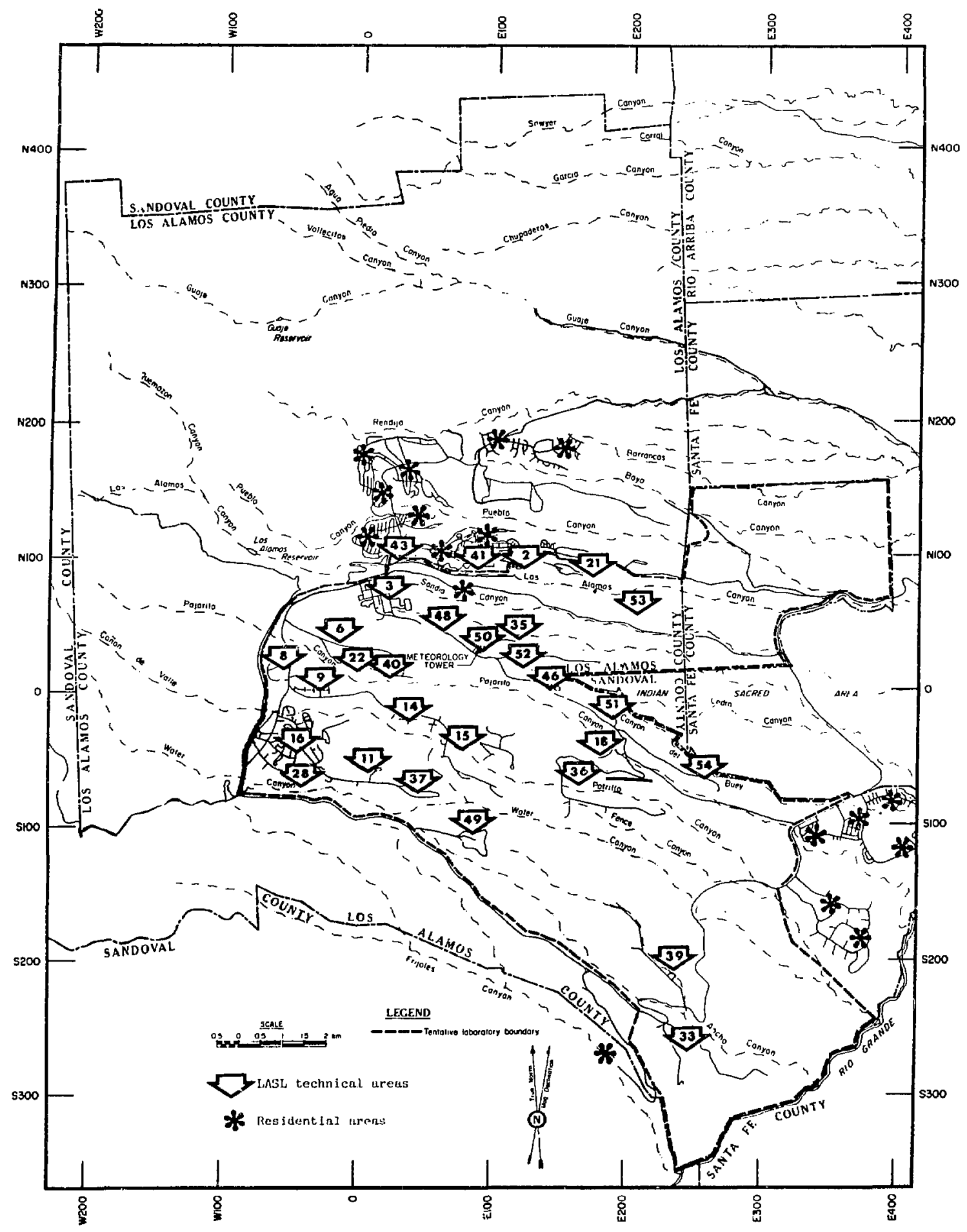

Fig. 2.

Los Alamos County residential areas and LASL technical areas (numbered). 
TABLE I

ATMOSPHERIC RADIOACTIVE EFFLUENT TOTALS FOR 1973

\begin{tabular}{|c|c|c|c|c|c|c|c|c|c|c|}
\hline Location & $\begin{array}{l}241^{4} \mathrm{Am} \\
238^{2} \mathrm{Pu} \\
29^{9} \mathrm{Pu} \\
(\mu \mathrm{Ci})\end{array}$ & $\begin{array}{l}2{ }^{39} \mathrm{U} \\
2{ }^{4} \mathrm{U} \\
23{ }^{3} \mathrm{U} \\
(\mu \mathrm{Ci})\end{array}$ & $\begin{array}{l}{ }^{238} \mathrm{U}^{\mathrm{B}} \\
(\mathrm{kg}) \\
\end{array}$ & $\begin{array}{l}{ }^{232} \mathrm{Th} \\
(\mathrm{kg}) \\
\end{array}$ & $\begin{array}{l}\mathrm{MFP}^{\mathrm{b}} \\
(\mathrm{mC} C i) \\
\end{array}$ & $\begin{array}{l}{ }^{131} \mathrm{I} \\
|\mathrm{mCi}|\end{array}$ & $\begin{array}{l}{ }^{80} \mathrm{Rb} \\
(\mathrm{mCl})\end{array}$ & $\begin{array}{l}{ }^{233} \mathrm{Xe} \\
135 \mathrm{Xe} \\
(\mathrm{Ci}) \\
\end{array}$ & $\begin{array}{l}4 A r \\
\text { (Ci) } \\
\end{array}$ & $\begin{array}{l}{ }^{3} \mathbf{H} \\
\text { ICil }\end{array}$ \\
\hline TA-2 & - & - & - & - & - & - & 1.3 & 210 & 270 & - \\
\hline$T A-3$ & 7300 & 310 & 640 & 0.14 & 13 & 4.2 & - & - & - & - \\
\hline TA-9 & - & - & - & - & - & - & - & - & - & 36 \\
\hline$T A-2 I$ & 1400 & 910 & - & - & 0.001 & - & - & - & - & 4 \\
\hline$T A-33$ & - & - & - & - & - & - & - & - & - & 3900 \\
\hline TA-35 & 2.4 & - & - & - & - & - & - & - & - & 1200 \\
\hline$T A-41$ & 1.5 & - & - & - & - & - & - & - & - & 59 \\
\hline$T A-43$ & 0.5 & - & - & - & - & - & - & - & - & - \\
\hline$T A-46$ & - & 2.2 & - & - & - & - & - & - & - & - \\
\hline$T A-48$ & 20 & 2.0 & - & - & 1.0 & - & - & - & - & - \\
\hline TA-50 & 2.5 & - & - & - & 0.017 & - & - & - & - & - \\
\hline$T A-35$ & - & - & - & - & - & - & - & - & - & 930 \\
\hline
\end{tabular}

\section{SUMMARY OF ENVIRONMENTAL MONITORING RESULTS}

The results of the monitoring program for this reporting period confirm the generally low radiation levels previously noted ' in the Los Alamos environs. Measurements of gross radioactivity in air and precipitation revealed concentrations sinilar to those measured at other locations in the northern hemisphere where activity is entirely attributable to the presence of worldwide fallout. Airborne plutonium and tritium measurements revealed that Laboratory activities have slightly elevated the levels of both materials above the concentrations expected from global fallout.

Radiation dose calculations were made for individuals susceptible to the maximum off-site contributions by the Laboratory, and for the general public in the vicinity of the Laboratory. The only contribution to whole body dose that could be attributed to the Laboratory was from airborne tritium (oxide). The maximum potential dose from tritium to an off-site person was $0.12 \mathrm{mrem} / \mathrm{year}$; to the residents of Los Alamos County, the estimated annual dose was $0.007 \mathrm{mrem}$. These values represenc $0.02 \%$ and $0.004 \%$ of the individual and population dose limits, respectively. A total population dose of 0.14 man-rem was calculated as the Laboratory's tritium contribution to total dose.

Maximum lung doses to off-site individuals, and average lung doses to Los Alamos residents, resuiting from airborne actinides, were calculated to be $0.007 \%$ and $0.01 \%$ of the appropriate dose limits.

\section{ENVIRONMENTAL MONITORING CONSIDERA- TIONS}

\section{A. Geographic Coordinate System and LASL Boundaries}

All Los Alamos County (and vicinity) locations referenced in this report are identified by the L.4SL Cartesian coordinate system first shown in Fig. 2. Most internal LASL documentation, including maps and survey markers, is referenced to this coordinate system. Hence, we employ this system here because of its acceptance and convenience. The LASL coordinate system was established somewhat arbitrarily during the early years of the Laboratory and is completely independent of the U.S. Geological Survey and the New Mexico State Survey 
coordinate systcms. The majoz courdinate markers shown on the maps are at $10000-\mathrm{ft}(3.048 \cdot \mathrm{km})$ intervals, but for the purposes of this report, locitions are iucntificd to the nearcst $1000 \mathrm{ft}(0.30 \mathrm{~km})$. For example, the air sampling station at TA-3 3 (sec lighs. 2 and 3 ) has coordinates $\$ 250$ E230 and is in the soutbeast quadrane approsimately $25000 \mathrm{ft}(7.6 \mathrm{~km})$ south and $23000 \mathrm{fr}(7.0 \mathrm{~km})$ cast of the coordinate eenesr.

The LASL botandaries are shown on p. iv and on stubequent Los Nlamos area maps in this teport. Not all of this arta is routincly controlled by LASL. because some of the more remote and litele used regions are atecessible to the public. Howeter, all area within the 1.ASt perim. cter, including public roads. is considered a controlled arca. The Laboratony has the capability of strict control over these areas should the need arise. Much of the Luboratony area is, of coursc, restricted for rtasons of security and/or safery.

\section{B. Units of Measurement and Statistical Treatment of Data}

As of 1974, all LASl, scicintific and tcehnical documentation uses metric units, and conversion to the international System of Units (SI) is advised wherever practica. ble. We have atempted to comply with Si notation here. with certain exceptions. First, the non-Si units curic (Ci). liter (l). gram (g), and roentgen equivalent man (rem) are used. Second, in accordance with AEC Manual Chapter 0513 , values of radioactivity in air and water are reported in units of $\mu \mathrm{Ci} / \mathrm{m} \ell$. For the benefit of readers who may not be familiar with SI. Appendix A gives conversion factors for units used in this report.

Most of the data in this report are annual averages of individual measurements of environmental conditions or concentrations. For many ervironmental measurements, particularly those from which a chemical or instrumental background must be subtracted, ic is possible to obtain net values that are lower than the minimum detection limit (MDL) of the system; it is not uncommon for individual measurements to result in values of zero or negative numbers. In spite of the fact that a negative valuc for an environmental measurement does not represent a physical reality, a valid long-term average of many measurements can be obtained only if the very small or negative values are included with the larger, positive values. For this reason, the primary valuc shown in each of the numerical tabulations in this report is the actual valuc obtained from an individual measurement or group of measurements. The primary values thus listed are those used in making subsequent statistical analyses and in evaluating the real cnvironmenral impact of Laboratory operations. Ifowever, to provide as indication of the validity of each numerical valuc in the tables, an additional value is included in parentheses immediatcly following each primary numerical valuc. The interpretation of the value in parentheses is designated by the sign preceding that value:

I. $( \pm X)$ indicates that the primary valuc preceding the parentheses is greater than the MDL, and the parenthetical value indicates the range of the $95 \%$ confidenec interval for the primary value.

2. $(\langle Y)$ indicates that the primary value preceding the patentheses is lower than the MDL, and the parenthetical value represtents the MDL for that particular measurtmene.

The statistical distribution of annual averages of environmental conditions or concentrations deserves attention. Most annual-awcrage data are analyzed with respect to a Gaussizn or normal distribution. This well known law describes the frequency distribution of many physical measurements. For examplc, the distribution of annualaverage gross alpha radioactivity concentrations measured at our air sumpling stations obsys such a probability law. The frequency $P(c)$ of a concentration $c$ is stated as:

$$
P(c)=\left(1 / \sigma_{c} \sqrt{2 \pi}\right)\left(x p\left[-(c-\bar{c})^{2} / 2 \sigma_{c}{ }^{2}\right] .\right.
$$

where $\vec{c}$ is the arithmetic mean of the distribution, and $\sigma_{c}$ is the standard deviation (std dev). This distribution has the symmetrical "bell" shape around the central value $\vec{c}$. and $\sigma_{c}$ is the difference between the 84.13 percentile concentration and the $\$ 0$ percentile concentration $\bar{c}$ (and. identically, the difference between $\bar{c}$ and the $15.87 \mathrm{per}$ centilc conecentration).

Many environmental data, however, do not fit the normal distribution law; instcad, the distributions aze of ten asymmetrical or skewed toward the higher values. It has been observed that even though the data are not normally distributed, the logarithms of the data quite often obcy the normal law. As an example, data for external penetration radiation dose $x$ (determined from our passive-dosimeter array) can be described lognormally. The frequency distribution $P(\ln x)$ of the natural logarithms of dose $\ln x$ is described by

$$
\left.P(\ln x)=(1 / m \sqrt{2 \pi}) \exp \mid-(1 n x-m)^{2} / 2 n^{2}\right] \text {. }
$$

where $m$ is the arithmetic mean of the values of $\ln x$ and is equal to the logarithm of the geometric mean, and $n$ is the associated std dev of the arithmetic mean. The geometric mean $\bar{x}_{g}$ of the values of $x$ is then given by $\bar{x}_{g}=\exp [m]$ and the geometric std dev $\left.\sigma_{g}=\exp \mid n\right]$. The geometric mean of a log-normal distribution is closer to the median value than is the arithmetic mean. The multiplicative parameter $\sigma_{\mathrm{g}}$ is simply the ratio of the $\mathbf{8 4 . 1 3}$ 


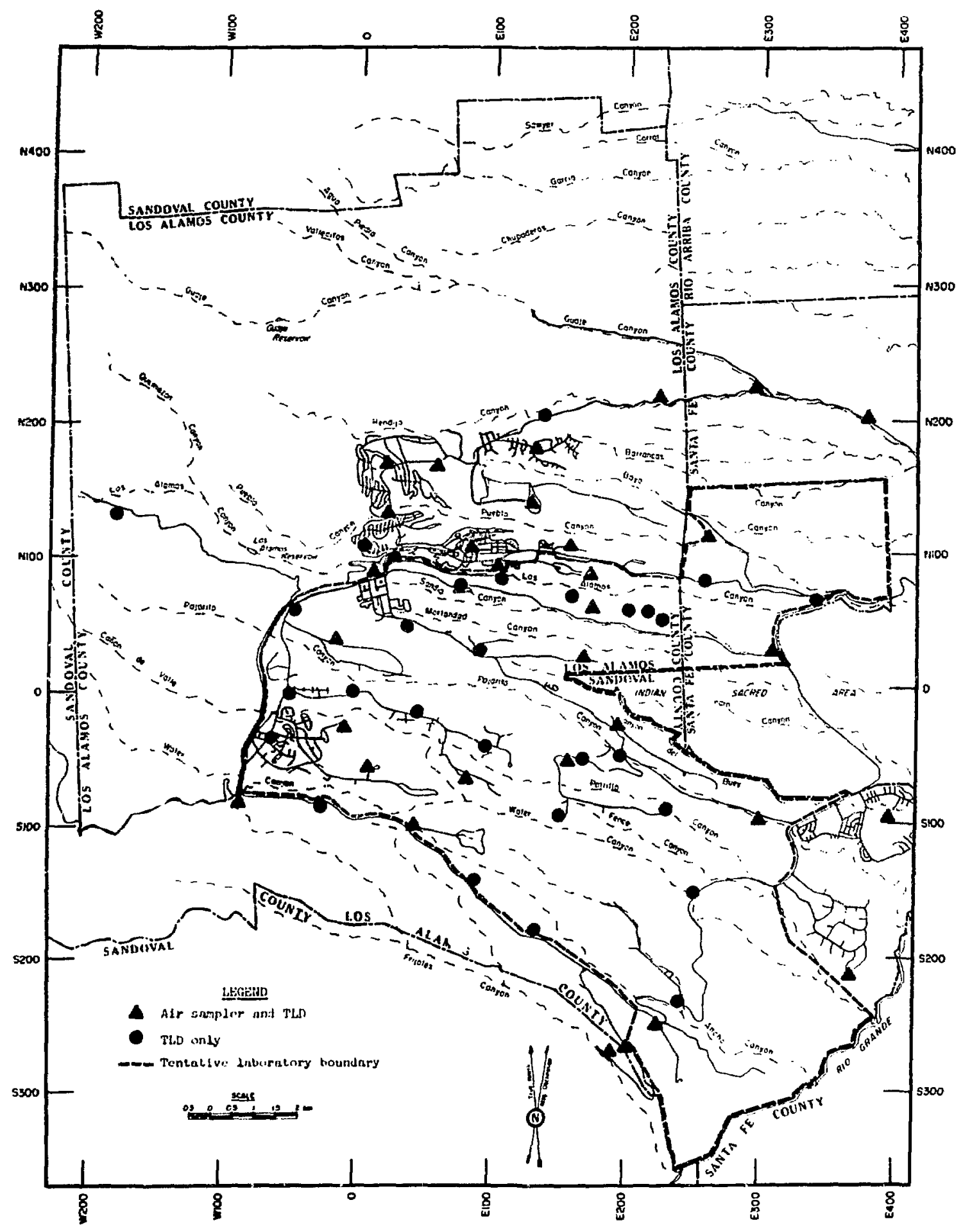

Fig. 3.

TLD and air sampler locations. 
percentile value of $x$ to the 50 percentile value $\bar{x}_{g}$ (and, identically, the ratio of $\bar{x}_{g}$ to the 15.87 percentile valuc). Hence, $\bar{x}_{g}$ and $\sigma_{g}$ describe the log-normal distribution completely. The geometric values $\bar{x}_{g}$ and $o_{g}$ are related to the arithmetic mean and std dev $\bar{x}$ and $\sigma_{s}$ by the following relationships:

$$
\begin{aligned}
& \bar{x}=\exp \left[m+n^{2} / 2\right] \\
& \sigma_{x}=\bar{x}_{\left.\left(\exp \mid n^{2}\right]-1\right)^{1 / 2}}
\end{aligned}
$$

Inspection of a frequency histogram of the data gives an indication of the distribution characteristics. Probability graph paper is also useful in evaluating the statistical distribution both for Gaussian and log-normal data sets. We have used the log-normal probability distribution in describing some of the environmental data reported herein. It is intended that the use of the geometric parameters $\bar{x}_{\mathrm{g}}$ and $\sigma_{\mathrm{g}}$ will tell more abour the dara set than would the conventional arithmetic mean and std dev.

\section{Standards for Environmental Contaminants}

The concentrations of radioactive and chemical contaminants in air, water, sediment, soil, plant, and animal samples collected throughout the environment are compared with the standards contained in regulations of scveral federal and state agencies to verify the compliance of the Laboratery with all pertinent standards. LASL operations, including environmental quality control, are conducted in accordance with the directives and procedures contained in the AEC Manual, particularly Part 0500: Health and Safety. The chapters most relevant to environmental control and monitoring are:

Chapter 0510, Prevention, Control and Abatement of Air and Water Poilution.

Chapter 0511, Radioactive Waste Management.

Chapter 0513, Effluent and Environmental Monitoring and Reporting.

Chapter 0524, Standards for Radiation Protection.

Chapter 0550, Operational Safety Standards. (Excerprs from this chapter, listing prescribed and recommended stasidards, can be found in Appendix B.)

In the case of radioactive materials in the environment, the standards contained in AECM 0514 (see Appendix D) take precedence over all other federal or state regulations. For other kinds of pollutants, e.g. biological or chemical, the controlling standards are those promulgated by either the Environmental Protection Agency or the appropriatc state agencies. liederal air pollution standards are contsined in "T:PA Regulations on $\Lambda$ ir Pollution from liederal Government Activities," 40 CFR76 (36 fR 22417, Nov. 25, 1971). The "New Mexico linvironmental Injrovement Board Ambient Air Zualiry Standards and Air Quality Control Regulations" (adopted Jan. 23, 1970; scven revisions through July 29, 1972) also definc ambient air quality standards, but standards for emission controls are limited to combustion processes and special industrics.

The bisic standards for drinking water are contained in "PHS Regulations on Drinking Water Standards," 42 CFR 72. 201-207* (27 JK 2152, Mar. 6, 1962), which specifies bacteriological, physical, and clicmical characteristics. Equivalent standards are contained in "New Mexico Water Quality Control Commission Regulations," Reg. 4, "Efflucent Quality" (adopted March 4, 1968), and Reg. 6. "Discharge of llazardous Substances" ?adopted Aug. 27. 1971). Additional surface stream standards, primarily for protection of recreational resources, are contained in "Water Quality Siandards for Intrastate Waters and Tributaries to Interstate Streams," New Mexico Water Quality Control Commission (adopted June 30, 1970).

\section{Qualizy Control Program}

The quality control program for 1973 dealt primarily with analytical chemistry procedures for plutonium in environmental samples. The retention of plutoniun tracer added to air filters was investigated in conjunction with the atmospheric radioactivity monitoring program. Systematic procedural losses of plutonium from air filcer samples during ashing and processing werc quantificd. Plutonium determinations of water samples were studied by conducting analyses of "spiked" samples, analyses of blank samples, and analyses of replicate samples. In general, the procedures for plutonium determination in water samples were found to be satisfactory. The quality control program for routine sijil sample analyses consisted of plutonium analyses of spiked samples, blank samples, and replicate samples. The results of the blank and spiked sample analyses gave no indication of anslytical inadequaeies. The replicate determinations, however, had an incongruity of results, probably caused by sampling procedures and inhomogeneity of soil samples.

A general problem identified in the quality control program was that of laboratory plutonium contamination of environmental samples. The plutonium analytical laboratory is located in the basement of a plutonium liquid waste treatment facility, which is clearly an undesirable location for low-level radioactivity determinations. Many erratic and unrealistic plutonium results can probably be 
explained by contamination of enviroumental samples in the analysis laboratory. As space becomes available, the environmental plutonium analysis laboratory is being relocated to an uncontaminated ares.

\section{EXTERNAL PENETIRATING hadiation EXPOSURE}

\section{A. Procedures}

Radiation exposure from external penetrating radia. tion (gamma and $x$ rays) is monitored by 65 thermoluminescent dosimeters (TL.Ds), of which 20 aac located beyond the Laboratory boundaries and 17 are located along the perimeter of the Laboratory site (within $\approx 1 / 2$ $\mathrm{km}$ of the bouncisy). The remaining 28 are locatcd on Luboratory property (Fig. 3). liach of the TLD monitors is composed of three Harsilaw TDS-100 chips, $3.2 \mathrm{~mm}$ square by $0.9 \mathrm{~mm}$ thick, which are cut from single crystals of $\mathrm{LiF}$ containing the natural isotopic abundance of ${ }^{6} \mathrm{Li}$ and ${ }^{7} \mathrm{Li}$. The chips are wrapped in alumisum foil and placed in an opaque 7-ral polycthylene vial for placement in the field. Most TLDs are exchanged quarterly, although a few are exchanged monthly to permit more detailed analysis of temporal variations at sclected locations.

\section{B. Results}

The annual average dose rates determined from the TLD monitoring program are summarized in Table II according to off-site, perimeter, and on-site locations. The observed temporal variations from all stations are consistent and are of the same order of magnitude as the spatial variations of annual average dose rates. The numbers given parenthetically with the at'crage dose rates are the 95\% confidence level errors associated with the data. It should be noted that the average elevation of the 20 off-site stations is $2.06 \mathrm{~km}$, compared with an average elevation of $2.15 \mathrm{~km}$ for the perimeter and on-site stations. Variations in cosmic radiation duc to differences in elevation, combined with variations due to geological setting for the various monitoring stations, complicate the analysis of external exposure contributions from Laboratory operations. No attempt was made to normalize the data to correspond to a constant elevation, but efforts are being made to eliminate the anomalous effects caused by monitoring station cnvirons.

\section{Analysis}

In iletermining the mean of station annual dosts, the distribution of the annual dosus must be considered. By determining the commonly used arithmetic mean and std dev, one presumes a normal, i.e., Gaussian, distribution. For the TLD annual dose dara, the presumption of normal statistics is inapproprinte. The data are not distributed in a characteristic "bcll" shape, but are distributed asymmetrically coward the higher values. The physical reasons for this skewing include increased dose from geological setting and, in some cases, Laboratory operations. Data of this kind more closely restmble a log. normal distributien, where the distribution of the logarithms of the data is characteristically bell shaped. The geometric mean of such a distribution is closer to the median valuc than is the arithmetic mean. The geometric std dev $\sigma_{g}$ is a unitless, multiplicative number that represents the ratio of the 84.13 perecentile value to the 50 percentile value and, identically, the 50 percentile value so the 15.87 percentile valut.

Table III shows a comparison of arithmeric and geometric statistical treatments for annual data from TLDs. Even after excluding the three stations exposed to known radiation from $T A-18$, the distributions for the three location groups are amenable to log-normal treatment. (Nuclear physics experiments at TA-18 use nuclear fission sritical assemblies. These opcrations give bursts of gamma rays and neutrons which are obscrvable in the immediate environs.) Figure 4 shows the log-normal analysis for each location group. Also shown in Fig. 4 is a cypical 95\% confidence level error associated with the mean annual dose for an on-site station. This error bar gives an indication of the inherent uncertainty in the annual dose data for the various stations. It is evident that the doses received at on-site locations are statistically indistinguishable from those for off-sitc and perimeter locations.

\section{RADIOACTIVITY IN AIR}

\section{A. Sampling Procedures}

Concentrations of atmospheric radioactivity were measured at 36 continuously operating air sampling stations in Los Alamos County and vicinity. Station locations are shown in Fig. 3, and map coordinates identify the locations in the data tabulations. Samples were 
TABLE II

ANNUAL THERMOLUMINRSCENT DOSIMETER MEASUREMENTS

\author{
Station \\ Location \\ Orf-site stetions: \\ 1 Guaje Booster 2 \\ 2 Guaje Bosster 1 \\ 3 Sportsanns' Club \\ 4 Well G-1 \\ 5 Barranca School \\ 6 Arkansas Avenue \\ $T$ Golf Course \\ 8 well LA-3 \\ 9 Curbres School \\ 10 Pajarito Ski Area \\ 11 Diamond Drive \\ 12 i 7 th Street \\ 13 suller Lodge \\ 14 Totavi \\ 15 infite Rock STP \\ 16 Pajarito Acres \\ 17 Sandelier IHQ \\ 18 Española \\ 19 Pojogque \\ 20 Sante Fe
}

Pertmeter Stetions:

21 I. A. Airport

22 בayo STP

23 TA-43

24 Acorn Street

25 TA-3

26 Los Alamos Highwey

27 Highway 4

28 w. Jemez Roed

29 Well PM-1

30 TA-16

31 พ. Jemez Roed

32 Highway 4

33 TA-49

34. Pajarito Booster 1

35 aighway 4

36 Highwey 4

37 Bandelier Lookout

\begin{tabular}{|c|c|}
\hline Coordinates & $\begin{array}{l}\text { Elevetion } \\
\text { (kD) }\end{array}$ \\
\hline "1220 Е220 & 2.03 \\
\hline n270 E300 & 1.92 \\
\hline H200 E140 & 2.10 \\
\hline 120023390 & 1.85 \\
\hline $1180 \equiv 130$ & 2.22 \\
\hline$m 170 \approx 20$ & 2.26 \\
\hline $11605: 0$ & 2.22 \\
\hline hISO E490 & 1.75 \\
\hline $11140 \mathrm{E} 130$ & 2.25 \\
\hline$m 130$ พ180 & 2.80 \\
\hline$w 130 \mathrm{E} 20$ & 2.21 \\
\hline H110 E 0 & 2.24 \\
\hline JIL E 90 & 2.22 \\
\hline N100 E440 & 1.77 \\
\hline S 90 E390 & 1.92 \\
\hline s210 E370 & 1.93 \\
\hline \multirow[t]{4}{*}{ S270 E190 } & 1.85 \\
\hline & 1.70 \\
\hline & 1.78 \\
\hline & 2.13 \\
\hline Arith Mean: & : 2.06 \\
\hline
\end{tabular}

$\begin{array}{llr}\text { N110 E160 } & 2.15 & 4 \\ \text { N110 E260 } & 1.99 & 13 \\ \text { N100 E } 20 & 2.22 & 13 \\ \text { N100 E110 } & 2.21 & 13 \\ \text { N } 80 \text { E } 10 & 2.25 & 13 \\ \text { N } 80 \text { E260 } & 2.07 & 13 \\ \text { N } 70 \text { E350 } & 1.92 & 13 \\ \text { N } 60 \text { W } 50 & 2.35 & 13 \\ \text { N } 30 \text { E310 } & 1.98 & 13 \\ \text { S 40 W } 60 & 2.33 & 13 \\ \text { S } 80 \text { W } 90 & 2.32 & 4 \\ \text { S 80 W 30 } & 2.26 & 13 \\ \text { S100 E 40 } & 2.21 & 13 \\ \text { S100 E300 } & 2.00 & 13 \\ \text { S140 E 90 } & 2.15 & 13 \\ \text { S180 E130 } & 2.10 & 13 \\ \text { S270 E200 } & 1.98 & 13 \\ \text { Arith Mean: } & 2.1 .5 & \end{array}$

Averafe Dose Hate (mrad/day)

$0.45(=0.30)$

$0.41(=0.08)$

$0.49(* 0.10)$

$0.40( \pm 0.08)$

$0.36( \pm 0.07)$

$0.32( \pm 0.06)$

$0.42( \pm 0.08)$

$0.33( \pm 0.07)$

$0.62( \pm 0.13)$

$0.40( \pm 0.08)$

$0.39( \pm 0.08)$

$0.37( \pm 0.07)$

$0.43( \pm 0.09)$

$0.39( \pm 0.08)$

$0.33( \pm 0.06)$

$0.33( \pm 0.07)$

$0.53( \pm 0.10)$

$0.30( \pm 0.06)$

$0.32( \pm 0.08)$

$0.35( \pm 0.07)$

Arfth Mean: 0.40
$0.44( \pm 0.08)$
$0.55( \pm 0.11)$
$0.43( \pm 0.09)$
$0.43( \pm 0.09)$
$0.46( \pm 0.09)$
$0.44( \pm 0.09)$
$0.73( \pm 0.14)$
$0.47( \pm 0.10)$
$0.50( \pm 0.10)$
$0.43( \pm 0.09)$
$0.37( \pm 0.07)$
$0.41( \pm 0.08)$
$0.38( \pm 0.08)$
$0.47( \pm 0.09)$
$0.39( \pm 0.08)$
$0.37( \pm 0.09)$
$0.51( \pm 0.10)$

ArIth Mean: 0.46 


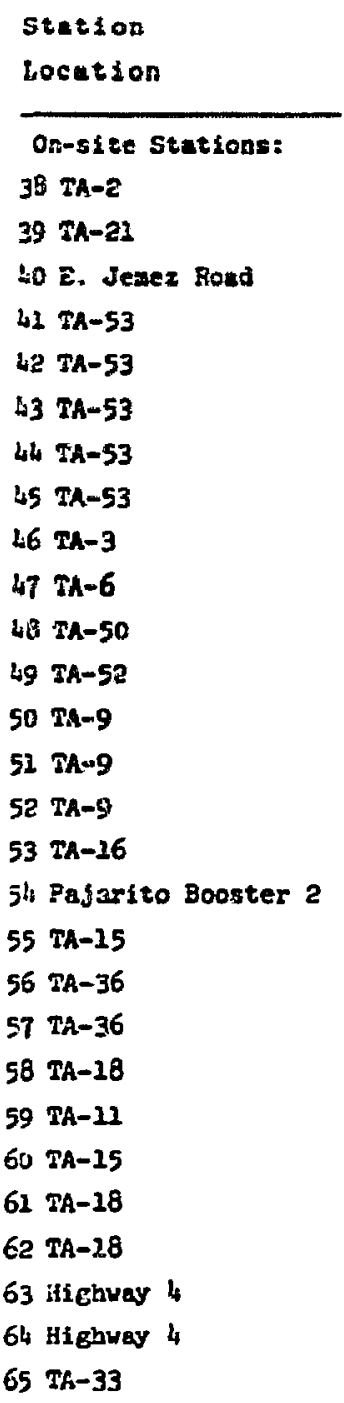

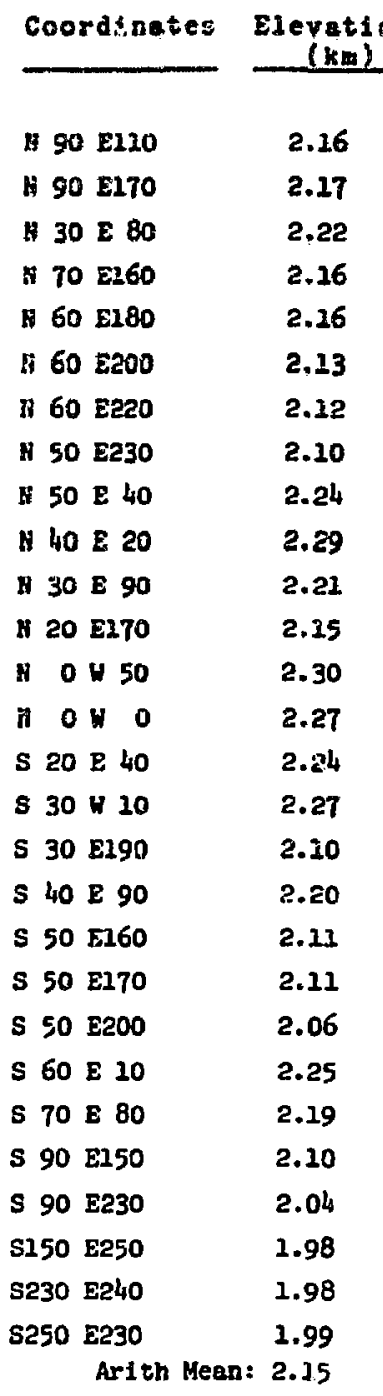

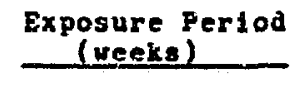

Arerage Done Rate (mrad/day)
4

13

13

13

4

13

13

13

4

13

23

13

13

23

13

13

13

13

1.3

4

4

13

4

13

13

13

13

13

4

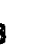

13

3

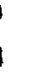

3

3

3

3

3

(1)

(3)

1

$0.45( \pm 0.03)$

$0.33( \pm 0,07)$

$0.43( \pm 0.09)$

$0.38( \pm 0.07)$

$0.39( \pm 0.07)$

$0.50( \pm 0.10)$

$0.65( \pm 0.13)$

$0.53( \pm 0.11)$

$0.35( \pm 0.07)$

$0.39( \pm 0.08)$

$0.37( \pm 0.08)$

$0.35( \pm 0.07)$

$0.47( \pm 0.10)$

$0.45( \pm 0.10)$

$0.43( \pm 0.09)$

$0 \cdots+0.08$ )

$1 . \pm 3( \pm 0.24)$

$0.43( \pm 0.09)$

$0.53( \pm 0.22)$

$0.90( \pm 0.18)$

$1.73( \pm 0.33)$

$0.40( \pm 0.08)$

$0.48( \pm 0.10)$

$0.45( \pm 0.09)$

$0.47( \pm 0.12)$

$0.46( \pm 0.10)$

$0.55( \pm 0.17$ )

Artth Mean ${ }^{2}: 0.44$

Excluding stations 54,57 , and 58 .

exchanged routincly every week. Two types of air pumps, with flow rates of approximately 1 and $3 \mathrm{l} / \mathrm{s}$, were used in the network. Atmospheric aerosol was collected on a 79-mm-diam polystyrene filtcr which was supported on a Welsh activated-charcoal respirator cartridge between the cartridge prefilter and the louvered polyethylene cover. A fraction of the total air flow $(\approx 1 \mathrm{ml} / \mathrm{s})$ was passed in parallel through a cartridge containing silica gel to adsorb atmospheric water vapor. Air flow rates through both sampling cartridges were monitored with variable-area flowmet .rs.
Appendix D contains a listing of concentration guides (CGs) for several radioactive species in air and water for uncontrolled and controlled areas. Referring to Fig. 3 and Table IV, monitoring stations 1 through 17, 20, 21, 23, and 26 are outside the LASL boundary, and concentrations for these locations are compared to CGs for uncontrolled areas. All other stations in Table IV, however, are within the LASL boundary where the CGs for controlled areas apply. 
TABLE III

\section{ANNUAL EXTERNAL DOSE ANALYSIS}

\begin{tabular}{|c|c|c|c|c|c|c|c|c|}
\hline \multirow{3}{*}{$\begin{array}{l}\text { Monitored } \\
\text { Lacetions }\end{array}$} & \multirow{3}{*}{$\begin{array}{l}\text { No. of } \\
\text { Stations }\end{array}$} & \multirow{3}{*}{$\begin{array}{l}\text { Avg } \\
\text { Elev } \\
\text { (km) }\end{array}$} & \multicolumn{6}{|c|}{ Annual Dose (mrad) } \\
\hline & & & \multirow[b]{2}{*}{ Min } & \multirow[b]{2}{*}{ Mex } & \multicolumn{2}{|c|}{ Arithmetic } & \multicolumn{2}{|c|}{ Geometric } \\
\hline & & & & & Mean & Sta Dev & Mean & Std Dev \\
\hline off-site, all & 20 & 2.06 & 110 & 226 & 145 & 29 & 142 & 1.2 \\
\hline Off-site, all above $2 \mathrm{~km}$ & 11 & 2.24 & 117 & 226 & 153 & 29 & 150 & 1.2 \\
\hline Off-site, all below $2 \mathrm{~km}$ & 9 & 1.83 & 110 & 193 & 135 & 26 & 135 & 1.2 \\
\hline Perimeter, all & $2 \pi$ & 2.15 & 133 & 265 & 167 & 31 & 165 & 1.2 \\
\hline Perimeter, excluding $\| 27^{\mathrm{b}}$ & 16 & 2.16 & 133 & 201 & 161 & 19 & 161 & 1.1 \\
\hline On-site, all & 28 & 2.15 & 120 & 632 & 193 & 105 & 178 & 1.4 \\
\hline On-site, excluding 3 highest ${ }^{c}$ & 25 & 2.16 & 120 & 238 & 162 & 26 & 160 & 1.2 \\
\hline Los Alamos Community & 11 & 2.22 & 117 & 226 & 155 & 28 & 153 & 1.2 \\
\hline
\end{tabular}

ane eeometric standard devietion $\sigma_{\mathrm{g}}$ is a unitless, multiplicative number.

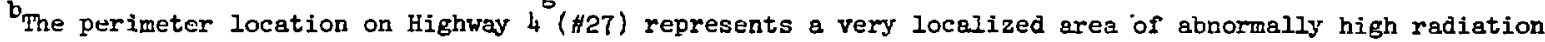
intensity.

CThe manitoring stations at Pajarito Booster 2 (\$54), TA-36 (\#57) and TA-18 (\#58) are influenced by operations at TA-18.

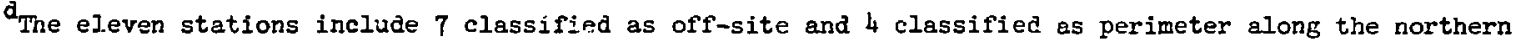
boundary of the Laboratory.

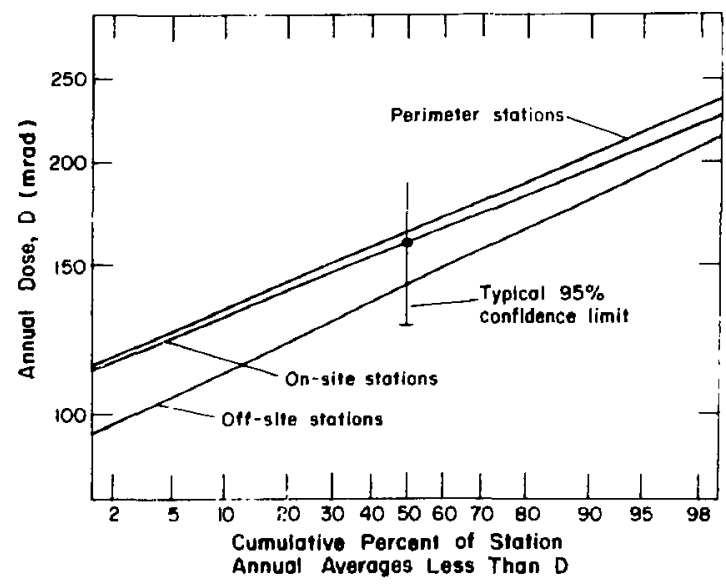

Fig. 4.

Log-normal probability distributions of TLD data.

\section{B. Daily Radioactivity Sampling}

Atmospheric radioactivity was measured daily at TA-50, N 30 E 90, with a particulate sampling system similar to those used in the weekly sampling. A daily deposition sample was collected simultaneously with a $0.4-\mathrm{m}^{2}$ precipitation sampler.

The daily particulate filter was counted for gross alpha and gross beta on the day of collection and again 7 to 10 days after collection. The first count would provide an early indication of any major unpredicted radioactivity release. The data from the second count were used to observe temporal variations in the long-lived radioactivity. The gross alpha and gross beta radioactivity measurements for the daily deposition sample were made on the same schedule as that of the daily particulate sample, but they were not routinely reported. The gross alpha activity data for the daily particulate samples are not presented because they did not generally exceed the MDL for this measurement.

Gross beta activity data from the second count of the daily particulate sample are shown in Fig. 5. The seasonal variations for 1973 are noteworthy and atypical of expected trends; the beca activity for 1973 was relatively low, and the characteristic spring maximum was absent. An increase in activity for December is also anomalous. However, the observed trends were confirmed by preliminary data reported for the Nevada Test Site, suggesting a 
TABLE IV

\section{ANNUAL ATMOSPHERIC TRITIATED WATER VAPOR AND URANIUM CONCENTRATIONS}

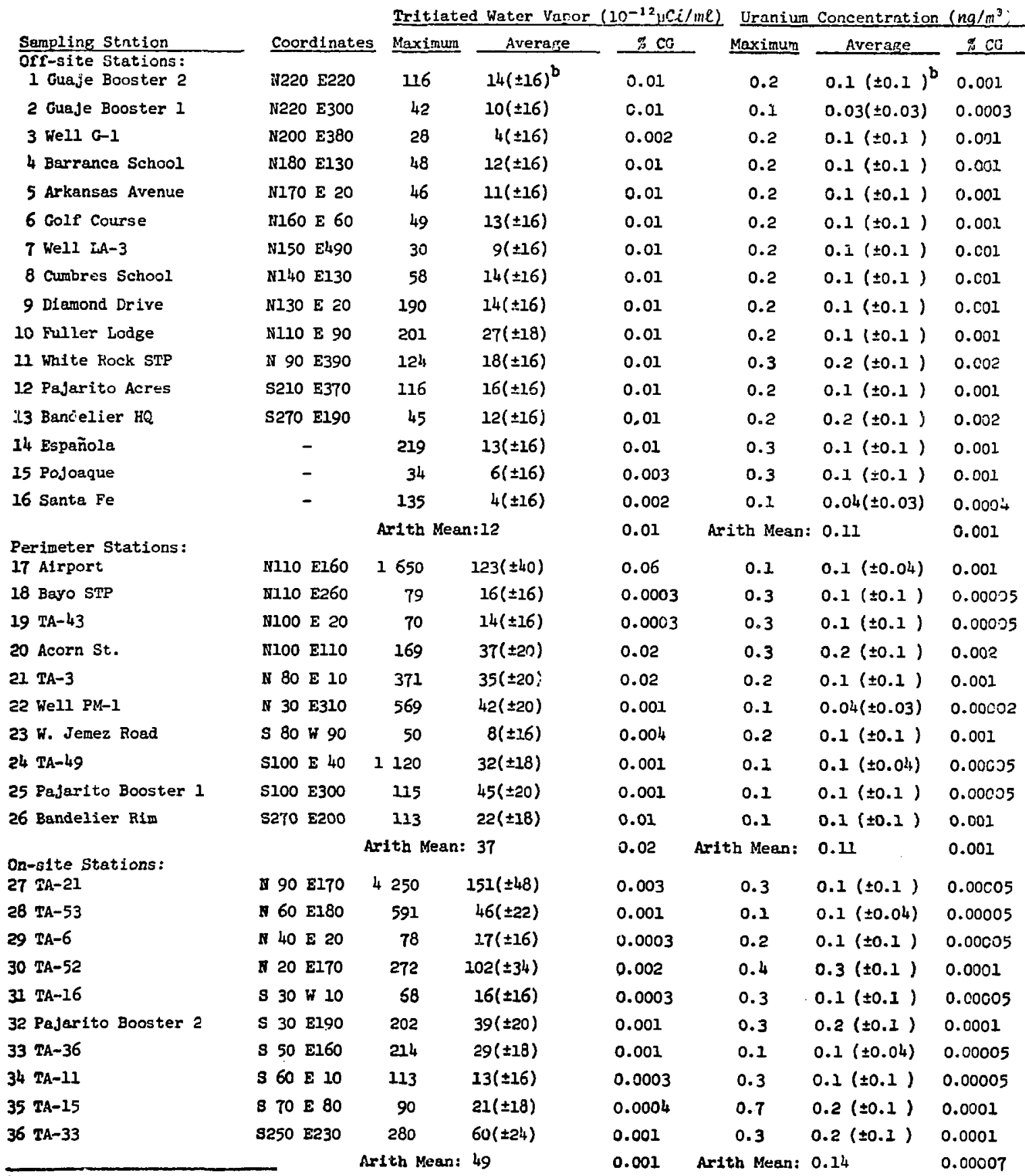

Converted from concentration in water vapor to totel atmospheric concentration based on relative humidity.

Velues in parentheses indicate $95 \%$ confidence limits ( \pm 2 S.D.): 
$\mp$

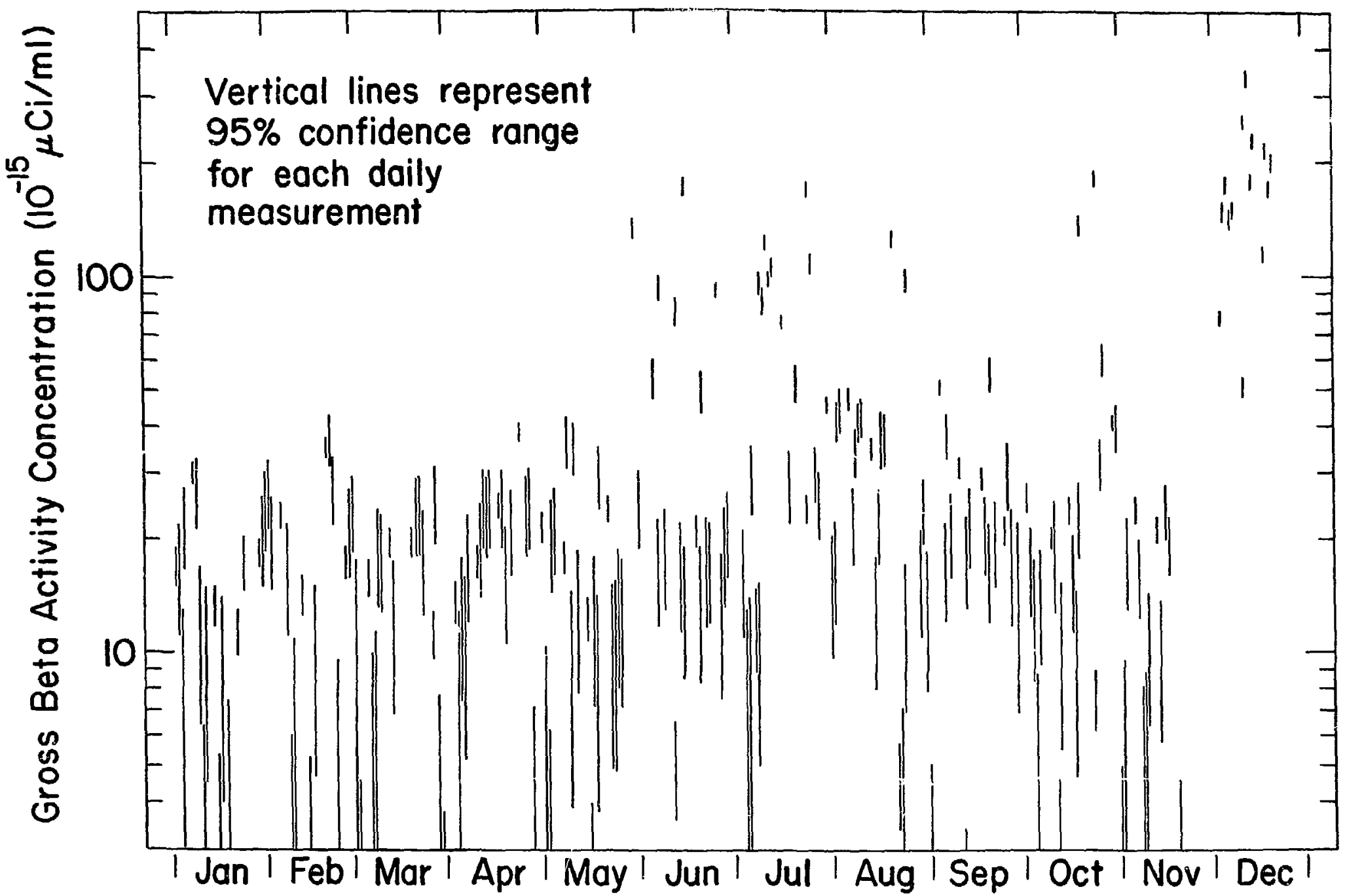

Fig. 5.

Gross beta activity concentrations in daily air samples. 
more general metcorological pattern. Our atmospheric radioactivity data did not show evidence of foreign atmospheric nuclear tests.

\section{Tritium}

Thirty-six silica gel cartridges were analyzed each w..k for tritiated water. Water was distilled from each silica gel sample, and a standard aliquot of the distillate was analyzed for tritium by liquid scintillation counting. The resultant tritium activity concentration in water was then multiplied by the average absolute humidity (mass water/ volume air) for the samplc collection period to give the average tritiated water vapor activity concentration in air.

The weekly activity concentrations for each station were averaged for CY 73 and are presented in Table IV. Parenthetical values are the $\mathbf{9 5 \%}$ confidence level errors associated with average annual concentrations. The data are grouped according to off-site, perimeter, and on-site sampling locations. The large uncertainties in concentrdtion values at the off-site or "background" stations were due primarily to the fact that most of the values were near the MDL (Appendix C). Certain perimeter and onsite locations, e.g., Airport, TA-21, TA-52, and TA-33, were influenced by LASL tritium releases. The highest observed annual concentration for an off-site area (Airport) was $123 \times 1 \sigma^{12} \mu \mathrm{Ci} / \mathrm{m} \ell$ for the on-site locations, the highest value was $151 \times 10^{-12} \mu \mathrm{Ci} / \mathrm{ml}$, measured at TA-21. These concentrations are, respectively, 0.06 and $0.08 \%$ of the CGs specified in AEC Manual Chapter 0524 for tritium in air. The tritium concentrations reported herein, as well as the CGs, are for atmospheric tritium oxide.

The distribution for the 36 annual tritium concentration averages (Fig. 6 ) is skewed in such a manner that it is amenable to a log-normal statistical treatment. The geometric mean for all stations is $20 \times 10^{-12} \mu \mathrm{Ci} / \mathrm{ml}$ and the geometric std dev (multiplicative) is $\sigma_{\mathrm{g}}=2.3$. By comparison, the arithmetic mean and sid dev are $(30 \pm 33) \times 10^{-12}$ $\mu \mathrm{Ci} / \mathrm{ml}$. Also shown in Fig. 6 is a typical uncertainty associated with the annual average concentration. The 95\% confidence level uncertainty corresponds to about $80 \%$ of the measured value.

\section{Gross Radioactivity}

On the first and tenth day after collection, gross alpha and gross beta activities in the weekly air filters were counted with a gas-flow proportional counter. The first count was used to screen the samples for inordinate levels of radioactivity. The second count, free from the activity

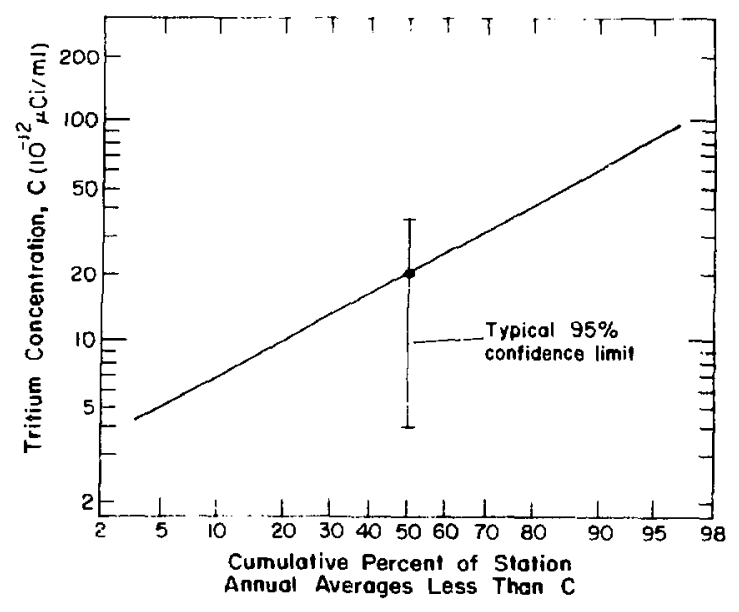

Fig. 6.

Log-normal probability distribution of atmospberic tritium concentrations.

of the radon and thoron daughters, provided a record of the long-lived atmospheric radioactivity. Generally, temporal variations in radioactivity for the weekly stations were similar to those for the daily station shown in Fig. 5. The average weekly gross alpha and gross beta activity concentrations for each station for CY 73 are presented in Table V. Parenthetical values are the $95 \%$ confidence level errors associated with average annual concentrations. The data are grouped according to off-site, perimeter, and onsite sampling locations. For the gross alpha activity, the 36 annual average concentrations are distributed randomly around an arithmetic mean of $1.0 \times 10^{-15} \mu \mathrm{Ci} / \mathrm{m} \ell$ and have a standard deviation of $0.2 \times 10^{-15} \mu \mathrm{Ci} / \mathrm{ml}$. The spatial variation of the annual averages is not related to LASL operations. In fact, the annual average concentrations for off-site stations arc typically higher than those for perimeter and on-site stations (see Table V). The highest gross alpha concentration, observed at Española, is $2.3 \%$ of the CG for an uncontrolled area (Appendix D). For the gross beta activity, the 36 annual average coneentrations are also normally distributed with an arithmetic mean and standard deviation of $(38 \pm 3) \times 10^{-15} \mu \mathrm{Ci} / \mathrm{ml}$, and spatial variations are not related to LASL opcrations. The three location groups have essentially the same annual average concentration mean (see Table V). Each group had a highest observed annual concentration of $43 \times 10^{-15} \mu \mathrm{Ci} / \mathrm{ml}$, which is only $0.14 \%$ of the CG for gross beta activity in an uncontrolled area and $0.004 \%$ of the CG for a controlled area (Appendix D). 
TABLE V

ANNUAL ATMOSPHERIC GROSS ALPHA AND GROSS BETA ACTIVITY CONCENTRATIONS

Sampling Station

\begin{tabular}{|c|c|}
\hline Location & Coordinat \\
\hline \multicolumn{2}{|l|}{ orf-site stations: } \\
\hline I Gugje Booster 2 & N220 E220 \\
\hline 2 Gueje Booster 1 & N220 E300 \\
\hline S well G-1 & $\mathrm{N} 200 \mathrm{E} 380$ \\
\hline 4 Barranca School & N180 $\quad 2130$ \\
\hline 5 Arkansas Ave. & $\$ 170 \Xi 20$ \\
\hline 6 Golf Course & N160 E 60 \\
\hline 7 Hell LA-3 & $N 150 E 490$ \\
\hline 8 Cumbres School & $N \perp 40 E 130$ \\
\hline 9 Diamond Drive & $\mathrm{N} 130=20$ \\
\hline In Fuller Lodge & $\$ 110 \mathrm{E} 90$ \\
\hline 11 White Rock STP & S SO E390 \\
\hline 12 Pajarito Acres & $5210=370$ \\
\hline 13 Bandelier HQ & S270 E190 \\
\hline 14 Española & - \\
\hline 15 Pojoaque & - \\
\hline 26 Sante Fe & - \\
\hline
\end{tabular}

Perimeter Stations:

17 L. A. Airport

18 Bayo STP

19 TA-' 3

20 Acorn St.

21 TA-3

22 WeII $P M-1$

23 H. Jemer Roed

24 TA-49

$25 \mathrm{Paj}$. Booster 1

26 Bandelfer Rim

N110 E160

N110 E260

N100 E 20

NIOC EILO

I 80 E 10

v $30 \quad E 310$

S 80 W490

5100 E 40

S100 E300

S270 E200

On-site Stations:

27 TA-21
$28 \mathrm{TA}-53$
$29 \mathrm{TA}-6$
$30 \mathrm{TA}-52$
$31 \mathrm{TA}-16$
$32 \mathrm{Tej} \cdot \mathrm{B}$. 6 ster 2
$33 \mathrm{TA}-36$
$34 \mathrm{TA}-11$
$35 \mathrm{TA}-15$
$36 \mathrm{TA}-33$

N 90 E170

ฟ 60 E180

II 40 E 20

N 20 ELTO

s 30 W 10

s 30 E190

S 50 E160

S $60 \mathrm{E} 10$

B 70 E 80

$\$ 250 \mathrm{E} 230$

Gross Alpha Concentrations $\left(10^{-15} \mathrm{HCi} / \mathrm{m} \ell\right)$ Gross Beta Concentrations $\left(10^{-15}, \mathrm{Cl} / \mathrm{nl}\right)$

\begin{tabular}{|c|c|c|c|c|c|}
\hline Max:mum & Averaze & $\pi \mathrm{CC}$ & Maximum & Averape & $\underline{3 C G}$ \\
\hline 2.6 & $1.3( \pm 0.5)$ & 2.2 & 111 & $39( \pm 7)$ & 0.13 \\
\hline 1.1 & $0.7( \pm 0.4)$ & 1.2 & 74 & $32( \pm 6)$ & 0.11 \\
\hline 2.3 & $1.3( \pm 0.4)$ & 2.2 & 127 & $39( \pm 7)$ & 0.13 \\
\hline 1.9 & $1.0( \pm 0.4)$ & 1.7 & 127 & $39( \pm 7)$ & 0.13 \\
\hline 2.0 & $1.0( \pm 0.4)$ & 1.7 & 39 & $39( \pm 7)$ & 0.13 \\
\hline 2.6 & $1.2( \pm 0.4)$ & 2.0 & 91 & $40( \pm 7)$ & 0.13 \\
\hline 2.3 & $1.2( \pm 0.4)$ & 2.0 & 127 & $43( \pm 8)$ & 0.14 \\
\hline 3.4 & $1.3( \pm 0.4)$ & 2.2 & 116 & $41( \pm 7)$ & 0.14 \\
\hline 4.1 & $1.3( \pm 0.4)$ & 2.2 & 151 & $38( \pm 7)$ & 0.13 \\
\hline 2.9 & $1.2( \pm 0.4)$ & 2.0 & 164 & $42( \pm 8)$ & 0.14 \\
\hline 2.6 & $1.3( \pm 0.4)$ & 2.2 & 85 & $41( \pm 7)$ & 0.14 \\
\hline 2.9 & $1.0( \pm 0.4)$ & 1.7 & 85 & $38( \pm 7)$ & 0.13 \\
\hline 2.2 & $1.2( \pm 0.4)$ & 2.0 & 87 & $41( \pm 7)$ & 0.14 \\
\hline 3.1 & $1.4( \pm 0.4)$ & 2.3 & 85 & $41( \pm 7)$ & 0.14 \\
\hline 3.3 & $1.2( \pm 0.4)$ & 2.0 & 72 & $36( \pm 6)$ & 0.12 \\
\hline $2: 4$ & $0.9( \pm 0.4)$ & 1.5 & 163 & $34( \pm 5)$ & 0.11 \\
\hline \multicolumn{2}{|c|}{ Arith Mean:1.16 } & 1.9 & \multicolumn{2}{|c|}{ Arith Mean: 39} & 0.13 \\
\hline
\end{tabular}

$\begin{array}{ll}1.7 & 0.8( \pm 0.4) \\ 4.1 & 1.1( \pm 0.4) \\ 2.4 & 1.2( \pm 0.4) \\ 1.8 & 0.9( \pm 0.4) \\ 4.4 & 1.2( \pm 0.4) \\ 1.7 & 0.8( \pm 0.4) \\ 1.9 & 0.9( \pm 0.4) \\ 4.4 & 0.9( \pm 0.4) \\ 2.1 & 1.0( \pm 0.4) \\ 2.0 & 1.0( \pm 0.4)\end{array}$

Arith Mean: 0.98

$\begin{array}{ll}1.8 & 0.8( \pm 0.4) \\ 1.5 & 0.9( \pm 0.4) \\ 1.7 & 0.9( \pm 0.4) \\ 2.8 & 0.9( \pm 0.4) \\ 4.0 & 1.1( \pm 0.4) \\ 2.0 & 1.2( \pm 0.4) \\ 1.8 & 0.7( \pm 0.4) \\ 2.0 & 1.1( \pm 0.4) \\ 3.3 & 0.8( \pm 0.4) \\ 2.3 & 1.1( \pm 0.4) \\ \text { Ar1th Meen: } 0.95\end{array}$

$\begin{array}{lrrl}1.3 & 80 & 32( \pm 6) & 0.11 \\ 0.06 & 138 & 43( \pm 8) & 0.004 \\ 0.06 & 180 & 43( \pm 8) & 0.004 \\ 1.5 & 39 & 38( \pm 7) & 0.13 \\ 2.0 & 142 & 40( \pm 7) & 0.13 \\ 0.04 & 110 & 36( \pm 6) & 0.004 \\ 1.5 & 85 & 37( \pm 7) & 0.12 \\ 0.05 & 77 & 34( \pm 6) & 0.003 \\ 0.05 & 90 & 40( \pm 7) & 0.004 \\ 1.7 & 86 & 39( \pm 7) & 0.13 \\ 1.6 & \text { Arith Mean: } 38 & 0.13\end{array}$

$\begin{array}{lrrr}0.04 & 77 & 36( \pm 6) & 0.004 \\ 0.05 & 95 & 35( \pm 6) & 0.004 \\ 0.05 & 131 & 37( \pm 7) & 0.004 \\ 0.05 & 91 & 36( \pm 6) & 0.004 \\ 0.06 & 134 & 42( \pm 7) & 0.004 \\ 0.06 & 85 & 37( \pm 7) & 0.004 \\ 0.04 & 78 & 34( \pm 6) & 0.003 \\ 0.06 & 128 & 43( \pm 8) & 0.004 \\ 0.04 & 81 & 33( \pm 6) & 0.003 \\ 0.06 & 88 & 42( \pm 7) & 0.004 \\ 0.05 & \text { Ar1th Mean:38 } & 0.004\end{array}$




\section{E. Plutonium and Americium}

After being measured for gross alpha and gross beta activities, the weekly filters for each station were combince and dissolved to produce composite 4-ivk samples for each station. An aliquot of each sample was saved for uranium analysis, and plutonium was separated by anion exchange from the remaining solution. For 12 selected stations, the eluent solutions from the plutonium separation were combined to represent 13-wk samples. Americium was then separated from these twelve 13 -wk samples via cation exchange. The purified plutonium and americium were separately electrodeposited and counted for alpha-particle emission with a solid-state alphadetection system. Alpha-particle energy groups associated with the decay of ${ }^{238} \mathrm{Pu},{ }^{239} \mathrm{Pu}$, and ${ }^{241} \mathrm{Am}$ were then integrated, and the concentration of each radionuclide in its respective air sample was calculated.

The annual average 4.wk ${ }^{238} \mathrm{Pu}$ and ${ }^{239} \mathrm{Pu}$ concentrations for each station are listed in Table VI according to off-site, perimeter, and on-site sampling locations. Parenthetical values are the 95\% confidence level errors associated with average annual concentrations. For both ${ }^{238} \mathrm{Pu}$ and ${ }^{239} \mathrm{Pu}$, the asymmetric distributions of annual average concentrations can be described lognormally, as shown in Fig. 7. The range of values observed for the 36 stations, and typical uncertaintics associated with the observed annual average ${ }^{238} \mathrm{Pu}$ and ${ }^{239} \mathrm{Pu}$ concentrations, are shown in Fig. 7 . In both cases, the 95\% confidence level uncertaintics are about $20 \%$ of the observed values. For ${ }^{238} \mathrm{Pu}$ annual concentrations, the geometric mean for all stations is $9 \times 10^{-18} \mu \mathrm{Ci} / \mathrm{ml}$ and $\sigma_{\mathrm{g}}$ is 2.3. The geometric means (sce Table VI) for each of the three location groups are comparable, suggesting no major spatial variation in ${ }^{238} \mathrm{Pu}$ concentration. However, increased concentrations at TA-3 and Fuller Lodge, for example, apparently result from LASL operations. The highest observed annual concentration, at TA-3, is $0.12 \%$ of the CG for an uncontrolled area (Appendix D). The trends observed for ${ }^{239} \mathrm{Pu}$ concentrations are similar to those observed for ${ }^{238} \mathrm{Pu}$. The geometric mean of annual average ${ }^{239} \mathrm{Pu}$ concentrations for all stations is $17 \times 10^{-18}$ $\mu \mathrm{Ci} / \mathrm{m} \ell$ and $\sigma_{\mathrm{g}}$ is 1.8 . The geometric means for the location groups (Table VI) do not suggest significant spatial variation for ${ }^{239} \mathrm{Pu}$ concentration. The highest annual concentrations, observed at Arkansas Avc. and TA-3, arc $0.09 \%$ of the $\mathrm{CG}$ for ${ }^{239} \mathrm{Pu}$ in an uncontrolled area (Appendix D).

The annual average $13-\mathrm{wk}^{241}$ Ann concentrations for each of the 12 selected stations are shown in Table VI. Not only is there a wide variation in the data, but the $95 \%$ confidence level uncertainties associated with the concentrations are high. Therefore, no attempt was made to analyze the ${ }^{241} \mathrm{Am}$ data statistically as was done for ${ }^{238} \mathrm{Pu}$ and ${ }^{239} \mathrm{Pu}$. The highest observed annual average concentration of ${ }^{241} \Lambda \mathrm{m}$ was $0.01 \%$ of the $C G$ for an uncontrolled area (Appendix D).

\section{F. Uranium}

For each of the 36 stations, an air-filter sample was composited with aliquots from the plutonium-americium procedurc to represent a 13-wk sampling period. The uranium content of the sample was determined by fluorometric techniques to obtain quarterly atmospheric uranium concentrations. The 13-iwk annual averages for each station are listed in Table IV. The fluorometric analysis, of course, does not differentiatc isotopes of uranium, and the annual average concentracions are given in $\mathrm{ng} / \mathrm{m}^{3}$. The concentration values in general do not exceed the MDL for the neasurcment and are not amenable to statistical analysis. The highest observed annual concentration of $0.3 \mathrm{ng} / \mathrm{m}^{3}$, at $\mathrm{TA}-52$, is $0.0001 \%$ of the $\mathrm{CG}$ for natural uranium in a controlled arca (Appendix D). Although the isotcpic composition of the uranium is unknown, the total uranium in LASL relcase is not drastically different from natural uranium in isotopic composition.

\section{G. Summary}

Table VII summarizes the results of the atmospheric radioaetivity monitoring program for CY 73 .

\section{R'DIOACTIVITY IN SURFACE AND GROUND WATERS}

\section{A. Overview}

The monitoring of radioactivity in surface and ground waters provides surveillance of LASL operacions. Water samples were obtained from a network which includes (a) regional water sources within $75 \mathrm{~km}$ of LASL, (b) perimeter sources within $5 \mathrm{~km}$ of the LASL boundary, (c) Los Alames water supply system, and (d) LASL onsite sources. The water samples werc analyzed radiochemically for ${ }^{238} \mathrm{Pu},{ }^{239} \mathrm{Pu}$, tritium (HTO), and ${ }^{137} \mathrm{Cs}$ activities as well as for gross alpha, beta, and gamma activities. A fluorometric technique was used to measure uranium concentrations. Americium-241 was determined radiochemically for selected samples from LASL effluent relcase areas. 
TABLE VI

ANNUAL ATMOSPHERIC ${ }^{238} \mathrm{Pu},{ }^{239} \mathrm{Pu}$, AND ${ }^{241}$ Am CONCENTRATIONS

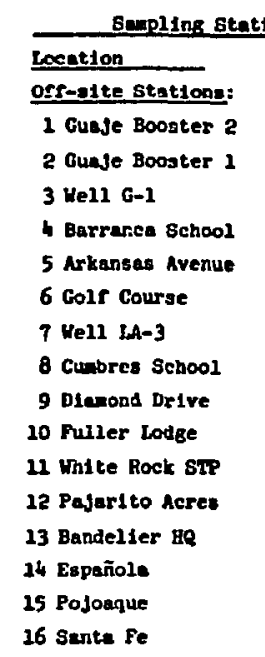

\section{Perineter Stetione:}

17 L. A. Alrport

18 Bayo STP

$19 \mathrm{TA}-43$

20 Acoen St.

21 TA-3

23 H. Jenez Roud

24 2a-4a

25 Pujurlto Booster 1

26 Bandelier Bis

\section{On-site stations:}

\begin{tabular}{|c|c|}
\hline $27 T A-21$ & ก $90 \mathrm{E} 170$ \\
\hline $28 \mathrm{I} A-53$ & I $60 \mathrm{E} 180$ \\
\hline 29 TA-6 & N $40 \mathrm{E} 20$ \\
\hline $30 \mathrm{TA}-52$ & * $20 \mathrm{E} 170$ \\
\hline $31 \mathrm{TA}-\mathrm{i} 6$ & B $30 * 10$ \\
\hline 32 Pajarito Booster 2 & B $30 \quad 8190$ \\
\hline $332 A-36$ & B $50 \mathrm{E} 160$ \\
\hline $34 \quad 2 A-12$ & S 60 E 10 \\
\hline $35 \tau a-15$ & $670 \mathrm{E} 80$ \\
\hline $36 \mathrm{Th}-33$ & 82502230 \\
\hline
\end{tabular}

\begin{tabular}{|c|c|c|}
\hline m10 E160 & 177 & $19( \pm 3)$ \\
\hline M110 B260 & 31 & $9( \pm 3)$ \\
\hline$\$ 100$ \& 20 & 73 & $21( \pm 5)$ \\
\hline$M 100 \mathrm{E110}$ & 45 & $10( \pm 3)$ \\
\hline$\triangle 80 \mathrm{E} 10$ & 659 & $86( \pm 16)$ \\
\hline A $30 \mathrm{E310}$ & 22 & $5( \pm 1)$ \\
\hline $380 \cup 90$ & 13 & $5( \pm 2)$ \\
\hline 8100 E 40 & 23 & $6( \pm 2)$ \\
\hline$B 1008300$ & 70 & $10( \pm 8)$ \\
\hline \multirow[t]{2}{*}{8270 E200 } & 9 & $4( \pm 2)$ \\
\hline & Arith & 18 \\
\hline
\end{tabular}

0.03

0.0005

0.001

0.02

0.12

0.0003

0.01

0.0003

0.0005

0.01

0.03

31

10

$7( \pm 2)$

0.0004

$3( \pm 1) \quad 0.0002$

$14( \pm 3)$

0.0007

$7( \pm 2)$

$10( \pm 3)$

$30( \pm 6)$

$6( \pm 1)$

$7( \pm 2)$

$6( \pm 2)$

$6( \pm 2)$

Arith Mean: 10

0.0004

0.0005

0.002

0.0003

0.0004

0.0003

0.0003

0.0005
22 Nell PH-1

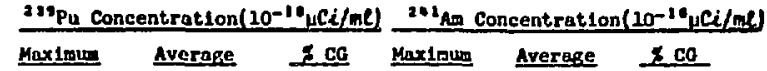

$68 \quad 29( \pm 7) \quad 0.05$

$27 \quad 10( \pm 2) \quad 0.02$

$31 \quad 13( \pm 4) \quad 0.02$

$482 \quad 54( \pm 40) \quad 0.09$

$395 \quad 5 h( \pm 10) \quad 0.09$

$14( \pm 3) \quad 0.02$

$11( \pm 3) \quad 0.02$

$46( \pm 9) \quad 0.08$

$17( \pm 4) \quad 0.03$

$20( \pm 4) \quad 0.03$

$14( \pm 3) \quad 0.02$

9( \pm 2$) \quad 0.02$

$10( \pm 2) \quad 0.02$

$10( \pm 2) \quad 0.02$

$10( \pm 2) \quad 0.02$

$8( \pm 2) \quad 0.02$

$139 \quad 26( \pm 5) \quad 0.01$

$\begin{array}{lll}6 & 5( \pm 2) & 0.002\end{array}$

$52( \pm 5) \quad 0.001$

$\begin{array}{lll}7 & 5( \pm 4) & 0.002\end{array}$

$(20)$

$4 \quad 4( \pm 1) \quad 0.002$

Ar1th Mean:21 0.04

$\begin{array}{rrlrll}186 & 44( \pm 7) & 0.07 & & & \\ 68 & 28( \pm 5) & 0.001 & 3 & 3( \pm 3) & 0.00005 \\ 135 & 31( \pm 6) & 0.002 & & & \\ 118 & 28( \pm 5) & 0.05 & 9 & 4( \pm 1) & 0.002 \\ 221 & 53( \pm 10) & 6.09 & 11 & 7( \pm 3) & 0.004 \\ 57 & 13( \pm 3) & 0.0007 & & & \\ 129 & 26( \pm 5) & 0.4 .5 & & & \\ 69 & 13( \pm 3) & 0.0007 & & & \\ 37 & 13( \pm 6) & 0.0007 & & & \\ 37 & 10( \pm 2) & 0.02 & & & \\ \text { Arith Moan: } 26 & 0.04 & & & \end{array}$

Arith Moan: 26

The plutonium analyses performed on these samples deserve special mention. Plutonium concentrations reported for many of the sampling stations are highly suspect because there exists a cross-contamination and/or effluent-contamination problem in the analytical laboratory. Plutonium concentrations are reported, however, even though they may not be representative of the actual

$\begin{array}{rrllll}59 & 16( \pm 3) & 0.0008 & & & \\ 18 & \theta( \pm 2) & 0.0004 & 2 & 2( \pm 1) & 0.00003 \\ 82 & 24( \pm 9) & 0.001 & & & \\ 104 & 12( \pm 2) & 0.0006 & & & \\ 83 & 18( \pm 4) & 0.0009 & 4 & 3( \pm 2) & 0.00005 \\ 77 & 20( \pm 4) & 0.001 & 23 & 12( \pm 3) & 0.0002 \\ 60 & 16( \pm 3) & 0.0008 & & & \\ 53 & 16( \pm 4) & 0.0008 & & & \\ 33 & 10( \pm 2) & 0.0005 & 4 & 2( \pm 1) & 0.00003 \\ 27 & 11( \pm 3) & 0.0006 & & & \\ \text { Axith Hean: } 15 & 0.0008 & & & \end{array}$

contamination in the sampled waters. Efforts are being made to eliminate these analysis contaminations.

\section{B. Regional Surface Waters}

Streams and reservoirs within about $75 \mathrm{~km}$ of LASL were sampled routinely to ascertain normal levels of 


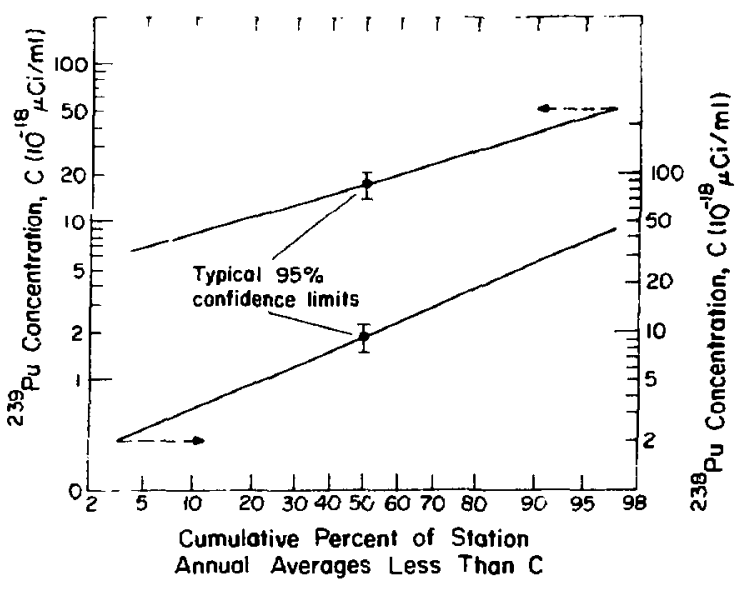

Fig. 7.

Log-normal probability distributions of airborne plutonium concentrations.

radioactivity in waters of the area. Locations of the regional sampling stations are given in Table VIII and Fig. 8. The radioactivity concentration ranges and averages determined for 19 samples are given in Table IX. Plutonium-238 concentrations for Embudo, 120 ( \pm 50 ), and Jemez Creek, $70( \pm 30) \times 1 \sigma^{-12} \mu \mathrm{Ci} / \mathrm{ml}$, as well as ${ }^{239} \mathrm{Pu}$ concentrations for Chamita, $210( \pm 70)$, Embudo, $690( \pm 120)$, Otowi, $820( \pm 140)$, Cochiti, $590( \pm 120)$, Fenton Lake $210( \pm 70)$, and Santa Cruz Reservoir, 190 $( \pm 80) \times 1 \sigma^{-12} \mu \mathrm{Ci} / \mathrm{m} \ell$ were suspect. These levels exceed concentrations expected from global fallout, yet it is highly improbable that they resu'ted from LASL operations. Contamination of the samples during analysis is a more realistic explanation. All other data fall within expected ranges for background radioactivity concentrations, and all concentrations were well below the CGs given in Appendix $D$.

\section{Perimeter Surface and Ground Waters}

Samples were collected from perimeter surface and ground water sources located $\$ 5 \mathrm{~km}$ outside the LASL boundary. Six of these stations are located on the Pajarito Plateau and 24 are in White Rock Canyon (exact locations are given in Table VIII and Figs. 9 and 10). Radioactivity concentration data for 40 perimeter samples are presented in Table IX. Again, certain anomalous plutonium concentrations probably result from contamination in the analytical laboratory. In all cases, concentrations were well below CGs.

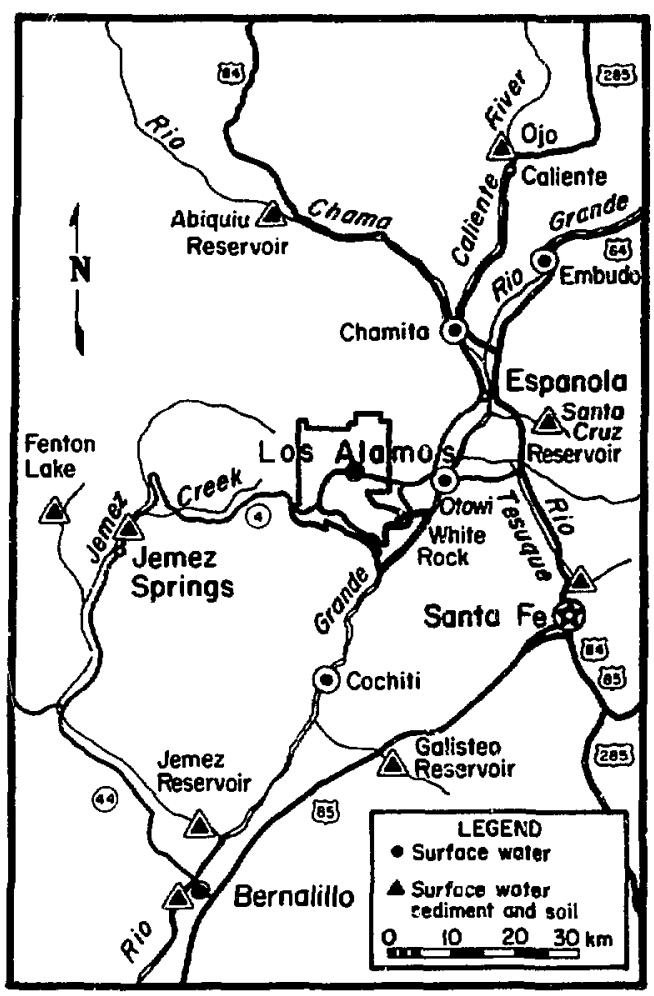

Fig. 8.

Regional surface water, sediment, and soil sampling locations.

\section{Los Alamos Water Supply System}

Radioactivity concentrations were determined for the 16 wells and 1 gallery of the Los Alamos water supply system. The locations of these stations are given in Table VIII and Fig. 10. Plutonium-239 was detected in the trace amounts, $120( \pm 70), 110( \pm 50)$, and $120( \pm 90) \times 10^{-12}$ $\mu \mathrm{Ci} / \mathrm{ml}$, in samples from wells $\mathrm{LA}-1 \mathrm{~B}, \mathrm{LA}-4$, and $P M-2$, respestively. However, average plutonium concentrations are comparable to the minimum detection limits of the analyses. The radioactivity concentration data for 33 samples are presented in Table IX. In all cases, concentrations were well below CGs.

\section{E. On-Site Surface and Ground Waters}

Radioactivity concentrations were determined in water samples from five on-size locations that are not Laboratory effluent release areas. In addition, samples were 
TABLE VII

\section{SUMMARY OF ANNUAL, ATOMSPHERIC RADIOACTIVITY MONITORING}

\begin{tabular}{|c|c|c|c|c|c|c|}
\hline $\begin{array}{l}\text { Number and } \\
\text { Type of Samp- } \\
\text { iing Locations }\end{array}$ & $\begin{array}{l}\text { Type of } \\
\text { Analysis } \\
\text { Performed }\end{array}$ & $\begin{array}{l}\text { Time Period } \\
\text { per Composite } \\
\text { Sample }\end{array}$ & $\begin{array}{l}\text { Number of } \\
\text { Samples } \\
\text { Analyzed }\end{array}$ & $\begin{array}{l}\text { Radi } \\
\text { Cono }\end{array}$ & $\begin{array}{l}\text { Mean } \\
\text { ioactivity } \\
\text { centration }\end{array}$ & $\operatorname{gCG}$ \\
\hline 16 off-site & & & 797 & 1.2 & $10^{-15_{2} \mathrm{Ci} / \mathrm{ml}}$ & 1.9 \\
\hline 10 perimeter & gross a & 1 week & 516 & 1.0 & $10^{-1} \mathrm{~s}_{\mu \mathrm{Ci}} / \mathrm{m \ell}$ & 1.6 \\
\hline 10 on-site & & & 534 & 3.0 & $10^{-15} \mu \mathrm{Ci} / \mathrm{ml}$ & 0.05 \\
\hline 16 off-site & & & 807 & 39 & $10^{-15} \mu \mathrm{Ci} / \mathrm{ml}$ & 0.13 \\
\hline 10 perimeier & Gross B & 1 week & 516 & 38 & $10^{-15} \mu \mathrm{Ci} / \mathrm{ml}$ & 0.13 \\
\hline 10 on-site & & & 511 & 38 & $10^{-15} \mathrm{uCi} / \mathrm{ml}$ & 0.004 \\
\hline 36 off-site & & & 719 & 12 & $10^{-12} \mu \mathrm{Ci} / \mathrm{ml}$ & 0.01 \\
\hline 20 perimeter & tritiated $\mathrm{B}_{2} \mathrm{O}$ & 1 week & 494 & 37 & $10^{-12} \mu \mathrm{Ci} / \mathrm{ml}$ & 0.02 \\
\hline 10 on-site & & & 485 & 49 & $10^{-12} \mu \mathrm{Ci} / \mathrm{mR}$ & 0.001 \\
\hline 16 off-site & & & 189 & 15 & $10^{-18} \mu \mathrm{Ci} / \mathrm{ml}$ & 0.01 \\
\hline 10 perimeter & ${ }^{238_{\mathrm{Pu}}}$ & 1 monti & 119 & 18 & $20^{-18} \mu \mathrm{Ci} / \mathrm{ml}$ & 0.02 \\
\hline 10 on-site & & & 118 & 10 & $10^{-18} \mathrm{uCi} / \mathrm{ml}$ & 0.0004 \\
\hline 16 off-site & & & 189 & 21 & $20^{-18}{ }_{\mu} \mathrm{Ci} / \mathrm{ml}$ & 0.03 \\
\hline I0 perimeter & ${ }^{2}{ }^{39} \mathrm{Pu}$ & I month & 119 & 26 & $20^{-2 \theta} \mathrm{uCi} / \mathrm{ml}$ & 0.04 \\
\hline 10 on-site & & & 118 & 15 & $10^{-18}{ }_{\mu} \mathrm{Ci} / \mathrm{ml}$ & 0.0007 \\
\hline 5 off-site & & & $2 ?$ & 8 & $20^{-18} \mu \mathrm{Cl} / \mathrm{ml}$ & 0.004 \\
\hline 3 perimeter & $241 \mathrm{Am}$ & 3 month & 8 & 5 & $10^{-1 \theta} \mu \mathrm{C} i / \mathrm{ml}$ & 0.002 \\
\hline 4 on-site & & & 12 & 5 & $10^{-18} \mu \mathrm{Ci} / \mathrm{ml}$ & 0.0001 \\
\hline 16 off-site & & & 64 & 0.13 & $1 \mathrm{ng} / \mathrm{m}^{3}$ & 0.001 \\
\hline 10 perimeter & uranium & 3 month & 40 & 0.1 & $1 \mathrm{ng} / \mathrm{m}^{3}$ & 0.001 \\
\hline 20 on-site & & & 40 & 0.1 & $4 \mathrm{ng} / \mathrm{m}^{3}$ & 0.0001 \\
\hline
\end{tabular}

Eor each station, weekly air filters are ccmposited to represent the tabulated sampling period.

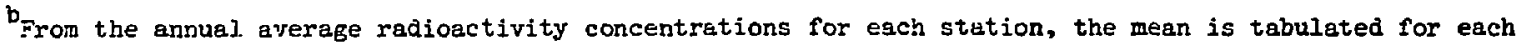
locetion group.

analyzed from 24 locations in past and present Laboratory effluent release areas. Effluent release area samples were obtained from Acid-Pueblo Canyon (formerly LASL, AEC property), Sandia Canyon, DP-Los Alamos Canyon, and Mortandad Canyon. Surface and ground waters in these canyons are not a source of domestic or municipal supply, nor do the streams in these canyons reach the Rio Grande. The on-site water sampling locations are given in Tables VIII and $X$ and Fig. 10. Table $X$ presents the radioactivity concentration data for each location according to non-disposal and effluent areas.

The radioactivity concentrations observed in AcidPueblo Canyon resulted from effluents released in the canyon before 1964. Observations indicated no significant change in radioactivity concentrations compared to previous reporting periods.' The concentrations in Sandia Canyon water were also similar to previous observations, except for one ${ }^{238} \mathrm{Pu}$ concentration of $220( \pm 60) \times 10^{-12}$ $\mu \mathrm{Ci} / \mathrm{m} \ell$ at station SCS-2.

Surface water samples from DP-Los Alamos Canyon reflected the release of industrial effluents from the treatment plant at TA-21. Except for ${ }^{137} \mathrm{Cs}$, all radioactivity in surface waters of DP Canyon was above background concentrations. Los Alamos Canyon observation holes LAO-2, LAO-3, and LAO-4.5, which are below the confluence with DP Canyon, showed observable radioactivity which decreased with downstream distance. The surface and ground waters of Mortandad Canyon gave evidence of 


\section{TABLE VIII}

\section{WATER SAMPLING STATIONS}

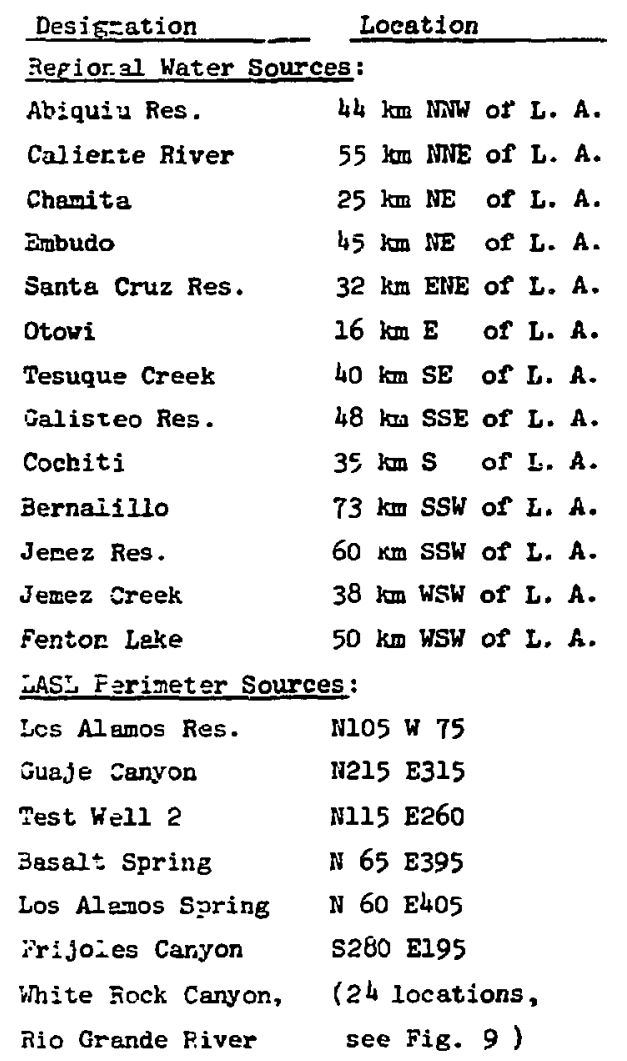

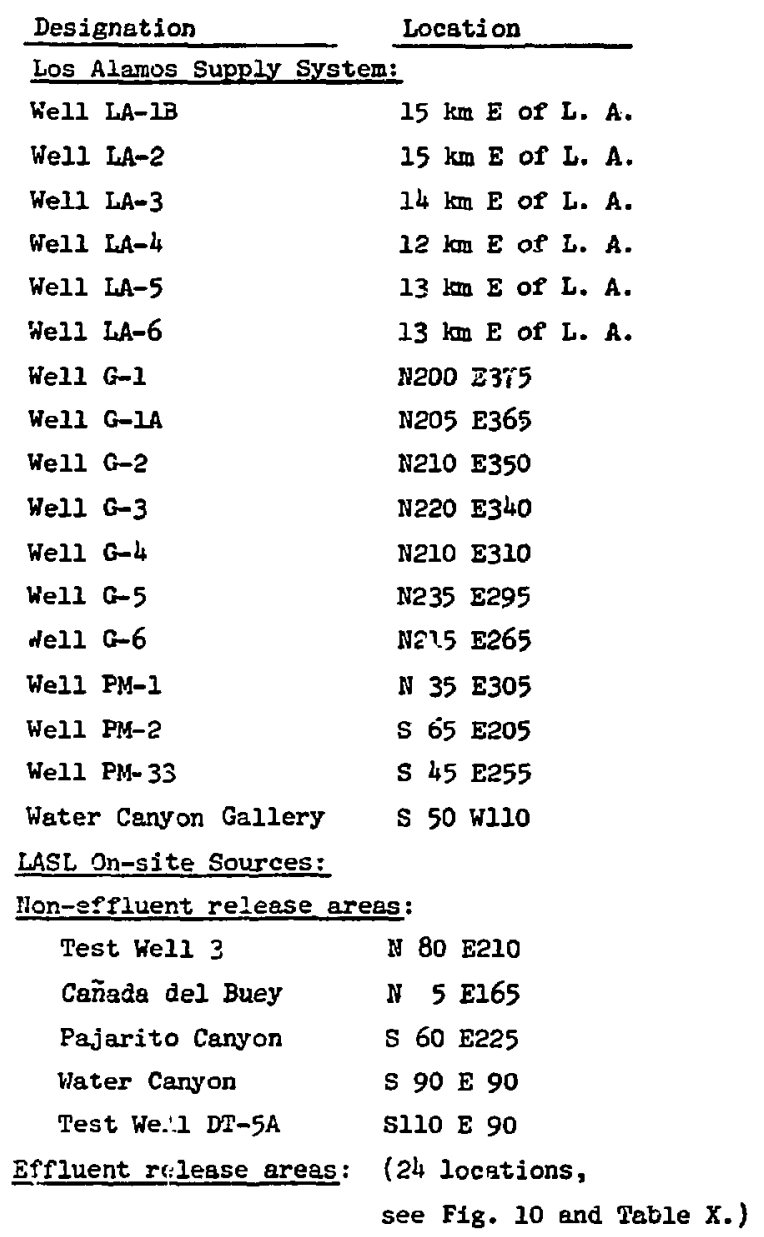

the radioactive effluent released from the industrial waste treatment plant at TA-50. The concentrations of most radionuclides generally decreased with distance down the canyon. Tritium concentrations, however, varied erratically along the length of the canyon.

\section{RADIOACTIVITY IN LIQUID EFFLUENTS, SEDI- MENTS, AND SOILS}

\section{A. Industrial Wastes}

Industrial wastes are collected separately from domestic wastes and treated at one of two plants (TA-21-257 and TA-50-1). The treated wastes are retained in holding tanks until analyzed and are released only when the CGs for release to uncontrolled areas are not exceeded. A composite of each week's total effluents is later analyzed for radioisotopes of concern to determine the total activity of each discharged. The total activity of each isotope and the total volumes discharged were used to calculate the annual average concentrations shown in Table $\mathrm{XI}$.

\section{B. Domestic Wastes}

The effluents from the technical area and municipal sewage plants (Fig. 10) were analyzed for radionuclides twice during 1973. The municipal plants were included to provide background data with which the technical area 
TABLE IX

\section{RADIOACTIVITY IN RECiONAL, PERIMETER, AND LOS ALAMOS WATER SOURCES}

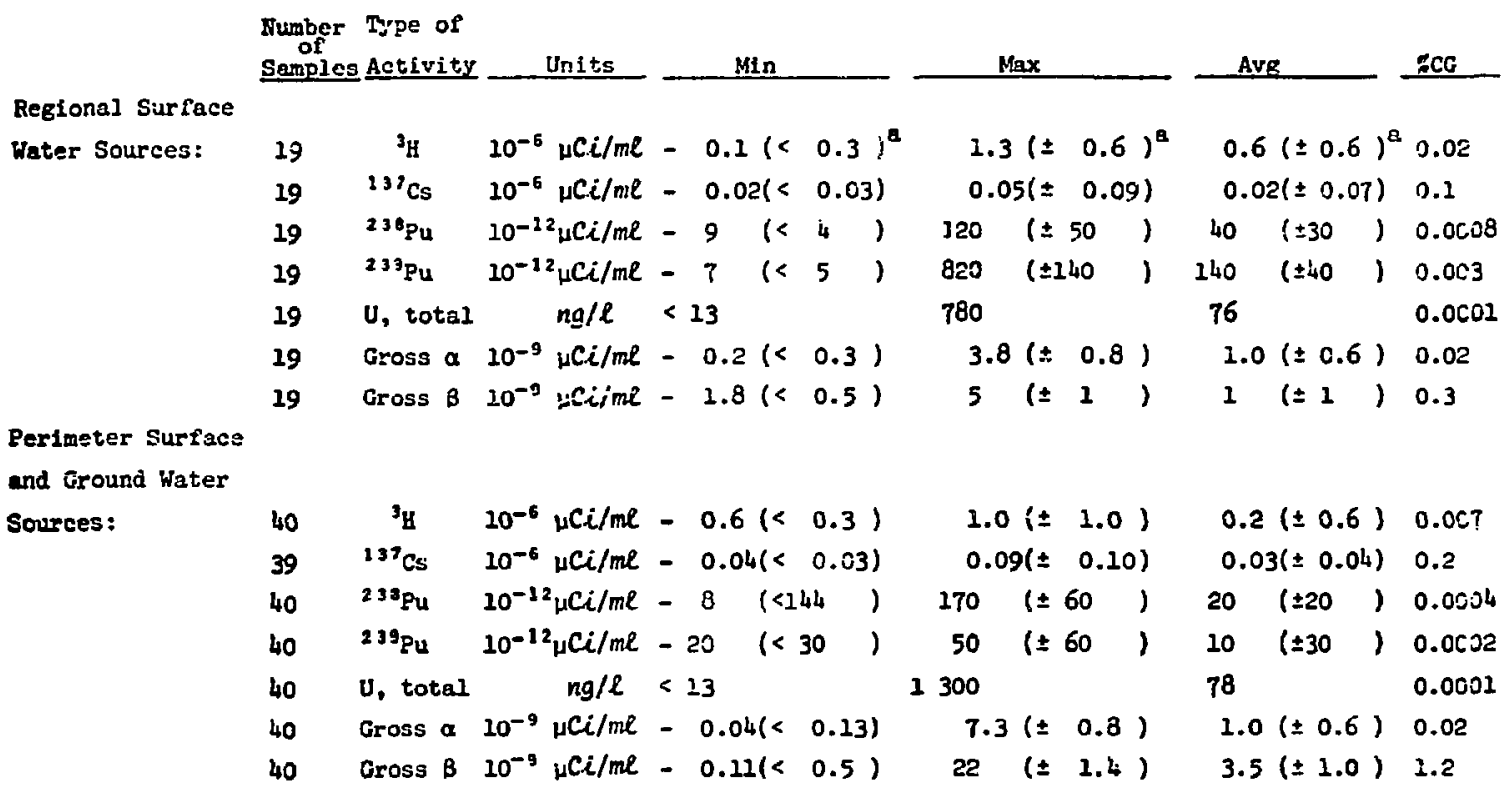

Los Alemos

Noter Supply

Sources:

33
33
33
33
33
33
33

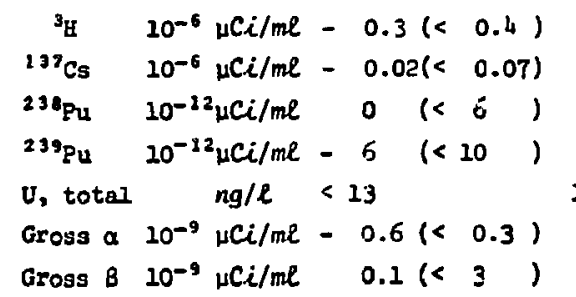

$0.7( \pm 0.8)$
$0.3( \pm 0.1)$
$90( \pm 40)$
$120( \pm 90)$
300
$8( \pm 2 \quad)$
$T( \pm 1)$

$\begin{array}{rll}0.1( \pm 0.8) & 0.003 \\ 0.1( \pm 0.1) & 0.5 \\ 20( \pm 30, & 0.0034 \\ 20 & ( \pm 30, & 0.0004 \\ 80 & & 0.0001 \\ 2( \pm 1, & 0.04 \\ 3 & ( \pm 1, & 1.0\end{array}$

Qulues in brackets represent either (<MD) or ( 2 2 S.D.)

plants' concentrations could be compared. Concentrations in the municipal plant effluents (Table XII) were lower than for the previous year. No previous data are available for the technical area plants.

The plants' influents and effluents were also sampled routinely to detect any accidental release of radioactive wastes to the domistic waste collection system. Samples were collected twice a week and analyzed for gross alpha and gross beta concentrations. No detectable releases occurred during 1973.

Septic tanks at isolated TAs were not sampled, but recently installed sampling boxes will permit sampling of these tanks.

\section{Soil and Sediment Sampling Procedures}

Soil samples were collected by taking five plugs, $75-\mathrm{mm}$ diam and $50 \mathrm{~mm}$ deep, at the center and corners of a 10-m-square area. The five plugs were combined to form a composite sample for radiochemical analysis.

Sediment samples were collected from dune build-up behind boulders in the main channels of perennially flowing streams. Samples from the beds of intermittently flowing streams were collected across the main channel to a depth of $20 \mathrm{~mm}$ with a $75-\mathrm{mm}$-wide scoop.

The soil and sediment samples were analyzed for gross alpha and beta activities, cesium, and plutoniusin. Moisture distilled from the soil samples was analyzed for tritium. 
TABLE X

\section{RADIOACTIVITY IN ON-SITE SURFACE AND GROUND WATER SOURCES}

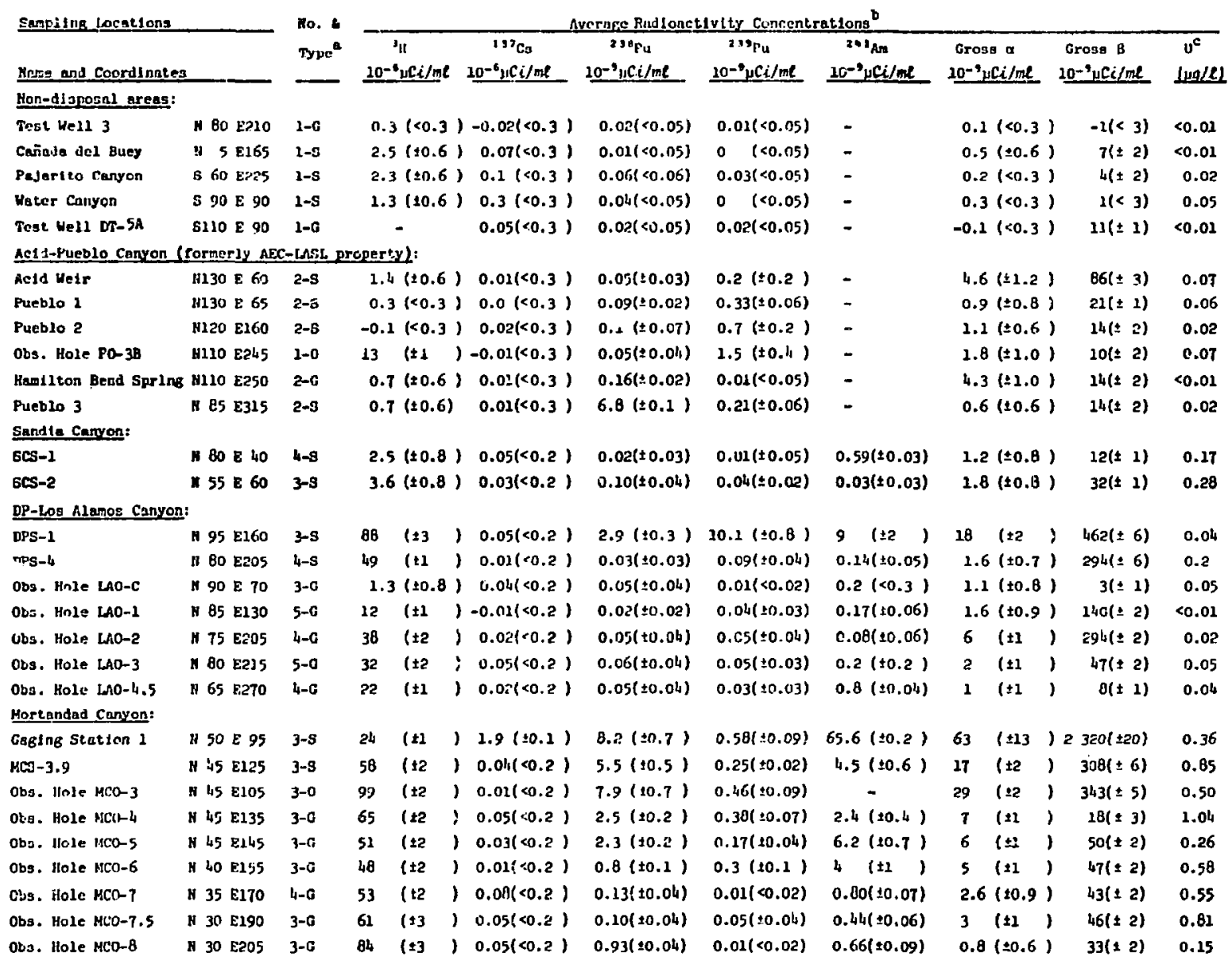

\footnotetext{
Mumber of samples collected during the year and type of source: 0 - ground vater; 8 - aur face water.

balues preceding the brackets are the actual data obtalned; values vilhin the brackets Indleate elther (土2 S.D.) or (\&OL).

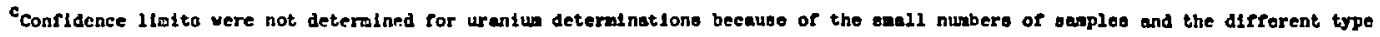
of atatiutice Involved.
}

\section{Regional Soils and Sediments}

Soil and sediment samples, collected in the same general locations as the 1 agional water samples shown in Fig. 8 , were analyzed to provide data on the normal concentrations of radioactive materials in the environment beyond the range of possible influence by LASL operations (Table XIII).

\section{E. Los Alamos Soils and Sediments}

Soil and sediment samples were collected in the general vicinity of the Laboratory and Los Alamos County, as shown in Fig. 10, and data from these samples are listed in Table XIV. The radioactivity concentrations measured in soil at off-site locations were within the expected range for contamination from global fallout. Two on-site soil 
TABLE XI

\section{RADIOACTIVITY IN EFFLUENTS FROM INDUSTRIAL WASTE TREATMENT FACILITIES}

Facllity (Location):

Total Volue Dlacharged (Recelving Canyon):

\begin{tabular}{|c|c|c|}
\hline Type of Actirity & & $\mathrm{MDz}^{\mathrm{B}}$ \\
\hline${ }^{2} \mathrm{y}$ & $\overline{0.5 x}$ & $10^{-6}$ uCime \\
\hline${ }^{49} \mathrm{Sr}$ & 5 & $10^{-1} \mathrm{nC} i / \mathrm{ml}$ \\
\hline${ }^{90} 5 r$ & 2 & $10^{-9}$ uCi/ml \\
\hline " $\mathrm{Cs}$ & 50 & $10^{-9} \mu \mathrm{Ci} / \mathrm{m} \ell$ \\
\hline $230 \mathrm{Pu}$ & 0.5 & $10^{-9} \mu \mathrm{Ci} / \mathrm{ml}$ \\
\hline $299 \mathrm{Pu}$ & 0.5 & $10^{-9} \mu \mathrm{Ci} / \mathrm{ml}$ \\
\hline $201 / A$ & 0.5 & $10^{-9} \mu \mathrm{Ci} / \mathrm{ml}$ \\
\hline U, total & 0.01 & $\mu g / \ell$ \\
\hline Gross a & 20 & $10^{-9} \mathrm{\mu Ci} / \mathrm{mL}$ \\
\hline Gruss' & 3 & $10^{-9} \mu \mathrm{Ci} / \mathrm{ml}$ \\
\hline
\end{tabular}

TA-50-1 (N 30 \& 9.3 )

\begin{tabular}{|c|c|}
\hline $\begin{array}{l}\text { Total Annual } \\
\text { Relcage }\end{array}$ & $\begin{array}{l}\text { Avg. Asnuel } \\
\text { Conerntrntion }\end{array}$ \\
\hline $27.5 \mathrm{Ci}$ & $325 \times 10^{-6} \mu \mathrm{Ci} / \mathrm{ml}$ \\
\hline $4.6 \mathrm{~m}:$ & $8510^{-9} \mu \mathrm{Ci} / \mathrm{m} \ell$ \\
\hline $7.1 \mathrm{mci}$ & $13010^{-9} \mu \mathrm{Ci} / \mathrm{ml}$ \\
\hline $292.7 \pi \times C_{i}$ & $510^{-6} \mu \mathrm{Ci} / \mathrm{mc}$ \\
\hline $8.4 \mathrm{mct}$ & $2150 \quad 10^{-9} \mu \mathrm{Ci} / \mathrm{mt}$ \\
\hline $0.6 \mathrm{mci}$ & $1110^{-9} \mu \mathrm{Ci} / \mathrm{mL}$ \\
\hline $1.4 \mathrm{mce}$ & $2510^{-9} \mathrm{\mu Ci} / \mathrm{ml}$ \\
\hline $1.4 \mathrm{~kg}$ & $26 \mu g / \ell$ \\
\hline $14.6 \mathrm{mci}$ & $27010^{-9} \mu \mathrm{Ci} / \mathrm{ml}$ \\
\hline 970 raci & $18 \mathrm{NO}^{-6}{ }_{\mathrm{CC}} \mathrm{Ciml}$ \\
\hline
\end{tabular}

TA-21-25T (N B2 E169)

\begin{tabular}{|c|c|c|}
\hline $\begin{array}{l}\text { Total Annusl } \\
\text { Melense }\end{array}$ & \multicolumn{2}{|c|}{$\begin{array}{l}\text { Avg. Annual } \\
\text { Concentration }\end{array}$} \\
\hline $1.5 \mathrm{Ci}$ & \multicolumn{2}{|c|}{$260 \times 10^{-6} \mu \mathrm{Ci} / \mathrm{m}$} \\
\hline $0.3 \mathrm{mCl}$ & 45 & $10^{-1} \mu \mathrm{Ci} / \mathrm{ml}$ \\
\hline $0.4 \mathrm{mCl}$ & 70 & $10^{-1} \mu \mathrm{Ci} / \mathrm{ml}$ \\
\hline $1.1 \mathrm{mCi}$ & 202 & $10^{-9}{ }_{\mu} \mathrm{Cl} / \mathrm{ml}$ \\
\hline $0.2 \mathrm{mCi}$ & 40 & $10^{-3} \mu \mathrm{Ci} / \mathrm{ml}$ \\
\hline $0.2 \mathrm{mci}$ & 30 & $10^{-2} \mu \mathrm{Ci} / \mathrm{me}$ \\
\hline $0.1 \mathrm{mCi}$ & 20 & $10^{-3} \mu \mathrm{Ci} / \mathrm{m} \ell$ \\
\hline $0.1 \mathrm{~kg}$ & 23 & $\mu g / \ell$ \\
\hline $0.9 \mathrm{mCi}$ & 150 & $10^{-9} \mu \mathrm{Ci} / \mathrm{ml}$ \\
\hline $29 \mathrm{mCl}$ & 5 & $10^{-1} \mu \mathrm{Ci} / \mathrm{ml}$ \\
\hline
\end{tabular}

The wDI in this table aro differeut from those shown eloeuthere becauso the analyoes vere wade in a different laboratory.

TABLE XII

RADIOACTIVITY IN SANITARY SEWAGE EFFLUENTS

\begin{tabular}{|c|c|c|c|c|}
\hline \multirow{2}{*}{\multicolumn{2}{|c|}{$\begin{array}{l}\text { Areas served: } \\
\text { No, of anples: }\end{array}$}} & \multicolumn{3}{|c|}{ Ierelinicnl } \\
\hline & & \multirow{2}{*}{\multicolumn{3}{|c|}{$\frac{11 \text { Sinnules }}{\text { Radioactivity Concentrations }\left(10^{-9} \mu C(j / m L)^{b}\right.}$}} \\
\hline Type of & $\mathrm{MDL}^{\mathrm{B}}$ & & & \\
\hline \multicolumn{2}{|c|}{ Activity $\left(1 a^{-9} \mathrm{pCl} / \mathrm{m} l\right)^{\mathrm{b}}$} & Minimun & Mex1mum ${ }^{\mathrm{C}}$ & Average $^{c}$ \\
\hline${ }^{3_{H}}$ & 300 & $\begin{array}{c}0 \\
(<300)\end{array}$ & $\begin{array}{l}20600 \\
( \pm 1200)\end{array}$ & $\begin{array}{r}4700 \\
( \pm 13600)\end{array}$ \\
\hline${ }^{137} \mathrm{Ce}$ & 65 & $\begin{array}{l}-37 \\
( \pm 66)\end{array}$ & $\begin{array}{c}35 \\
( \pm 80)\end{array}$ & $\begin{array}{c}9 \\
( \pm 46)\end{array}$ \\
\hline${ }^{234} \mathrm{Pu}$ & 0.05 & $\begin{array}{c}0.01 \\
( \pm 0.04)\end{array}$ & $\begin{array}{c}0.24 \\
( \pm 0.012)\end{array}$ & $\begin{array}{c}0.08 \\
( \pm 0.08)\end{array}$ \\
\hline $239 \mathrm{pu}$ & 0.05 & $\begin{array}{r}0.002 \\
( \pm 0.03)\end{array}$ & $\begin{array}{c}0.41 \\
( \pm 0.08)\end{array}$ & $\begin{array}{c}0.09 \\
( \pm 0.26)\end{array}$ \\
\hline v. Total & 0.004 & $\begin{array}{l}<0.004 \\
( \pm 0.003)\end{array}$ & $\begin{array}{r}0.096 \\
( \pm 0.05)\end{array}$ & $\begin{array}{r}<0.019 \\
( \pm 0.05)\end{array}$ \\
\hline Grose a & 0.3 & $\begin{array}{c}0 \\
(<0.3)\end{array}$ & $\begin{array}{c}2.6 \\
\{ \pm 0.6\}\end{array}$ & $\begin{array}{c}1.6 \\
( \pm 1.6)\end{array}$ \\
\hline Gross B & 3 & $\begin{array}{c}3.8 \\
( \pm 1.0)\end{array}$ & $\begin{array}{c}15.2 \\
( \pm 1.4)\end{array}$ & $\begin{array}{c}9.0 \\
( \pm 7.6)\end{array}$ \\
\hline
\end{tabular}

\begin{tabular}{|c|c|c|}
\hline \multicolumn{3}{|c|}{ Munic1pal } \\
\hline \multicolumn{3}{|c|}{8 Samples } \\
\hline \multicolumn{3}{|c|}{ Pad foact ivity Concentratlons $\left(10^{-9} \mathrm{HCi} / \mathrm{ml}\right)^{b}$} \\
\hline Minimum ${ }^{c}$ & Moximum ${ }^{c}$ & Averaze ${ }^{c}$ \\
\hline 0 & 1600 & 800 \\
\hline$(<300)$ & $( \pm 600)$ & $( \pm 1000)$ \\
\hline-5 & 67 & 27 \\
\hline$(+35)$ & $( \pm 94)$ & $( \pm 58)$ \\
\hline 0.006 & 0.13 & 0.046 \\
\hline$( \pm 0.012)$ & $( \pm 0.04)$ & $( \pm 0.008)$ \\
\hline 0.001 & 0.15 & 0.03 \\
\hline$(10.016)$ & $( \pm 0.06)$ & $( \pm 0.10)$ \\
\hline$<0.004$ & 0.033 & 0.016 \\
\hline$( \pm 0.003)$ & $( \pm 0.016)$ & $( \pm 0.023)$ \\
\hline 0.1 & 2.6 & 0.9 \\
\hline$(<0.3\}$ & $( \pm 0.6)$ & (t2.6) \\
\hline 1.5 & 19.1 & 10.9 \\
\hline$( \pm 1.2)$ & $(t 1.6)$ & $( \pm 10.0)$ \\
\hline
\end{tabular}

MDL = Nominal minimum detection linit at the $95 \%$ confidence level.

I pCile - $10^{-9} \mathrm{HCi} / \mathrm{ml}=3 \mathrm{~T}$ (disintegrations)/s-n'.

'The actual noelyticel data are show even though pumericaliy they way be less than the MDL; values in parenthesea indicate 2 atendard deviationo of the mean value. 


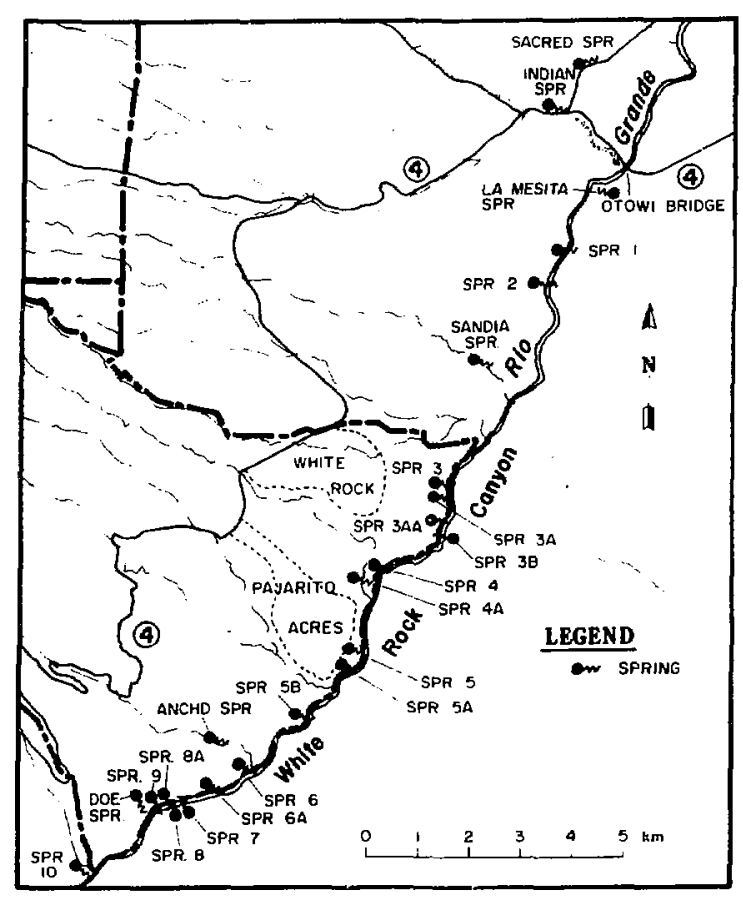

Fig. 9.

Water sampling locations in White Rock Canyon of tho Rio Grande.

samples exhibited plutonium concentrations above normal background, possibly as a result of airborne contamination in the analy tical laboratory.

Sediment samples collected near the lower ends of Pueblo (N 70 E 350) and Los Alamos Canyons (N $65 \mathrm{E} 355$ ) contained ${ }^{239} \mathrm{Pu}$ in concentrations above normal background. Pueblo Canyon received radioactive liquid effluents until 1964, and some wastes are still being released to Los Alamos Canyon. The sediments in the canyons have adsorbed radionuclides and have been transported down the canyons by storm run-off.

Sediment samples from two other on-site locations (N $35 \mathrm{E} 165$ and $\mathrm{S} 70 \mathrm{E} 160$ ) also contained plutonium in amounts above normal background concentrations. These locations are in areas that receive effluents from industrial waste treatment plants.

Radioactivity concentrations in all other soil and sedjment samples approximated those reported in previous years."
TABLE XIII

\section{RADIOACTIVITY IN REGIONAL SOIL AND SEDIMENT}

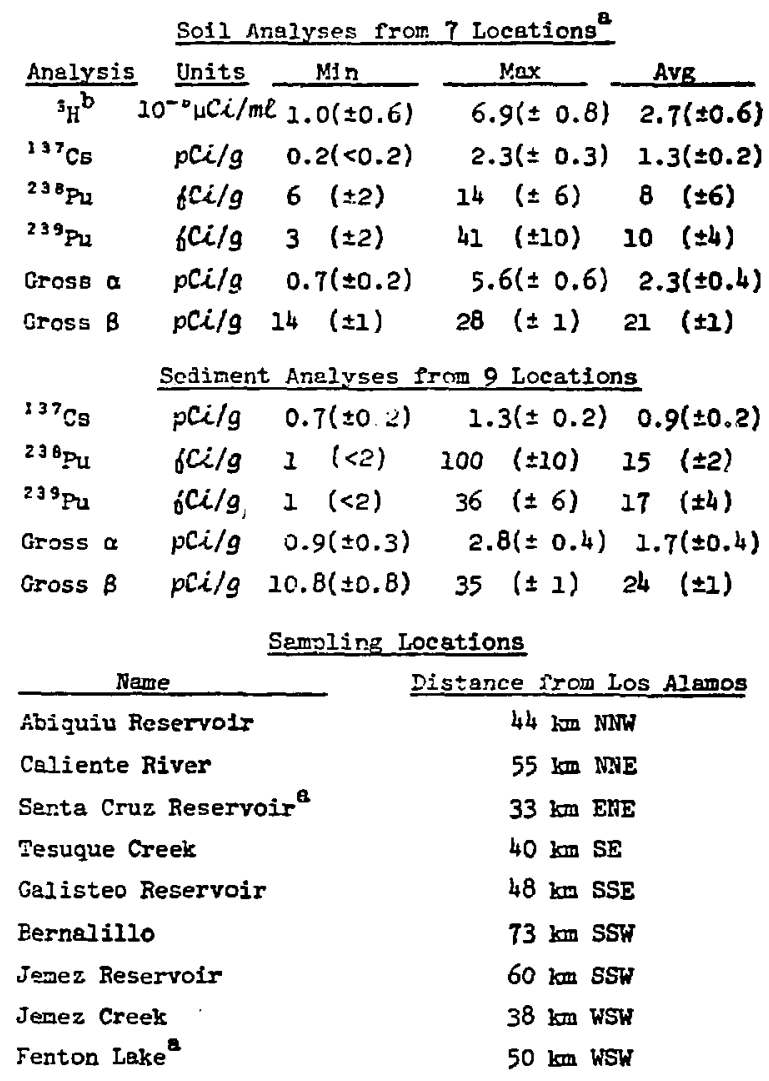

"Soil samples not collected at Santa Cruz Reservoir and Fenton Lake.

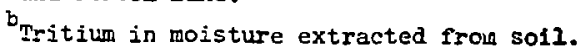

\section{ECOLOGICAL INVESTIGATIONS}

\section{A. Overview}

The Ecology Section of the Environmental Studies Group is engaged in a variety of research directed toward specific ecological problems. Much of the information obtained in the course of specialized ecological studics is also broadly applicabie to environmental monitoring. It not only supplements the direct monitoring program, but 


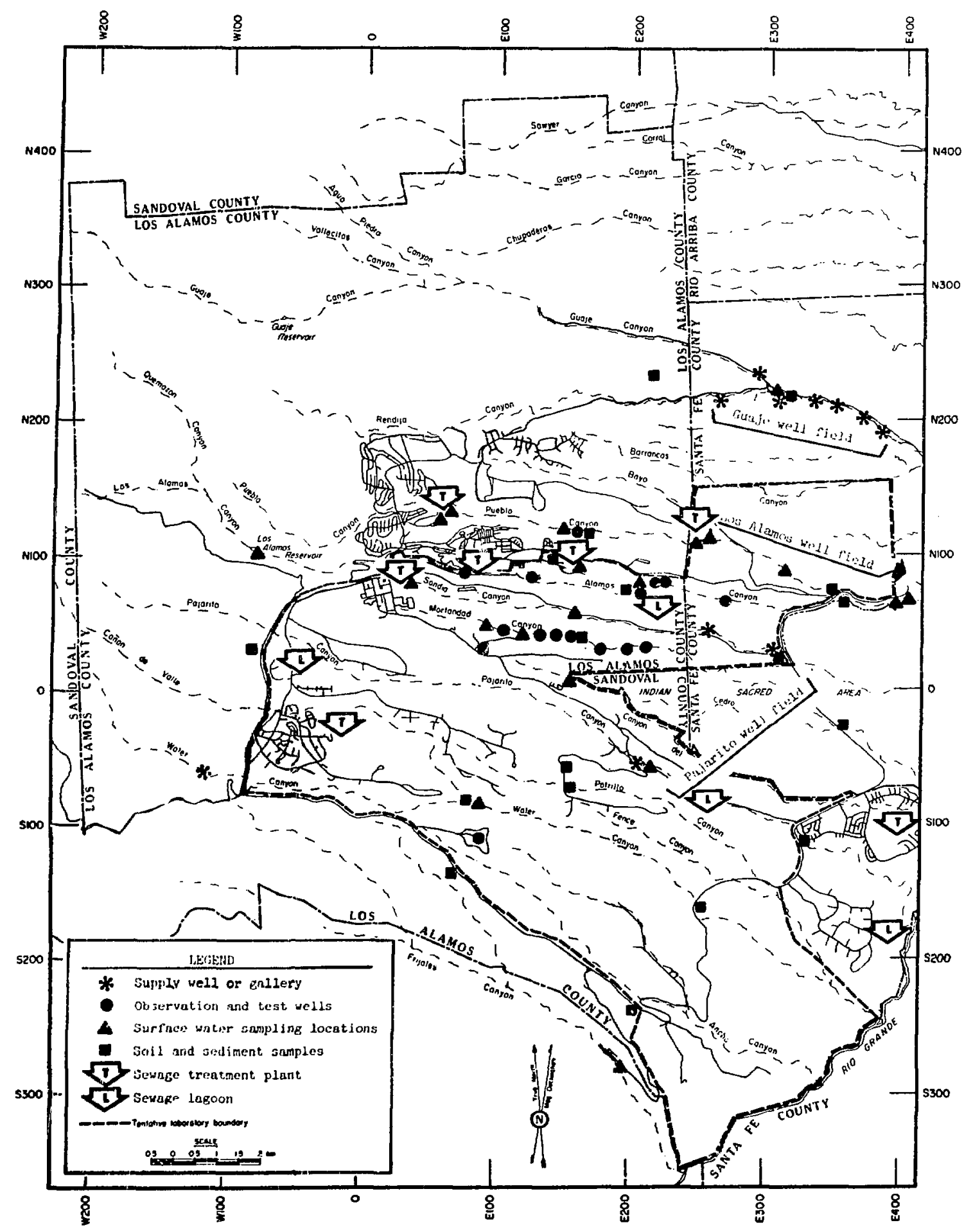

Fig. 10.

Water, sediment, and soil sampling locations on or near the LASL site. 
TABLE XIV

RADIOACTIVITY IN SOIL AND SEDIMENT IN LOS ALAMOS COUNTY

\begin{tabular}{|c|c|c|c|c|c|c|}
\hline \multirow[b]{2}{*}{ Sampling Locations } & & & & & & \\
\hline & $\begin{array}{c}{ }^{3} \mathrm{H}^{\mathrm{a}} \\
\ln \mathrm{C} i / \ell \mid \\
\end{array}$ & $\begin{array}{r}1{ }^{137} \mathrm{Cs} \\
(p C i / g) \\
\end{array}$ & $\begin{array}{r}2{ }^{{ }^{8}} \mathrm{Pu} \\
(f C c / a) \\
\end{array}$ & $\begin{array}{r}23{ }^{29 u} \\
(f C i / g) \\
\end{array}$ & $\begin{array}{l}\text { Gross } \alpha \\
\left|p C_{i} / g\right|\end{array}$ & $\begin{array}{l}\text { Gross B } \\
|p c i / g|\end{array}$ \\
\hline \multicolumn{7}{|l|}{ Orf-site soils: } \\
\hline N230 E215 & $4( \pm 1)$ & $2.8( \pm 0.3)$ & $14(<16)$ & $60( \pm 40)$ & $2.2( \pm 0.4)$ & $31( \pm 1)$ \\
\hline$N 30 \mathrm{~W} 80$ & $2( \pm 1)$ & $1.1( \pm 0.2)$ & $7(<32)$ & $6( \pm 3)$ & $8.9( \pm 0.8)$ & $40( \pm 1)$ \\
\hline S135 E205 & $2(+1)$ & $2.1( \pm 0.2)$ & $5(<20)$ & $27( \pm 4)$ & $4.6( \pm 0.6)$ & $32( \pm 2)$ \\
\hline 5240 E205 & $4( \pm 1)$ & $2 . \pm( \pm 0.3)$ & - & - & $1.4( \pm 0.4)$ & $25( \pm 1)$ \\
\hline \multicolumn{7}{|l|}{ On-site soils: } \\
\hline N $95 \quad E 145$ & $12( \pm 1)$ & $1.8( \pm 0.2)$ & $16( \pm 3)$ & $1200( \pm 80)$ & $3.0( \pm 0.4)$ & $29( \pm 1)$ \\
\hline N 30 E100 & $13( \pm 1)$ & $1.2( \pm 0.2)$ & $7( \pm 3)$ & $15( \pm 4)$ & $2.2( \pm 0.4)$ & $27( \pm 1)$ \\
\hline N 20 E310 & $5( \pm 1)$ & $2.7( \pm 0.3)$ & $120( \pm 10)$ & $58( \pm 8)$ & $2.8( \pm 0.4)$ & $32( \pm 1)$ \\
\hline$S 55 E 55$ & $6( \pm 1)$ & $2.1( \pm 0.2)$ & $8( \pm 3)$ & $57( \pm 8)$ & $2.6( \pm 0.4)$ & $29( \pm 1)$ \\
\hline \multicolumn{7}{|l|}{ Off-site sediments: } \\
\hline N210 E320 & - & $0.9( \pm 0.2)$ & - & - & $0.9( \pm 0.3)$ & $19( \pm 1)$ \\
\hline $\mathrm{N} 120 \mathrm{E} 65$ & - & $0.9( \pm 0.2)$ & $5( \pm 3)$ & $5( \pm 3)$ & $2.0( \pm 0.4)$ & $27( \pm 1)$ \\
\hline N 70 E350 & - & $1.6( \pm 0.2)$ & $25( \pm 10)$ & $560( \pm 80)$ & $2.7( \pm 0.4)$ & $29( \pm 1)$ \\
\hline N 65 E355 & - & $3.2( \pm 0.3)$ & $14( \pm 4)$ & $130( \pm 10)$ & $0.5(<0.6)$ & $33( \pm 1)$ \\
\hline S 30 E360 & - & $0.8( \pm 0.2)$ & - & - & $1.8( \pm 0.4)$ & $27( \pm 1)$ \\
\hline S105 E330 & - & $3.4( \pm 0.3)$ & $8( \pm 3)$ & $20( \pm 4)$ & $1.4( \pm 0.4)$ & $25( \pm 1)$ \\
\hline \multicolumn{7}{|l|}{ On-site sediments: } \\
\hline N 75 E205 & - & $1.7( \pm 0.2)$ & $8( \pm 4)$ & $100( \pm 20)$ & $0.9( \pm 0.4)$ & $18( \pm 1)$ \\
\hline IN 35 E165 & - & $1140 \quad( \pm 4)$ & $75( \pm 6)$ & $1300( \pm 100)$ & $2.6( \pm 0.4)$ & $89( \pm 2)$ \\
\hline S 70 E160 & - & $0.7( \pm 0.2)$ & $\mu 1( \pm 3)$ & $210( \pm 20)$ & - & - \\
\hline S 85 E 95 & - & - & - & - & $4.4( \pm 0.6)$ & $39( \pm 1)$ \\
\hline S160 E255 & - & $0.9( \pm 0.2)$ & $6( \pm 6)$ & $13( \pm 6)$ & $1.3( \pm 0.4)$ & $21( \pm 1)$ \\
\hline
\end{tabular}

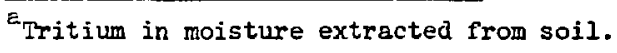

provides insight into the proper interpretation of environmental monitoring data. Duplication of effort is avoided by incorporating the results of ecological studies in to the environmental monitoring program.

The following sections summarize some current ecological studies that are especially relevant to the environmental monitoring program. Although these studies have been initiated only recently and cannot yet provide the complete evaluations desired, they are already beginning to have an impact on the environmental monitoring program and on planning for more effective environmental controls.

\section{B. Environmental Inventory}

The variety of Laboratory activities and research programs dictates the need for a thorough environmental resources inventory of the Los Alamos area. For example, hazard assessinents and radionuclide inventories arising from the Laboratory's waste disposal practices, recommendations for plutonium standards for soils, and the establishment of the Laboratory property as a National Environmental Research Park are all current efforts that require or could benefit from information on the environmental resources of the Los Alamos area. 
Specific to environmental monitoring activities, information on the flora of the area would provide input for the prediction of atmospheric effluent behavior because the types, longevity, and gross morphology of the plant species may be important factors determining the removal of radionuclides from air. In addition, the types of vegetative cover are expected to have an important bearing on the radionuclide content of soils surrounding the Laboratory. Information on the types and characteristics of the soils will be vital to assessing long-term build-up and behavior of the various radioactive effluents in the abiotic and biotie environment.

Most TAs that release radionuclides to the air are located in the middle of the Transition Life Zonc at an elevation of about 2.1-2.2 km above sea level. Ponderosa pine (Pinus ponderosa) is the major overstory plant in the mid-Transition Zone and covers about $75 \%$ of the nondisturbed landscape. This species is long-lived, and at Los Alamos the present stand is $10-30 \mathrm{~m}$ in height and is estimated to be $30-300$ years old. The wide range in heighi $i$ and age of the stand can be attributed to past logging activities. In the lower Transition Zone, which occurs to the east and downwind side of most of the TAs, the dominant tree cover is a mixture of pinon pine (Pinus edulis) and one-seeded juniper (Juniperus monosperma). Both species are evergreens and have longevity and morphological characteristics similar to ponderosa pine.

The relatively dense cover formed by the tree canopy may reduce the importance of wind transport of resuspended particles as a mechanisin in the redistribution of ground-deposited radionuclides. On the other hand, soils exposed by mechanical disturbance are readily transported by wind, hence proper planning of construction activities and final restoration of a protective vegetation covering is important.

The biotic resources inventory already includes a listing and library of plant and animal species (including several rare and endangered or game species) occurring in Los Alamos County. Quantitative work on the vegetation of the area and an inventory of local soils will be continued in 1974.

\section{The Honeybee as a Potential Indicator Organism}

Relatively high tritium concentrations (up to $9.6 \times 10^{-3} \mu \mathrm{Ci} / \mathrm{m} \ell$ ) were found in bees from four LASL areas during 1972. ${ }^{2}$ Subsequent experiments showed that caged bees do not concentrate tritium above the levels in a supplied food; consequently, the high concentrations observed in unconfined bees $(200-400$ times the concentrations found in liquid effluents) could not have been attained solely by ingestion of effluents.
Nectar from flowering vegetation is probably the major tritium source to all honcybee colonies because the tritium concentrations in flower moisture were equal to or exceeded the levels in bees. Tritium sources in vegetation include atmospheric effluents and buried solid waste.

Tritium concentrations in bees cannot be compared with those from stack effluents because data are lacking on the chemical form of the tritium in the effluents. However, preliminary studies indicate that most of the tritium released at TA-33 (the major source of airborne tritium in the vicinity of the honeybee study areas) is in the oxide form.

Routine measurements of tritium in atmospheric moisture at locations near the honeybee study areas did not correlate well with concentrations in the bees. In Mortandad Canyon and S-Site the correlation coefficients $r$ were $0.50(n=16)$ and $0.42(n=17)$, respectively, which were significant at $\alpha<0.05$; in Acid-Pueblo and DP Canyons, the correlation coefficients were not significant $(\alpha<0.05)$. Regression analyses for all four locations indicated that the tritium in honeybees averaged 2-200 rimes that in air moisture samples. There were significant correlations $(\alpha=0.05)$ between tritium concentrations in bees and in vegetation from Mortandad and DP Canyons but not for Acid-Puebio Canyon and S-Site.

It is difficult to assess the utility of honeybees as bio-indicators of tritium entering the environment from a specific source. The bees used three sources of tritium during at least part of the 17 -month study period. During the spring of 1973, bee colonies in Mortandad and DP Canyons used the effluent water and ingested ${ }^{137} \mathrm{Cs},{ }^{238} \mathrm{Pu}$, and ${ }^{239} \mathrm{Pu}$, as well as tritium. During the summer, large areas of vegetation contaminated by airborne tritium were a potential source to bees. In the fall, a late blooming stand of white clover (Melilotus albus) growing over an old solid waste burial ground was the probable source of unexpectedly high tritium levels in the Mortandad Capnyon bee colony.

At present, we can draw two conclusions relating to the honeybee studies. First, honeybees in the LASL environment can accumulate tritium from the environment and, in the process, can encounter concentrations that may not be measured during corresponding time periods by the Laboratory's air monitoring network. Second, honeybees are useful in identifying sources of tritium to biota. Vegetation over relatively large areas is a potential source of tritium to nectivorous as well as herbivorous animals. In addition, moisture in vegetation growing over an old solid waste burial site has been identified as a potential source of fairly intense tritium concentrations $(\approx 1 \mu \mathrm{Ci} / \mathrm{ml})$. 


\section{Radionuclides in Canyon Ecosystems}

A detailed study of radionuclide behavior in threc canyon areas was begun in 1972 :

(1) Aciu-Pueblo Canyon received untreated liquid radioactive wastes from 1943 to 1951 , and received effluent from the TA-45 treatment plant from 1951 to 1964. The facility was subsequently decommissioned and dismantled, and Acid-Pueblo Canyon has received no liquid wastes for about 10 years.

(2) Di'-Los Alamos Canyon has been receiving the effluent from the creatment plant at TA-21 since 1952 . However, this facility will probably be decommissioned with in the next few years.

(3) Mortandad Canyon has received the effluent from the TA $A_{\mathrm{b}}-50$ treatment plant since 1963 . This plant is scheduled to handle larger quantities of plutoniumcontaminated wastes when a new plutonium research facility is completed.

These three canyon areas provide a unique opportunity for investigating the behavior of plutonium in environments that are in three different stages of temporal impact: (1) an area that has not received plutonium waste for a clecade, (2) an area that has received plutonium wastc for two decades and that soon will not receive any more, and (3) an area that has received plutonium waste for a decade and that will continue to receive it.

The relationship of the canyon radicecology studies to the routine environmental surveiliance program can be appreciated more fully when one realizes that these canyons also represent three different situations as far as control of released radioactivity is concerned. During its time of active use, that part of Acid-Pueblo Canyon from the waste treatment plant to $\approx 9 \mathrm{~km}$ below the plant outfall was owned by the AEC. The upper $5 \mathrm{~km}$ of this drainage area has subsequently been transferred to public and private ownership and is no longer part of the LASL site. Thus, radioactivity that was once on site is now off site as a result of administrative actions rather than environmental transport.

The DP-Los Alamos Canyon is located entirely on the LASL site until its confluence with Acid-Pueblo Canyon, about $6 \mathrm{~km}$ below the outfall from the TA-21 plant. Mortandad Canyon is within the LASL boundary for a distance of $5 \mathrm{~km}$ below the TA-50 outfall, at which point it becomes Indian land.

A geometric progression of sampling stations was selected and permanently marked in each of the three canyons. These stations are located at the waste outfalls, and at $20,40,80,160,320,640,1280,2560,5120$, and $10240 \mathrm{~m}$ below the release points. Two stations at 100 and $200 \mathrm{~m}$ above the outfalls were selected as background reference locations in each canyon. At each station, measurements have been made of the external radiation exposure rates and of the concentrations of cricium, ${ }^{137} \mathrm{Cs}$, and total plutonium in environmental media. Data on tritium and ${ }^{137} \mathrm{Cs}$ concentrations in sediments, vegetation, and various fauna, as well as further details on the design of these studies, have been reported elsewhere. ${ }^{2}$ A sunmary of the external exposurc rate measurements and of the pluconium concentrations found in environmental samples is presented here as an adjunct to other environmental monitoring data.

(1) Extcrnal exposure rates were measured with a scintillation survey meter and a pressurized ionization chamber. Because of the energy dependence of the $\mathrm{NaI(Tl)}$ crystal, the scintillation survey meter overresponded to the lowenergy gamma rays in the environment by about a factor of 2, compared with the response to the gamma ravs from ${ }^{60} \mathrm{Co}$ used in its calibration. The scintillation survey meter, because of its sensitivity and rapid response, was particularly useful for assessing the variability of exposure rates. The ionization chamber provided the most accurate measurements because of its uniform response over a wide range of gamma-ray energies (0.1-10 MeV).

External exposure rates are given in Table XV. The highest exposure rates were observed a few hundred meters below the effluent outfall in each canyon, corresponding to areas of highest ${ }^{137} \mathrm{Cs}$ concentrations. The scintillation survey meter measurements correlated well with the data for ${ }^{137} \mathrm{Cs}$ in the top $75 \mathrm{~mm}$ of sediment in DP-Los Alamos and Mortandad Canyons, but not in Acid-Pueblo Canyon. Correlation coefficients of 0.81 and $0.80(n=11)$ for DP-Los Alamos and Mortandad Canyons, respectively, were significant at $\alpha=0.01$.

(2) Radionuclides in alluvial soils. Maximum concentrations of plutonium in alluvial sediments occurred within $320 \mathrm{~m}$ of the respective effluent outfalls (Table XVI). Over $300 \mathrm{pCi}{ }^{239} \mathrm{Pu} / \mathrm{g}$ (dry) was measured in Mortandad Canyon sediments, whereas $82.2 \mathrm{pCi}^{239} \mathrm{Pu} / \mathrm{g}$ and $54 \mathrm{pCi}$ ${ }^{239} \mathrm{Pu} / \mathrm{g}$ were the maxima for Acid-Pueblo and DP-Los Alamos Canyons. Concentratioris generally decreased with increasing distance beyond the outfall.

There was considerable heterogeneity of plutonium concentrations in replicate sediment samples. The coefficients of variacion ( $\mathrm{CV}=100 \mathrm{x}$ std dev/mean) among triplicate samples were typically about $80 \%$. Inter-sample variability yielded CVs of $10-15 \%$ compared to CVs of less than 7\% from analytical me thods.

A distributional relationship apparently exists between the ${ }^{137} \mathrm{Cs}$ and plutonium concentrations in post-outfall stream channel sediments. Linear regressions on the sediment concentrations of ${ }^{137} \mathrm{Cs}$ vs ${ }^{238} \mathrm{Pu}$ and ${ }^{137} \mathrm{Cs}$ vs ${ }^{239} \mathrm{Pu}$ in 
TABLE XV

EXTERNAL RADIATION EXPOSURE RATES IN LIQUID WASTE RECEIVING CANYONS

External Exposure Rates $(\mu R / h)$

\begin{tabular}{|c|c|c|c|c|c|c|c|c|c|}
\hline \multirow{4}{*}{$\begin{array}{l}\text { Distance from } \\
\text { Waste Outfall }\end{array}$} & \\
\hline & \multicolumn{3}{|c|}{ Acia-Dueblo Canvon } & \multicolumn{3}{|c|}{ DP-Los Alamos Canyon } & \multicolumn{3}{|c|}{ Mortandad Canron } \\
\hline & \multicolumn{2}{|c|}{ Scint. ${ }^{a}$} & \multirow{2}{*}{$\begin{array}{l}\text { Ion } \mathrm{Ch} .^{\mathrm{b}} \\
\mathrm{h}=0.5 \mathrm{~m}\end{array}$} & \multicolumn{2}{|c|}{ Scint. ${ }^{\mathrm{a}}$} & \multirow{2}{*}{$\frac{\text { Ion } \mathrm{Ch} .^{\mathrm{b}}}{\mathrm{h}=0.5 \mathrm{~m}}$} & \multicolumn{2}{|c|}{ Scint. ${ }^{a}$} & \multirow{2}{*}{$\begin{array}{l}\text { Ion } \mathrm{Ch}^{\mathrm{b}} \\
\mathrm{h}=0.5 \mathrm{~m}\end{array}$} \\
\hline & $\underline{n}=0$ & $\underline{h}=1 \mathrm{~m}$ & & $\underline{h}=0$ & $\underline{h}=1 \mathrm{~m}$ & & $h=0$ & $\mathrm{~h}=1 \mathrm{~m}$ & \\
\hline$-200 m^{2}$ & 22 & 28 & 8 & 30 & 42 & 16 & 26 & 28 & 16 \\
\hline 0 & 30 & 40 & 21 & 750 & 600 & $>150$ & 750 & 425 & $>150$ \\
\hline $20 \mathrm{~m}$ & 40 & 50 & 25 & 800 & 800 & $>150$ & 700 & 400 & $>150$ \\
\hline $40 \mathrm{~m}$ & 40 & 35 & 21 & 300 & 160 & 87 & 1500 & 700 & $>150$ \\
\hline $80 \mathrm{~m}$ & 85 & 50 & 29 & 220 & 160 & 76 & 1100 & 550 & $>150$ \\
\hline $160 \mathrm{~m}$ & 40 & 50 & 23 & 50 & 45 & 26 & 1400 & 700 & $>150$ \\
\hline $320 \mathrm{~m}$ & 40 & 50 & 18 & 140 & 160 & 54 & 1300 & 800 & $>150$ \\
\hline $640 \mathrm{~m}$ & - & - & - & 110 & 110 & - & 600 & 450 & $>150$ \\
\hline $1.28 \mathrm{~km}$ & 50 & 60 & 21 & - & - & - & 300 & 250 & 91 \\
\hline $2.56 \mathrm{~km}$ & 30 & 35 & 18 & 110 & 80 & - & 160 & 150 & 71 \\
\hline m & 26 & 20 & 15 & 35 & 40 & 21 & 30 & 30 & 17 \\
\hline $10.24 \mathrm{~km}$ & - & - & - & - & - & - & 26 & 28 & 16 \\
\hline
\end{tabular}

\footnotetext{
a Fortable scintillation survey meter (Luảlum Model $12 \mathrm{~S}$ ) with NaI (TI) crystal.

bressurized ionization chamber (Reuter-Stokes Model RSS-1ll); maximum range $=150 \mu R / h$.

Background location upstream from outfalls.
}

TABLE XVI

\section{PLUTONIUM IN SEDIMENTS IN LIQUID WASTE RECEIVING CANYONS}

\begin{tabular}{|c|c|c|c|c|c|c|c|c|c|c|c|c|c|c|}
\hline \multirow{4}{*}{$\begin{array}{l}\text { Distance from } \\
\text { Heste Outfall } \\
-200 \mathrm{~m}^{\mathrm{a}}\end{array}$} & \multicolumn{14}{|c|}{ Flutonium Concentrations (oci/a dry) } \\
\hline & \multicolumn{4}{|c|}{ Ac1d-Pueblo Canyon } & \multicolumn{5}{|c|}{ DP-Las Alamos Canyon } & \multicolumn{5}{|c|}{ Mortandad Canyon } \\
\hline & \multirow{2}{*}{$\frac{\operatorname{Min}}{0.4}$} & \multirow{2}{*}{$\frac{\operatorname{Max}}{9}$} & \multicolumn{2}{|c|}{ Avg } & \multirow{2}{*}{$\frac{\min }{0.01}$} & \multirow{2}{*}{$\frac{\operatorname{Max}}{0.07}$} & \multicolumn{3}{|c|}{ Ave } & \multirow{2}{*}{$\frac{\operatorname{Min}}{0.4}$} & \multirow{2}{*}{$\frac{\operatorname{Max}}{16}$} & \multicolumn{3}{|c|}{ Avg } \\
\hline & & & $31 \pm$ & $j^{b}$ & & & 0.01 & $4( \pm 0.0$ & $02)^{b}$ & & & 5 & $\Leftrightarrow \quad 8$ & )$^{2}$ \\
\hline$-100 \mathrm{~m}^{2}$ & 0.1 & 0.1 & $0.11 \pm$ & $0.02)$ & 0.01 & 0.1 & 0.05 & $5( \pm 0.0$ & & 0.3 & 0.8 & 0.5 & $( \pm 0$. & $0.1)$ \\
\hline 0 & 0.7 & 5.7 & $2.5( \pm$ & $2.8)$ & 22 & 54 & 38 & $( \pm 23$ & 1 & 140 & 290 & 220 & $( \pm 70$ & J \\
\hline $20 \mathrm{mg}$ & 1 & 3 & $2( \pm$ & 1 & 4 & 47 & 9.4 & $( \pm 24$ & 1 & 3 & 310 & 180 & $( \pm 160$ & 1 \\
\hline $40 \mathrm{~m}$ & 0.4 & 14 & $6.91 \pm$ & 6.81 & 0.2 & 2 & 0.6 & $( \pm 0.8$ & ) 1 & 18 & 190 & 91 & $( \pm 90$ & ) \\
\hline $80 \mathrm{n}$ & 0.4 & $8 i^{\prime}$ & $50 \ell \pm$ & 43 & 0.3 & 6 & 3 & $1 \pm 3$ & ) & 19 & 77 & 48 & $1 \pm 28$ & ) \\
\hline $160 \mathrm{~m}$ & 10 & 15 & $13 に$ & 3.51 & 0.4 & 1 & 0.8 & $\ell=0.3$ & 3) & 22 & 250 & 120 & $1 \pm 120$ & ) \\
\hline $320 \mathrm{~m}$ & 9 & 13 & $12 〔 \pm$ & $2.7)$ & 0.3 & 54 & 19 & $( \pm 31$ & ) & 5 & 47 & 24 & $( \pm 21$ & ) \\
\hline $640 \mathrm{~m}$ & 7 & 13 & $10 \Leftrightarrow$ & 3 & 0.5 & 1 & 1 & $( \pm 0.5$ & 51 & 19 & 24 & 21 & $1 \pm 2$ & ) \\
\hline $1.28 \mathrm{~km}$ & 2 & 3 & $21 \pm$ & 1 & - & - & - & - & & 5 & 13 & 9 & $\ll \pm 4$ & 1 \\
\hline $2.56 \mathrm{~km}$ & 0.03 & 0.6 & $0.41 \pm$ & 0.31 & 0.04 & 0.3 & 0.2 & $( \pm 0.1$ & & 3 & 26 & 11 & $( \pm 13$ & ) \\
\hline $5.12 \mathrm{~km}$ & 0.6 & 2 & $1 \quad( \pm$ & $0.7)$ & 0.1 & 0.8 & 0.4 & $( \pm 0.3$ & & 0.1 & 0.2 & 0.1 & $( \pm 0$. & 1.11 \\
\hline $10.24 \mathrm{~km}$ & 0.1 & 0.3 & $0.21 \pm$ & $0.02)$ & - & - & - & - & & 0.01 & 0.1 & & $3( \pm 0$. & $.02)$ \\
\hline
\end{tabular}

\footnotetext{
Negative distrinces represent background locations upstream from the outfalls.

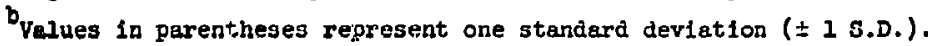


Mortandad Canyon yielded a correlation coefficient $\mathrm{r}$ of 0.64 and 0.45 , respectively, for 33 samples. The ${ }^{137} \mathrm{Cs}$ vs ${ }^{238} \mathrm{Pu}$ and ${ }^{137} \mathrm{Cs}$ vs ${ }^{239} \mathrm{Pu}$ regressions for DP-Los Alamos Canyon yielded an $r$ of 0.57 and $0.62(n=25)$. The Acid-Pueblo regressions resulted in a calculated $r$ of 0.43 $\left({ }^{137} \mathrm{Cs}\right.$ vs ${ }^{238} \mathrm{Pu}$ ) for 26 samples. A correlation coefficient of 0.65 and $0.21(n=83)$ was obtained when the postoutfall ${ }^{137} \mathrm{Cs}$ vs ${ }^{238} \mathrm{Pu}$ and ${ }^{137} \mathrm{Cs}$ vs ${ }^{239} \mathrm{Pu}$ concentrations from all the canyons were compared.

Most correlation coefficients were significant at the $5 \%$ level; however, the largest variation $\mathrm{r}^{2}$ accounted for by regression analysis was about $42 \%$, indicating that there were other sources of variability.

A positive relationship between ${ }^{137} \mathrm{Cs}$ and plutonium may provide information on the mechanisms of radionuclide distribution in each of the canyons.

(3) Radionuclides in vegetation. Plutonium concentrations in vegetation from the three canyons (Table XVII) were 100-1 000 times greater than those observed in Northern New Mexico vegetation, ${ }^{3}$ and about 0.001-1 times the concentrations per gram of sediment upon which the plants were growing.

Plutonium concentrations in vegetation varjed considerably among growth forms, such as grasses, forbs, and trees, from the same collection location. Coefficients of variation were consistently near 1.0. Algae, crustose lichens, and mosses--none of which is included in Table XVII--had the highest plutonium concentrations of any plant species, with maxima of $3,0.15$, and $0.03 \mu \mathrm{Ci} / \mathrm{g}$ (dry), respectively.

(4) Radionuclides in animal tissues. Plutonium concentrations in rodent tissues (Table XVIII) varied considerably within the same species from the same collection location. In general, the lungs and pelt contained the highest concentrations.

The ${ }^{238} \mathrm{Pu} /{ }^{239} \mathrm{Pu}$ activity ratios in the plant and animal sample types were generally indicative of plutonium concentrations in the canyons from which the samples were obtained. Mortandad Canyon sediments, vegetation, and rodent samples contained activity ratios of $3.6 \pm 1.8$, $3.9 \pm 3.5$, and $4.6 \pm 4.3$, respectively. Respective ratios for Acid-Pueblo Canyon samples averaged $0.06 \pm 1.6$, $0.32 \pm 0.55,2.0 \pm 3.0$; and for DP Canyon, $0.19 \pm 0.12$, $0.77 \pm 1.5,0.58 \pm 1.2$.

The waste disposal histories of the three canyons are quite different. Acid-Pueblo Canyon, during a 20-year period from 1943-1964, received ${ }^{239} \mathrm{Pu}$-contaminated effluent exclusively, while DP-Los Alamos Canyon, during a 20-year period (1952-present), received a combination of ${ }^{238} \mathrm{Pu}-{ }^{239} \mathrm{Pu}$-contaminated effluents which currently

\section{TABLE XVII}

\section{PLUTONIUM IN VEGETATION ${ }^{\text {a }}$ IN LIQUID WASTE RECEIVING CANYONS}

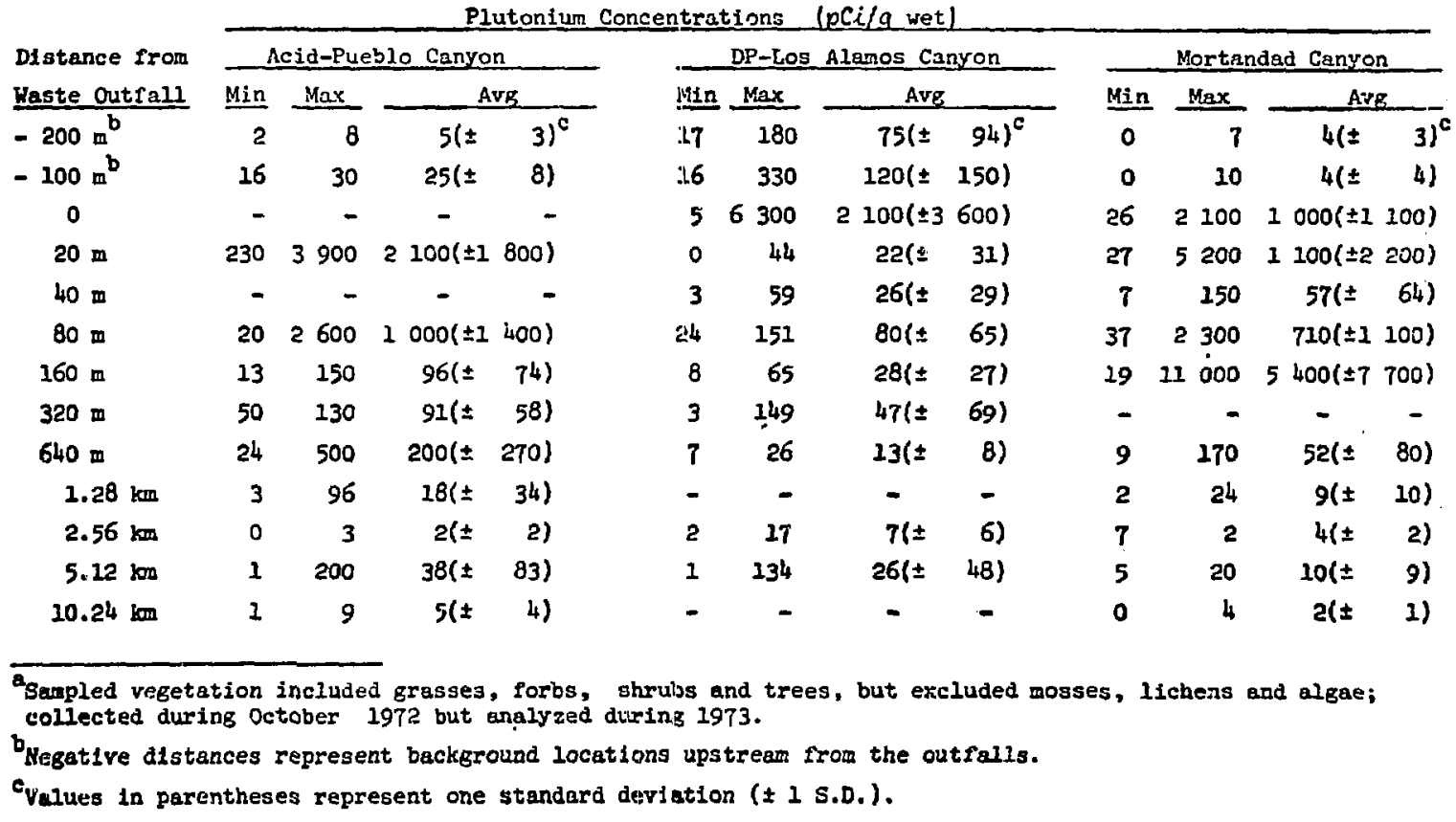


TABLE XVIII

\section{PLUTONIUM IN RODENTS IN LIQUID WASTE RECEIVING CANYONS}

\begin{tabular}{|c|c|c|c|c|c|c|c|c|c|c|c|c|c|c|}
\hline \multirow{3}{*}{$\begin{array}{l}\text { Cenyon and } \\
\text { Distance from } \\
\text { Waste Outfa? }\end{array}$} & \multicolumn{14}{|c|}{ Total Plutonium Concentration in Soft TIssues (sci/g wet) } \\
\hline & \multicolumn{3}{|c|}{ Liver } & \multicolumn{4}{|c|}{ Lungs } & \multicolumn{4}{|c|}{ Hide } & \multicolumn{3}{|c|}{ Carcass } \\
\hline & \multirow[t]{2}{*}{ Min } & \multirow[t]{2}{*}{ Max } & \multirow[t]{2}{*}{ Avg } & \multirow[t]{2}{*}{ Min } & \multirow[t]{2}{*}{$\operatorname{Mnx}$} & \multirow{2}{*}{\multicolumn{2}{|c|}{ Avg }} & \multirow{2}{*}{\multicolumn{2}{|c|}{ Min Max }} & \multicolumn{2}{|c|}{ Avg } & \multirow[t]{2}{*}{ Min } & \multirow[t]{2}{*}{$\underline{\text { Mex }}$} & \multirow{2}{*}{ AVE } \\
\hline & & & & & & & & & & & & & & \\
\hline$-0.2 \mathrm{~km}^{\mathrm{a}}$ & 2 & 10 & $7( \pm b)^{b}$ & 0 & 35 & $12 ! \pm$ & $20)^{b}$ & 2 & 7 & $5 l \pm$ & 2) $)^{b}$ & 0 & 11 & $4( \pm 5)^{b}$ \\
\hline 0 & 4 & 91 & $27( \pm 43)$ & 0 & 41 & $254 \pm$ & 18) & 67 & 226 & $144( \pm$ & 80) & 0.4 & 55 & $20( \pm 24)$ \\
\hline $2.6 \mathrm{~km}$ & 0 & 200 & $24( \pm 47)$ & 0 & 619 & $671 \pm$ & 150) & 11 & 215 & $32< \pm$ & 50) & 0 & 14 & $4( \pm 4)$ \\
\hline $10.2 \mathrm{~km}$ & 1 & 16 & $4( \pm 5)$ & 3 & 38 & $25( \pm$ & 18) & 4 & 82 & $32( \pm$ & 29) & 0.4 & 3 & $1( \pm 1)$ \\
\hline \multicolumn{15}{|l|}{ DP-Los Alemos } \\
\hline$-0.2 \mathrm{~km}^{\mathrm{a}}$ & 0 & 17 & $7( \pm 6)$ & 0 & 97 & $221 \pm$ & 34) & 95 & 970 & $4801 \pm$ & $340)$ & 0.2 & 34 & $13( \pm 13)$ \\
\hline 0 & 2 & 110 & $27( \pm 32)$ & 0 & 110 & $24( \pm$ & 27) & 72 & 680 & $310( \pm$ & 200) & 0 & 310 & $51\{ \pm 75)$ \\
\hline $2.6 \mathrm{~km}$ & 0 & 20 & $9( \pm 10)$ & 0 & 86 & $300( \pm$ & 38) & 2 & 44 & $19( \pm$ & 16) & 0 & 15 & $6( \pm 7)$ \\
\hline \multicolumn{15}{|l|}{ Kortancad } \\
\hline$-0.2 \mathrm{~km}^{\mathrm{a}}$ & - & 3 & $3-$ & 8 & 13 & $121 \pm$ & 4) & 4 & 15 & $101 \pm$ & 8) & 0 & 1 & $1( \pm 1)$ \\
\hline 0 & 9 & 66 & $33( \pm 24)$ & 19 & 1500 & $4601 \pm$ & $710)$ & 661 & 500 & $7901 \pm$ & $520)$ & 0.2 & 100 & $39( \pm 44)$ \\
\hline $2.6 \mathrm{~km}$ & 0 & 26 & $10( \pm 9)$ & 18 & 6000 & $840( \pm 2$ & 100) & 4 & 710 & $1001 \pm$ & $240 ;$ & 0 & 15 & $3( \pm 5)$ \\
\hline $10.2 \mathrm{~km}$ & 0 & 210 & $33( \pm 68)$ & 0 & 7800 & $100( \pm 2$ & $500)$ & 46 & 300 & $500( \pm 1$ & $700)$ & 0.1 & 92 & $10( \pm 25)$ \\
\hline
\end{tabular}

Megative distances represent background locations upstream from the outfalls.

balues in parentheses represent one standard deviation ( \pm I S.D.).

averages about $80 \%{ }^{239} \mathrm{Pu}$ of total activity. Mortandad Canyon, during a 10-year period (1963-present), received a mixture of ${ }^{238} \mathrm{Pu}^{239} \mathrm{Pu}$ which for the last 5 years has been at least $80 \%{ }^{238} \mathrm{Pu}$.

Severai studies should provide information useful to LASL's environmental monitoring activities. For example, studies on the rates and mechanisms of plutonium movement down canyons during high precipitation run-off periods are essential in assessing potential as well as actual off-site losses of the radionuclide. There is evidence that an important mechanism in plutonium movement is the flushing of sediments down the canyon.

Refined studies on the distribution of plutonium in the canyons' biota should provide input for the assessment of plutonium release standards for liquid effluents at LASL. Similar studies will be initiated in areas where the principal source of environmental plutonium is the effiuent released to the atmosphere. Questions regarding long-term biildup and availability of chronic, low-levcl relcases of plutonium to the environment require consideration.

\section{E. Characterization of Soils}

Much of the alluvial soil in the waste discharge areas is in deep canyons which have formed in the Bandelier tuff since Pleistocene times. The original ash-flow tuff deposits, consisting of rhyolite ash and pumice with small amounts of quartz and sanidine crystals, have weathered to form the alluvial soils in the study areas. Ten core samples were taken of the alluvium at each of 11 stations in Mortandad, DP-Los Alamos, and Acid-Pueblo Canyons during 1973. The core samples were frozen, cut into four segments (0-25, 25-75, 75-125, and 125-300 mm), oven dried, and characterized as to their physical and chemical properties.

More than $\mathbf{5 0 0}$ of these soil samples were mechanically separated in to 6 size fractions:

\section{Size Description}

Particle Diameter

Silt and clay

Very fine sand

Medium and fine sand

Coarse sand

Very coarse sand

Coarse fragments
$<53 \mu \mathrm{m}$

53-105 $\mu \mathrm{m}$

105-500 $\mu \mathrm{m}$

500-1000 $\mu \mathrm{m}$

$1.2 \mathrm{~mm}$

$2.23 \mathrm{~mm}$ 
Soil profiles of severely and moderately eroded soil from all canyons showed $<1-2 \%$ silt and clay in the top $25 \mathrm{~mm}$ of soil and $<3-4 \%$ silt and clay in the remainder. Severely eroded soils contained up to $70 \%$ coarse fragments, whereas the dominant size fraction (up to $46 \%$ by weight) in most moderately eroded soils was very coarse sand. Only 4 of the 33 stations had soils with minimal water erosion; these soils contained up to $54 \%$ silt and clay, with increasingly smaller amounts of larger size fractions. They usually contained $<10 \%$ coarse fragments (2-23-mm-diam).

The cation exchange capacity of about 150 alluvial soil samples was determined. In general, increases in the cation exchange capacities of soil samples correlated with increases in the smaller size fractions, especially soil particles smaller than $53-\mu \mathrm{m}$ diam. Thus, profiles of severely eroded, moderately eroded, and minimally eroded soils usually demonstrated cation exchange capacities of 20-40, 40-100, and 110-210 meq per kilogram of soil, respectively. Cation exchange capacity generally increased with soil depth, reflecting increased percentages of silt and clay beneath the $0-25-\mathrm{mm}$ level.

Organic matter in soil is known to react specifically with several heavy metals, and also contributes to the cation exchange capacity of soil. Severely eroded and moderately eroded soj in the canyons contained 0.10-0.20\% organic carbon, except in upper Mortandad Canyon (0-160 $\mathrm{m}$ post-outfall) soils which had organic carbon contents of $0.20-0.45 \%$. Soils exhibiting minimal water erosion had as much as 50 times more organic carbon than more severely water-worked soils. A soil from the 0-25-mm depth of Mortandad Canyon (100 m preoutfall) had an organic carbon content of $5.2 \%$, whereas a severely eroded soil from the pre-outfall station contained $0.10 \%$ organic carbon.

The pH and levels of carbonates in soils fluctuated as a function of distance above and below the waste outfall areas, partially due to alkaline liquid effluents. For example, $\mathrm{pH}$ values in Mortandad Canyon increased from about 5.7 at the pre-outfall station to a maximum value of $\mathbf{9 . 2}$ at $320 \mathrm{~m}$ below the outfall, and then decreased to near the pre-outfall values at post-outfall stations. The $\mathrm{pH}$ changed very little with soil depth. Although soils may contain carbonates of calcium, magnesium, and sodium, carbonate concentrations are expressed as a percentage of calcium carbonate equivalents. Since there are very low carbonate levels in Bandelier tuff, the alluvial soils in the canyons also have low percentages of calcium carbonate equivalent values, e.g., $0.07-0.20 \%$. However, certain soils receiving alkaline wastes in Mortandad Canyon (0-1280 $\mathrm{m}$ post-outfall) and in DP Canyon ( $0-80 \mathrm{~m}$ post-outfall) have calcium carbonate levels as high as $\mathbf{3 . 7 \%}$.
A formal soil survey of the LASL environs to be completed by USDA Soil Conservation Service scientists during early 1974 should provide a detailed data base for future radiation ecology studies and for engineering and waste management operations.

\section{RADIATION DOSE CALCULATIONS}

\section{A. Assumptions}

The dose assessments presented in this section are based on actual environmental monitoring data, as opposed to theoretical calculations of dispersions of radioactive materials. However, uncertainties associated with many of the data require that certain assumptions be made:

1. Critical locations. For making the dose assessments, consideration was given to all of the normally occupied off-site locations. Calculations were made for doses to the general population at locations of maximum exposure in the Los Alamos area and to the total population within $80 \mathrm{~km}$ of the Laboratory. Calculations were not made for the locations of highest potential doses at unoccupied locations along the LASL perimeter (the "fence post" dose), because such calculations would not be meaningful.

2. Affected populations. Every effort was made to use the most realistic data available (including the subtraction of contributions from background radiation) with respect to potential exposure rates and activity concentrations, while still applying very conservative (pessimistic) assumptions regarding exposed populations. No environmental concentrations of radionuclides attributable to LASL operations were detected beyond the immediate vicinity of the Laboratory. Consequently, it was not considered necessary to extend the dose assessments beyond Los Alamos County; for the purposes of these calculations the total dose to the population within a radius of $80 \mathrm{~km}$ is considered equal to the dose to the population of Los Alamos. The population distributions for Los Alamos County used in the dose assessments were based upon 1970 census data and growth factors obtained from the Los Alamos County Planning and Zoning Commission.

3. Calculational methods. The data and methods recommended by the International Commission on Radiological Protection (ICRP) were used for all dose assessments. For the materials of concern at LASL, the results of these calculations are essentially the same as would be obtained if one assumed that the ratio of actual doses to the dose limits given in AECM 0524 were the same as the ratios of measured concentrations to the CGs given in AECM 0524. 


\section{B. External, Penetrating Radiation}

The analysis of external radiation exposures is complicated by the large area and variable topography encompassed by the LASL site and the off-site areas. TLD stations range from 1.7 to $2.8 \mathrm{~km}$ in elevation; some are located on mesas, others are in canyons. Each major grouping of stations (off-site, perimeter, and on-site) and each functional subgroup (e.g., the Los Alamos community) exhibits a significant range of dose rates as a result of the variability of local conditions.

The highest annual average dose recorded by TLDs at an occupied off-site location was at Cumbres Junior High School (N140 E130). This dose was $226 \mathrm{mrem}$, or 73 mrem above the average background of $153 \mathrm{mrem}$ for all off-site stations situated above $2 \mathrm{~km}$. There are two reasons, however, for rejecting this dose measurement as either a valid average for the school or as representing a LASL contribution to an off-site dose. First, the other TLDs in the Los Alamos community, including several near the LASL boundary (Fig. 3), did not register abnormal doses; and second, the TLD at Cumbres School was located near a brick wall which apparently contains a higher-than-normal concentration of natural radioactivity. To obtain a more valid dose measurement at Cumbres Schocl during 1974, the TLD has been moved from the brick wall to a more representative position.

The most reasonable population dose estimate that can be derived from the TLD data is based on a comparison of the average annual dose in the Los Alamos community with the average annual dose recorded by all off-site stations situated at elevations above $2 \mathrm{~km}$ (see Table III). An annual average dose of 2 mrem above background was detected in the Los Alamos community. This net increase would represent approximately $1 \%$ of the annual population dose limit $(170 \mathrm{mrem})$ if statistically significant. It can be seen from Table III, however, that the uncertainty involved in the external radiation exposure measurements is much greater than the 2 mrem per year difference. Consequently, a calculated population dose is not considered statistically significant.

\section{Airbome Tritium}

The dose resulting from continuous inhalation of tritiated water vapor was calculated using the following equation:

$$
D(t)=51 \mathrm{Cl}_{2} \mathrm{f}_{2} \mathrm{Et} / \lambda \mathrm{m},
$$

where:

$$
\begin{aligned}
\mathrm{D}(\mathrm{t})= & \text { dose equivalent delivered during continuous } \\
& \text { exposure time } \mathrm{t}(\text { days }), \text { in rem } \\
51= & \frac{\left(1.6 \times 10^{6} \mathrm{erg} / \mathrm{MeV}\right)\left(8.64 \times 10^{4} \mathrm{~s} / \mathrm{dav}\right)\left(3.7 \times 10^{4} \mathrm{dis} / \mathrm{s}-\mu \mathrm{Ci}\right)}{100 \mathrm{erg} / \mathrm{g}-\mathrm{tad}} \\
\mathrm{C}= & \text { average airborne concentration, in } \mu \mathrm{Ci} / \mathrm{m} \ell \\
\mathrm{I}_{\mathrm{a}}= & \text { average air intake rate } \\
= & \left.2 \times 10^{7} \mathrm{~m} \ell / \text { day (Ref. } 4\right) \\
\mathrm{f}_{\mathrm{a}}= & \text { fraction of inhaled material reaching organ of } \\
& \text { interest } \\
= & 1 \text { for tritium (oxide) (Ref. } 4) \\
\mathrm{E}= & \text { effective energy deposition per disintegration, } \\
& \text { including the quality factor for dose equivalent } \\
& \text { conversion } \\
= & 0.010 \mathrm{MeV}-\mathrm{rem} / \text { dis-rad (Refs. } 4,5, \text { and } 6) \\
\mathrm{t}= & \text { duration of exposure, in days } \\
\lambda= & \text { effective elimination rate, in day }{ }^{-1} \\
= & 0.069 \text { day } \\
\mathrm{m}= & \text { mass of organ of interest, in } \mathrm{g} \\
= & \left.4.3 \times 10^{4} \mathrm{~g} \text { for body water (Ref. } 4\right)
\end{aligned}
$$

Therefore:

$$
D(t)=1.2 \times 10^{6} \mathrm{C} \text {. }
$$

The average annual concentration of airborne tritiated water vapor for all off-site locations was $(12 \pm 6) \times 10^{-12} \mu \mathrm{Ci} / \mathrm{m} \ell$. The highest average concentration of tritiated water vapor measured at an occupied off-site location was $(113 \pm 40) \times 10^{-12} \mu \mathrm{Ci} / \mathrm{m} \ell$ at the Los Alamos Airport. The background concentration of tritium would result in a whole body dose of approximately $0.014 \mathrm{mrem}$ per year, and the additional $100 \times 10^{-12} \mu \mathrm{Ci} / \mathrm{m} \ell$ observed at the airport would contribute an additional 0.12 mrem per year. This represents less than $0.03 \%$ of the annual dose limit for an individual member of the public and less than $0.1 \%$ of the dose limit for a population group. For the 200 people estimated to reside in the immediate vicinity of the Los Alamos Airport, the calculated population dose contribution would be 0.02 man-rem.

The most reasonable estimate of the dose contribution to the Los Alamos communicy from airborne tritiated water vapor was obtained by averaging the annual concentrations measured at eight locations in the Los Alamos community (station nos. 4, 5, 6, 8, 9, 10, 19, and 20). This average concentration was $18 \times 10^{-12} \mu \mathrm{Ci} / \mathrm{m}$ l. For White Rock and Pajarito Acres area (station nos. 11 and 12) the average concentration was $17 \times 10^{-12} \mu \mathrm{Ci} / \mathrm{m} l$. The net increase of $6 \times 10^{-12} \mu \mathrm{Ci} / \mathrm{ml}$ above the average background concentration resulted in additional dose of 0.007 mrem for the year. For the 17000 residents of Los Alamos County the resulting population dose was calculated to be 0.12 man-rem. 


\section{Airborne Uranium}

Although uranium analyses were performed routinely on a large number of the air sample filters, the majority of the results were less than or equal to the minimum detection limit of $1 \times 10^{-10} \mu \mathrm{g} / \mathrm{m} \ell$. No effort was made to determine the solubility of the uranium collected on air filters because the quantities were so small. The recommended concentration limits (by the ICRP) for individual members of the public are $3 \times 10^{-12} \mu \mathrm{Ci} / \mathrm{m} \ell$ for soluble uranium and $2 \times 10^{-12} \mu \mathrm{Ci} / \mathrm{m} \ell$ for insoluble uranium particles. $^{4,5}$ Based upon the isotopic composition of natural uranium, which is very similar to uranium that might be released by LASL, the cunversion to a mass concentration is $0.33 \mu \mathrm{Ci} / \mathrm{g}$. This conversion results in mass CGs of $9 \times 10^{-6}$ and $6 \times 10^{-6} \mu \mathrm{g} / \mathrm{ml}$, for soluble and insoluble forms of uranium, respectively. Because the CGs for natural uranium (and uranium of similar isotopic composition) are based on chemical toxicity rather than radiotoxicity, and because the measured concentrations were lower than $0.003 \%$ of the CGs, dose calculations were not made for contributions from airborne uranium.

\section{E. Airborne Plutonium and Americium}

Measurements were made of ${ }^{238} \mathrm{Pu}$ and ${ }^{239} \mathrm{Pu}$ on monthly composites of all filters from each air sampling station. Measurements of ${ }^{241} \mathrm{Am}$ were made on filters from only a few selected locations. The annual average concentration of ${ }^{239} \mathrm{Pu}$ for all off-site stations combined was $21 \times 10^{-18} \mu \mathrm{Ci} / \mathrm{m} \ell$. This average value is in good agreement with data reported from the Radiation Alert Network of the Environmental Protection Agency. ${ }^{7}$ For ${ }^{238} \mathrm{Pu}$, the annual average concentration for all off-site locations was calculated to be $15 \times 10^{-18} \mu \mathrm{Ci} / \mathrm{ml}$; this value is approximately a factor of 8 larger than that reported by EPA from the Radiation Alert Network. For ${ }^{241} \mathrm{Am}$, the annual average concentration for 5 off-site locations was found to be $8 \times 10^{-18} \mu \mathrm{Ci} / \mathrm{ml}$, compared to $5 \times 10^{-18} \mu \mathrm{Ci} / \mathrm{ml}$ for 7 perimeter and on-site stations. The EPA Radiation Alert Network does not report ${ }^{241} \mathrm{Am}$ concentrations.

Because of the large variations exhibited in our ${ }^{238} \mathrm{Pu}$ and ${ }^{241} \mathrm{Am}$ data, and because our analytical sensitivities are apparently not as low as those obtained by the EPA Radiation Alert Network, the dose calculations for inhaled actinides were made using the following estimates of global fallout concentrations: $15 \times 10^{-18} \mu \mathrm{Ci} / \mathrm{m} \ell$ for ${ }^{239} \mathrm{Pu}$ and $2 \times 10^{-18} \mu \mathrm{Ci} / \mathrm{m} \ell$ for both ${ }^{238} \mathrm{Pu}$ and ${ }^{241} \mathrm{Am}$. The use of these values, in lieu of our own data, results in somewhat higher calculated net concentrations and correspondingly larger calculated doses.
Lung dose calculations were made for potential inhalation of the actinides, and were based upon the following assumptions:

1. All of the airborne plutonium and americium was highly insoluble and therefore behaved according to the model for Class Y materials, as defined by the ICRP. Task Group on Lung Dynamics.

2. All of the airborne plutonium and americium particles were in the size range of $0.01-$ to $0.1-\mu \mathrm{m}$ diam, for which deposition in the pulmonary region is maximum. ${ }^{8}$

The following equation was used to calculate lung doses resulting from inhalation of plutonium or americium:

$$
D(t)=51 C_{a} f_{a} f_{r} E t / \lambda m\left(1-\frac{1-e^{-\lambda t}}{\lambda t}\right)
$$

where:

$f_{a}=0.7$ (max) for the pulmonary region (Ref. 8)

$f_{r}=$ fraction of pulmonary deposition undergoing long-term retention

$=0.6$ for actinides (Class $\mathrm{Y}$ ) (Ref. 8 )

$E=53 \mathrm{MeV}$-rem/dis-rad for ${ }^{239} \mathrm{Pu}$

$=57 \mathrm{MeV}$-rem/dis-rad for ${ }^{238} \mathrm{Pu}$

= $57 \mathrm{MeV}$-rem/dis-rad for ${ }^{241} \mathrm{Am}$ (Ref. 4)

$\lambda=$ mean clearance rate, in day ${ }^{-1}$

$=0.0014$ day $^{-1}$ for actinides (Class $\mathrm{Y}$ ) from the pulmonary region (Ref. 9)

$\mathrm{m}=1000 \mathrm{~g}$ for the lungs (Ref. 4).

All other quantities are as defined previously for the airborne tritium calculation.

Therefore:

$$
\begin{aligned}
D(365 \text { days }) & =2.4 \times 10^{10} \mathrm{CE} \\
& =1.3 \times 10^{12} \mathrm{C} \text { for }{ }^{239} \mathrm{Pu} \\
& =1.4 \times 10^{12} \mathrm{C} \text { for }{ }^{238} \mathrm{Pu} \\
& =1.4 \times 10^{12} \mathrm{C} \text { for }{ }^{241} \mathrm{Am}
\end{aligned}
$$

Because many of the factors involved in the above equation and the measurements of airborne concentrations are valid to only one significant figure, the following dose calculations have been rounded off accordingly. 
Only five locations in the Los Alamos community exhibited concentrations of airborne actinides significantly in excess of those expected from global fallout. Since the combined concentrations of actinides did not vary by more than a factor of 2 among these five locations, a separate calculation was not made for the highest dose at an occupied off-site location. The combined annual average net concentration of the actinide elements, and the calculated annual lung dose resulting from continuous inhalation of these concentrations, were:

\begin{tabular}{lcc}
\multicolumn{1}{c}{ Location } & $\begin{array}{c}\text { Combined } \\
\text { Avg Net C } \\
(\mu \mathrm{Ci} / \mathrm{m} \ell)\end{array}$ & $\begin{array}{c}\text { Calculated } \\
\text { Annual Lung } \\
\text { Dose (rem) }\end{array}$ \\
\cline { 1 - 1 } 4 Barranca School & $70 \times 10^{-18}$ & $9 \times 10^{-5}$ \\
5 Arkansas Avenue & $50 \times 10^{-18}$ & $5 \times 10^{-5}$ \\
8 Cumbres School & $40 \times 10^{-18}$ & $4 \times 10^{-5}$ \\
9 Diamond Drive & $40 \times 10^{-18}$ & $5 \times 10^{-5}$ \\
10 Fuller Lodge & $70 \times 10^{-18}$ & $10 \times 10^{-5}$
\end{tabular}

The dose limit to the lungs for any individual in the population is $1.5 \mathrm{rem} /$ year (AECM 0524); the maximum dose calculated above was approximately $0.007 \%$ of that limit. The average dose limit to the lungs in a population group is $0.5 \mathrm{rem} /$ year (AECM 0524); for the population represented by the five locations listed above, the average calculated dose was approximately $0.01 \%$ of the population dose limit.

\section{F. Other Nuclides and Pathways}

Tritium, uranium, and transuranic nuclides are the only significant radioactive materials released from LASL facilities. Although some short-lived radionuclides are rountinely measured in Laboratory effluents, they are not detectable in environmental media. The potential doses from these other nuclides are orders of magnitude smaller than the doses from the nuclides evaluated in the preceding sections, and consequently are not considered in the overall dose assessment.

Liquid effluents per se do not flow beyond the LASL boundary but are absorbed in the alluvium of the receiving canyons; excess moisture is lost primarily by evapotranspiration. These effluents are monitored at the points of discharge and in the alluvium of the canyons below the outfalls. Small quantities of radioactive contaminants have been measured in canyon sediments beyond the LASL boundary, probably transported there during periods of heavy run-off. However, no pathways from the sediments to humans have been identified.

No radioactivity in excess of normal background concentrations was detected in drinking water, surface water, or ground water at any off-site location. There are no significant aquatic pathways or food chains to humans in the local area. Consequently, no potential dose contributions beyond those already discussed could be identified or evaluated.

\section{G. Dose Assessment Summary}

The whole-body dose consists of the contributions from external, penetrating radiation and inhaled tritiated water vapor. The whole-body dose must be added to internal dose to obtain the total dose to a critical organ.

As was pointed out earlier, although the TLD data indicated an average external radiation exposure rate of 2 mrem per year in the Los Alamos community above the background measured at other off-site locations, this value was not statistically significant. The only wholebody dose assessment considered to be realistic is that resulting from inhaled tritiated water vapor; the estimated dose contribution from this source was approximately 0.012 mrem per year to a population of 200 people and 0.007 mrem per year to the remaining 17000 residents of Los Alamos County. The total population dose from tritiated water vapor was calculated to be 0.02 plus $0.12=0.14$ man-rem.

Concentrations of actinides in excess of those expected from global fallout were detected at only five occupied off-site locations. The calculated dose to the lungs of any individual continuously exposed in these locations ranged from (4 to 10) $\times 10^{-5}$ rem per year. Since the location of the highest concentration of tritiated water vapor was not the same as any of the locations exhibiting excess concentrations of plutonium or americium, these maximum doses were not additive.

The largest calculated dose that could have been received by any individual beyond the LASL boundary as a result of LASL operations was less than $0.03 \%$ of the annual dose limit; this would have been due to airborne tritium in the vicinity of the Los Alamos Airport. The average dose to all Los Alamos residents resulting from LASL operations was less than $0.002 \%$ of the individual dose limit, or $\mathbf{0 . 0 0 5 \%}$ of the population dose limit. 


\section{CHEMICAL AND BIOLOGICAL QUALITY OF LIQUID EFFLUENTS}

\section{A. Industrial Wastes}

Because the TA-50-1 and TA-21-257 operations are directed prinarily toward removing radioactivity from industrial wastes, the overall chemical quality of the effluents frequently fails to meet drinking water standards. The data in Table XIX, reflecting the quality of effluents from the two plants, show that as the list of "toxic pollutants" pertinent to Public Law 92-500 (Federal Water Pollution Control Act Amendments of 1972) is expanded, measures may be required to improve the quality of the effluents.

\section{B. Domestic Wastes}

The effluent from each major technical area sewage treatment facility is analyzed twice a month by $\mathrm{Zia}$ Company* personnel to evaluate the performance of the plant. The results are shown in Table XX, along with the appropriate standards established by the Environmental Protection Agency (EPA). In general the plants are performing very satisfactorily, but fecal coliform standards are not

The Zia Company is the primary service contractor to the AEC at Los Alamos.

\section{TABLE XIX}

\section{CHEMICAL QUALITY OF MAJOR INDUSTRIAL LIQUID EFFLUENTS}

\begin{tabular}{|c|c|c|c|c|c|c|c|c|c|}
\hline Facility(Location): & & & & $T A-50<N$ & $130 \pm 931$ & & $-21-257$ (1) & N $82 \quad$ E169) & \\
\hline Total Volume Discharged(Rec & eiving & Canyon) & & $53.1 \mathrm{Ml}$ & (Mortandad) & & $M R(D P-L$ & os Alamos) & \\
\hline Analyses ${ }^{a}$ & $\underline{\text { Units }}$ & MOL & Min & $\operatorname{Max}$ & $\operatorname{Av}( \pm 2$ S.D. $)$ & Min & Mex & $\operatorname{Av}( \pm 2$ S.D.) & \\
\hline Sodium & $\mathrm{mg} / \ell$ & 1 & 95 & 1125 & $310( \pm 412)$ & 250 & 645 & $436 \vdots \pm 186 \quad$ & ) \\
\hline Calcium & $m g / \ell$ & 2 & 4 & 116 & $33( \pm 70)$ & 4 & 112 & $24( \pm 33)$ & 1 \\
\hline Magnesium & $m g / \ell$ & 1 & 1 & 18 & $5( \pm 7)$ & 1 & 19 & $5( \pm 6)$ & 1 \\
\hline Fluoride & $\mathrm{mg} / \mathrm{l}$ & 0.1 & 0.2 & 5.5 & $1.5( \pm 1.9)$ & 3 & 149 & $28( \pm 54)$ & ) \\
\hline Chloride & $m g / l$ & 1 & 20 & 125 & $60( \pm 54)$ & 20 & 163 & $75( \pm 74)$ & ) \\
\hline Ammonia & $m g / \ell$ & 0.1 & 0.7 & 189 & $15( \pm 83)$ & 1.2 & 18 & $7( \pm 10)$ & ) \\
\hline Nitrate & $m g / \ell$ & 0.4 & 27 & 2093 & $310( \pm 818)$ & 31 & 1087 & $411( \pm 442)$ & ) \\
\hline Phenolphthaiein Alkalinity & $m g / \ell$ & 3 & 0 & 280 & $52( \pm 144)$ & 0 & 230 & $73( \pm 118)$ & ) \\
\hline Total Alkalinity & $\mathrm{mg} / \mathrm{l}$ & 3 & 60 & 860 & $331( \pm 316)$ & 347 & 1020 & $695( \pm 320)$ & ) \\
\hline Phosphate & $\mathrm{mg} / \mathrm{l}$ & 0.03 & 0.1 & 0.9 & $0.3( \pm 0.4)$ & 0.1 & 34 & $2.1( \pm 11.8)$ & \\
\hline Total Hardness & $\mathrm{mg} / \ell$ & - & 30 & 300 & $105( \pm 170)$ & 16 & 300 & $83( \pm 86)$ & 1 \\
\hline Total Solids & $\mathrm{mg} / \mathrm{l}$ & - & 578 & 4034 & $1148 \quad( \pm 1394)$ & 1260 & 2670 & $1790( \pm 646)$ & ) \\
\hline Conductance & $\mathrm{mS} / \mathrm{m}$ & - & 68 & 580 & $163( \pm 184)$. & 157 & 337 & $225( \pm 39)$ & ) \\
\hline Chemical Oxygen Demand & $\mathrm{mg} / \mathrm{l}$ & 8 & 8 & 97 & $38( \pm 32)$ & 10 & 128 & $57( \pm 58)$ & ) \\
\hline $\mathrm{pH}$ & - & - & 7.1 & 11.7 & - & 7.1 & 10.6 & - & \\
\hline Cedmium & $\mu g / \ell$ & 1 & $<1$ & 560 & $36( \pm 120)^{k}$ & 1 & 500 & $28( \pm 94)^{t}$ & )$^{b}$ \\
\hline Hexavalent Chromium & $\mu g / \ell$ & 4 & $<4$ & 65 & $<13( \pm 26)$ & $<4$ & 7 & $<5( \pm 1)$ & ) \\
\hline Totel Chromium & $\mu g / \ell$ & 4 & $<4$ & 220 & $<27( \pm 70)$ & $<4$ & 380 & $<34 \quad( \pm 140 \quad)$ & 1 \\
\hline Copper & $\mu g / \ell$ & 2 & $<2$ & 5280 & $<320 \quad( \pm 1460)$ & $<2$ & 1500 & $<150( \pm 400)$ & \\
\hline Mercury $^{c}$ & $\mu g / \ell$ & 0.02 & 1 & 149 & $16( \pm 72)$ & $<0.02$ & 25 & $1.7( \pm 9.8)$ & \\
\hline Lead & $\mu g / \ell$ & 0.1 & $<0.1$ & 2600 & $<415 \quad( \pm 1360)$ & $<0.1$ & 1300 & $<510 \quad( \pm 1680)$ & \\
\hline Zinc & $\mu g / \ell$ & 2 & $<2$ & 260 & $<34( \pm 100)$ & $<2$ & 1120 & $<270( \pm 460)$ & \\
\hline
\end{tabular}

\footnotetext{
${ }^{a}$ Fifty-two samples, each a composite of one week's effluent, were analyzed.

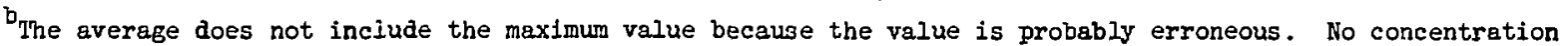
of such magnitude was detected in the plant influent.

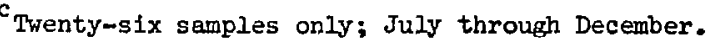


TABLE XX

BIOLOGICAL QUALITY OF SEWAGE EFFLUENTS

\begin{tabular}{|c|c|c|c|c|c|c|c|c|c|c|c|c|}
\hline \multirow[b]{2}{*}{ Plent } & \multirow[b]{2}{*}{ Iocation } & \multicolumn{3}{|c|}{ BOD $(\operatorname{mg} / \ell)$} & \multicolumn{3}{|c|}{ Buspended Solldo (mg/ll) } & \multicolumn{2}{|c|}{ 炟. } & \multicolumn{3}{|c|}{ Fecel Collfors (Ho.1100 me) } \\
\hline & & H1n & Max & $\begin{array}{l}\text { Mrith } \\
\text { Mean }\end{array}$ & 씨고 & Max & $\begin{array}{l}\text { Arith } \\
\text { Mean }\end{array}$ & $\mathrm{MLn}$ & Hax & $M I_{1}$ & $\underline{\operatorname{Hax}}$ & $\begin{array}{l}\text { Geom } \\
\text { Kenn }\end{array}$ \\
\hline TA-3 & $770 \mathrm{E} 35$ & 5 & $\overline{19}$ & $\overline{11( \pm 9)^{n}}$ & $\overline{4}$ & $\overline{18}$ & $8( \pm 7)^{n}$ & $\overrightarrow{7 . n}$ & $\overline{8.0}$ & $\overline{100}$ & $\overline{80000}$ & $4 \longdiv { 2 7 0 0 }$ \\
\hline$T A-\theta$ & $15 * 10$ & & & $10(112)$ & & & $29( \pm 31)$ & 8.0 & 8.5 & - & - & - \\
\hline$T n-16$ & $840 \vee 20$ & 2 & 40 & $7( \pm 16)$ & 3 & 20 & $6( \pm 7)$ & 1.0 & 9.0 & 100 & 4900 & 940 \\
\hline$x A-18$ & 890 E240 & 5 & 50 & $19( \pm 24)$ & 10 & 60 & $16( \pm 22)$ & 8.6 & 10.0 & - & . & - \\
\hline In-21 & 80 E170 & 6 & 64 & $31( \pm 32)$ & 10 & 60 & $22( \pm 23)$ & 6.8 & 8.0 & 600 & 10000 & 2050 \\
\hline $2 x-42$ & $185=90$ & 7 & 31 & $20( \pm 15)$ & 5 & 25 & $11( \pm 24)$ & 6.9 & 8.5 & 0 & 0 & 0 \\
\hline$T h-53$ & $x \quad 50 \quad: 225$ & 9 & 210 & $29( \pm 67)$ & 5 & 120 & $23(240)$ & 8.0 & 10.5 & 8 & 43000 & 1900 \\
\hline EPA Ete & rad $a_{\text {(Monthl }}$ & & - & 30 & - & - & 30 & 6.0 & 9.0 & - & - & 200 \\
\hline
\end{tabular}

Tralos in parentheses represents 2 standard deviations of the sean.

byo cha Part 133, Beconders Treatenent Infornation.

being met because the effluents, with the exception of those from TA-3 and TA-41, are not chlorinated. Efforts are being made to provide this chlorination.

The $\mathrm{pH}$ of effluents from the TA-18 and TA-53 lagoon systems is often higher than the EPA upper limit of 9.0, but may actually be lower than indicated because most of the measurements were made with a color comparator. Future data should be more accurate. Although effluents from lagoons typically have a higher $\mathrm{pH}$ than effluents from treatment plants, an investigation will be conducted to determine whether unknown industrial wastes are magnifying the problem.

The unusually high $\mathrm{pH}$ of the TA-53 effluent occurred in June when the system was not functioning properly because the east lagoon had become anaerobic for some reason. The system soon regained its normal condition.

Effluents from the sewage treatment facilities were also analyzed for chemical quality to verify that significant amounts of chemicals were not escaping from LASL facilities through the sanitary sewage systems. The data in Table XXI indicate that the chemical quality of the municipal plants is typical of domestic sewage and, as would be expected with a more dilute influent than that of municipal sewage, the average concentrations for the technical area effluents are lower. Nitrate concentrations are the only exception. However, the maximum value of $173 \mathrm{mg} / \mathrm{k}$, observed at the TA-18 lagoon, is not atypical for a grab sample from a lagoon.

\section{TABLE XXI}

\section{CHEMICAL QUALITY OF EFFLUENTS FROM SEWAGE TREATMENT PLANTS}

Areas Served(lio, of Samples):

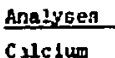

Magnestun

Sod! un

Carbonate Alkalinity

Blcarbonate Alkailatly

Chloride

Fuoride

Hitrate

Total Sol148

Totel Hardreos

Conductance

\begin{tabular}{|c|c|}
\hline \multirow[b]{2}{*}{ Units } & Munic \\
\hline & Minimu \\
\hline$m g / e^{n}$ & 11 \\
\hline $\mathrm{mg} / \mathrm{l}$ & 1 \\
\hline$m g / \ell$ & 63 \\
\hline$m g / e$ & 0 \\
\hline$m_{3} / l$ & $10 B$ \\
\hline$m g / l$ & 32 \\
\hline $\mathrm{mg} / \mathrm{l}$ & 1.9 \\
\hline$m g / e$ & 2.2 \\
\hline$m g / l$ & 432 \\
\hline$m g / l$ & 40 \\
\hline$m s, i m^{b}$ & 42 \\
\hline
\end{tabular}

\footnotetext{
- $1 \mathrm{mg} / \mathrm{l}$ o $1 \mathrm{ug} / \mathrm{ml}=1 \mathrm{ppm}$.

b $1 \mathrm{~ms} / \mathrm{m}$ Imiclisiemens per metrel 10 umho/ cm.

c Yalue In parentheses represents 2 standard deviations of the wean.
}

\begin{tabular}{ccr}
\multicolumn{3}{c}{ Technical Areas (11 aamples) } \\
\hline Mlninum & Maximum & \multicolumn{1}{c}{ Mean } \\
\hline 6 & 9 & $14( \pm 8)^{c}$ \\
0 & 5 & $2( \pm 4)$ \\
13 & 101 & $47( \pm 60)$ \\
0 & 12 & $2( \pm 10)$ \\
48 & 160 & $88( \pm 66)$ \\
10 & 44 & $24( \pm 20)$ \\
0.5 & 5 & $3( \pm 2)$ \\
0 & 173 & $44( \pm 118)$ \\
176 & 470 & $308( \pm 188)$ \\
16 & 64 & $44( \pm 27)$ \\
16 & 58 & $31( \pm 26)$
\end{tabular}


In the early days of LASL, many Laboratory effluents were simply routed to a canyon edge and discharged. The practice was stopped long ago, but many of the effluent residues still exist. None is known to contain radioactivity, but the chemical quality is generally unknown. In late 1973 a plan was initiated to locate, sample, and analyze these effluents to identify needs for waste treatment. Although data are incomplete, early indications are that these effluents will not present major problems.

Problems will be encountered at TA-16, where several effluent streams containing barium and explosives residues are discharged to the environment with sedimentation used as the only treatment process. Studies have indicated that these pollutants migrate very slowly, that residuals in soils near the outfalls pose no health or safety threat, and that the contaminants are contained well within the LASL site. TA-16 is the non-radioactive waste area needing the most attention.

Other waste inanagement problems may exist (or develop as a consequence of Public Law 92-500) at the 2 l-odd cooling water towers scattered throughout the technical areas. The release of corrosion inhibitors and algaecides may require attention. Investigation of these problems also began during 1973 and is continuing.

\section{CHEMICAL QUALITY OF SURFACE AND GROUND WATERS}

\section{A. Regional Surface Waters}

Regional rivers and reservoirs within $75 \mathrm{~km}$ of LASL (Fig. 8) were sampled to provide data on the chemical quality of water in the area. The average concentrations listed in Table XXII represent one sample each from Abiquiu, Caliente River, Santa Cruz Reservoir, Tesuque Creek, Galisteo Reservoir, Bernalillo, Jemez Reservoir, Jemez Creek, and Fenton Lake; two samples each from Chamita and Embudo; and three samples each from Otowi and Cochiti.

The mineral concentrations in water samples from Jemez and Galisteo Reservoirs were slightly lower than those observed in CY 72 because of dilution by greater volumes of run-off. There were no significant changes in the quality of waters from the remaining stations.

\section{B. Perimeter Surface and Ground Waters}

Perimeter surface and ground water samples were collected at six locations on the Pajarito Plateau (Table

\section{CHEMICAL QUALITY OF REGIONAL SURFACE WATERS}

\begin{tabular}{|c|c|c|c|c|}
\hline \multirow[b]{2}{*}{ Anelys is } & \multicolumn{3}{|c|}{ Concentretions $(\mathrm{mg} / \mathrm{e})$} & \multirow[b]{2}{*}{$2 \operatorname{sta}^{b}$} \\
\hline & Min & $\operatorname{Max}$ & $\mathrm{AVg}^{\mathrm{B}}$ & \\
\hline Bicarbonate & 40 & 328 & 116 & - \\
\hline Calcium & 14 & 205 & 49 & - \\
\hline Carbonate & 0 & 0 & 0 & - \\
\hline Chloride & 2 & 158 & 20 & - \\
\hline Fluoride & $<0.1$ & 2.1 & 0.4 & 240 \\
\hline Magnesium & 3 & 52 & 10 & - \\
\hline Nitrate & $<0.4$ & 2.6 & 0.9 & 2 \\
\hline Sodium & 7 & 168 & 35 & - \\
\hline TDS & 110 & 1536 & 387 & 35 \\
\hline Hardness & 48 & 724 & 176 & - \\
\hline $\mathrm{pH}$ & 7.3 & 8.8 & & - \\
\hline $\begin{array}{l}\text { Conductance } \\
(m S / m)^{c}\end{array}$ & 9 & 164 & 43 & - \\
\hline
\end{tabular}

XXIII and Fig. 10) and at 27 locations in White Rock Canyon (Fig. 9). The chemical quality of these waters has not changed from previous reporting periods. These waters are of good enough quality to be used for domestic or municipal supplies, but are not so used. The one exception was obtained from the mouth of Mortandad Canyon, where effluent from the Los Alamos County White Rock Sewage Treatment Plant is discharged and the fluoride concentration is $8.1 \mathrm{mg} / \mathrm{l}$.

\section{Los Alamos Water Supply System}

The chemical quality of water in the Los Alamos water supply system varies slightly from periods of light production (winter) to periods of heavy pumpage (summer). The quality of sumples from the 16 wells shown in Fig. 10 is presented in Table XXIV. These routine analyses indicate no significant changes in the quality of water. Maximum concentrations were well below the limits defined by the U.S. Public Health Standards for drinking water (see Appendix E), except for fluoride concentrations in water from two of the wells. 
TABLE XXIII

\section{CHEMICALS IN PERIMETER SURFACE AND GROUND WATERS}

\begin{tabular}{|c|c|c|c|c|c|c|c|c|c|c|c|c|c|}
\hline \multirow[b]{2}{*}{ Smpling Locations } & \multirow{2}{*}{$\begin{array}{l}\text { No.\& } \\
\text { Type of } \\
\text { Sample }\end{array}$} & \multicolumn{10}{|c|}{ Chemical Concentrations (mg/l) } & \multirow{2}{*}{$\mathrm{pH}$} & \multirow{2}{*}{$\begin{array}{l}\text { Cond. } \\
(\mathrm{mS} / \mathrm{m})\end{array}$} \\
\hline & & $\mathrm{Ca}^{+2}$ & $\mathrm{Mg}^{+2}$ & $\mathrm{Na}+2$ & $\mathrm{CO}_{3}{ }^{-2}$ & $\mathrm{HCO}_{3}^{-1}$ & $\mathrm{Cl}^{-1}$ & $F^{-1}$ & $\mathrm{NO}_{3}^{-1}$ & $\operatorname{TDS}$ & Hard & & \\
\hline $\begin{array}{l}\text { Guaje Canyon } \\
\text { N215 E315 }\end{array}$ & 1.-S & 11 & 4 & 10 & 0 & 52 & 2 & 0.3 & 0.4 & 138 & 44 & 7.5 & 11.0 \\
\hline $\begin{array}{l}\text { Test We11 } 2 \\
\text { N115 E260 }\end{array}$ & $1-G$ & HI & 1 & 8 & 0 & 52 & 4 & 0.7 & $<0.4$ & 112 & 32 & 7.8 & 9.5 \\
\hline $\begin{array}{l}\text { Los Alamos Res. } \\
\text { N105 W } 75\end{array}$ & $1-s$ & 10 & 6 & 6 & 0 & 32 & 2 & 0.1 & 0.4 & 98 & 48 & 7.0 & 8.5 \\
\hline $\begin{array}{c}\text { Basalt Springs } \\
\text { N } 65 \text { E395 }\end{array}$ & $2-5$ & 27 & 7 & 15 & 0 & 88 & 14 & 0.9 & 9.3 & 263 & 96 & 7.7 & 31.0 \\
\hline $\begin{array}{l}\text { Los Alamos Springs } \\
\text { IN } 60 \text { E405 }\end{array}$ & $2-5$ & 35 & 10 & 19 & 0 & 92 & 22 & 1.2 & 11 & 290 & 128 & 7.6 & 32.0 \\
\hline $\begin{array}{l}\text { Frijoles Canyon } \\
\text { s280 E195 }\end{array}$ & $1-5$ & 10 & 3 & 8 & 0 & 60 & 4 & $<0.1$ & 0.9 & 126 & 36 & 7.6 & 11.0 \\
\hline $\begin{array}{l}\text { White Fock Canyon } \\
\text { of the Rio Grande }\end{array}$ & $\begin{array}{r}32 \\
\text { Min: }\end{array}$ & 10 & $<1$ & 8 & 0 & 56 & 2 & $<0.1$ & $<0.4$ & 130 & 28 & 7.4 & 11.0 \\
\hline ( 27 locations, & Max: & 42 & 9 & 126 & 0 & 384 & 32 & 8.1 & 11 & 506 & 238 & 8.6 & 22.0 \\
\hline see Fig. 9 & Avg: & 22 & 4 & 25 & 0 & 114 & 8 & 0.8 & 2.6 & 226 & 73 & - & 15.0 \\
\hline
\end{tabular}

Stlenium and arsenic concentrations in each of the 16 wells were studied because these elements were reported in well water in 1972. The study was made over a 10-h pumping period, with samples collected at intervals of $0.5,1,2,3,4,6,8$, and $10 \mathrm{~h}$ after pumping began. The pumping period was preceded by a shutdown period of at least $24 \mathrm{~h}$. Tests were made not only to determine concentration levels in the wells but also to determine whether these concentrations changed with pumpage. The Envirosinental Studies Group collected and analyzed 128 samples. To ensure quality control, duplicate samples were analyzed by a commercial laboratory." Results were comparable with limits of analytical accuracy.

All selenium concentrations shown in Table XXV were below the $10-\mu \mathrm{g} / \ell$ U.S. Public Health Standard for drinking water, although a few were above the $1 \mu \mathrm{g} / \ell$ limit of detection. Selenium concentrations did not change with increased pur page.

The maximum arsenic concentrations (Table XXV) in water from wells LA-6 and G-2 exceed the U.S. Public Health Service standard of $50 \mu \mathrm{g} / \mathrm{l}$, violation of which constitutes ground for rejection of the water supply. The arsenic concentration in water from well LA-6 averaged

\footnotetext{
-Controls for Environmental Pollution, Inc, Santa Fr, NM.
}

about $130 \mu \mathrm{g} / \ell$ during the $10-\mathrm{h}$ test. The arsenic concentration in water from well G-2 increased from $8 \mu \mathrm{g} / \ell$ at $0.5 \mathrm{~h}$ after onset of pumping to $52 \mu \mathrm{g} / \mathrm{l}$ at $10 \mathrm{~h}$ after the test began. Arsenic concentrations in the other wells varied slightly but were within permissible limits. Mixing of water in the distribution system dilutes the arsenic concentrations from wells LA-6 and G-2 to levels acceptable for domestic use. The arsenic reported in the analyses occurs naturally and is not the result of Laboratory contamination.

An evaluation of various ions was made in the water distribution system at stations on the main lines above the well fields. The samples represent a mixture of water from the wells in the fields. A commercial laboratory* made analyses for arsenic, barium, cyanide, selenium, silver, copper, iron, zinc, aluminum, nickel, and chromium. The results, shown in Table XXVI, were within acceptable limits for domestic use, with the exception of the selenium concentration reported from Los Alamos Booster. A reanalysis of water from this station indicated selenium concentrations of less than $1 \mu \mathrm{g} / \ell$. The initial analysis was probably erroneous, as watcr from wells in the Los Alamos well field contain no significant amounts of selenium. 
TABLE XXIV

CHEMICALS IN LOS ARAMOS WATER SUPPLIES

\begin{tabular}{|c|c|c|c|c|}
\hline \multirow[b]{2}{*}{ Anelyses } & \multicolumn{3}{|c|}{ Concentrations $(\mathrm{mg} / \mathrm{l})$} & \multirow[b]{2}{*}{ Sta } \\
\hline & Min & Mex & Avg $^{\mathrm{a}}$ & \\
\hline Arsenic & $<0.001$ & 0.133 & 0.027 & 54 \\
\hline Bicarbonate & 40 & 280 & 108 & - \\
\hline Calcium & 5 & 27 & 13 & - \\
\hline Carbonate & 0 & 0 & 0 & - \\
\hline Chloride & 1 & 18 & 6 & - \\
\hline Fluoride & 0.5 & 2.9 & 1.0 & -100 \\
\hline Magnesium & $<1$ & 11 & 3 & - \\
\hline Nitrate & $<0.4$ & 2.6 & 1.3 & 3 \\
\hline Selenium & $<0.001$ & 0.001 & 0.001 & 10 \\
\hline Sodium & 4 & 134 & 35 & - \\
\hline TDS & 104 & 456 & 21.0 & 42 \\
\hline Hardness & 12 & 108 & 45 & - \\
\hline $\mathrm{pH}$ & 7.5 & 8.7 & - & - \\
\hline $\begin{array}{l}\text { Conductance } \\
(\mathrm{mS} / \mathrm{m})^{\mathrm{c}}\end{array}$ & 7 & 54 & 20 & - \\
\hline
\end{tabular}

${ }^{a}$ Average of 20 samples each for As and Se, and 33 samples for all others.

${ }^{b}$ Percent of drinking water standard (EPA and PHS).

$c_{1} \mathrm{~ms} / \mathrm{m}=10 \mathrm{\mu mho} / \mathrm{cm}$.

\section{On-Site Surface and Ground Waters}

1. Nun-Effluent Release Areas. Monitoring of on-site, non-ffluent waters consisted of analyzing one sample each from Cañada del Buey, Pajarito Canyon, Water Canyon, and Test Well DT-5A, and two samples from Test Well 3 (see Fig. 10). Chemical analyses of these samples (Table XXVII) indicate no significant change from previous reporting periods. Although these water sources do not serve as municipal or domestic supplies, they do meet current drinking water standards (Appendix E).

2. Effluent Release Areas. Chemical quality was determined for samples of the alluvium in canyons receiving industrial effluents from TAs. Data for each canyon are presented separately in Table XXVII and can be compared to effluent release data in Table XIX.

Acid-Pueblo Canyon was formerly AEC-LASI- property and received industrial wastes from 1943 to 1964. The chemical quality of samples from this area has not changed noticeably from other post-1964 analyses. The
TABLE XXV

ARSENIC AND SELENIUM IN LOS ALAMOS SUPPLY WELLS

Fieid and Well
Los Alamos Field
LA-18
LA-2
LA-3
LA-4
LA-5
LA-6
Guaje Field
G-1
$G-1 A$
$G-2$
$G-3$
$G-4$
$G-5$
$G-6$

\begin{tabular}{|c|c|c|c|c|c|}
\hline \multicolumn{3}{|c|}{ As $(\mu \mathrm{g} / \mathrm{l})$} & \multicolumn{3}{|c|}{ Se (ngile) } \\
\hline Min & Max & $\underline{A v}^{\mathrm{a}}$ & Nin & Max. & $A v^{a}$ \\
\hline 38 & $4 \pi$ & 42 & $<1$ & 3 & \\
\hline 18 & 23 & 20 & $<1$ & 1 & \\
\hline$<7$ & 10 & 8 & $<3$ & $<1$ & $<1$ \\
\hline 10 & 13 & 12 & $<1$ & $<2$ & $<$ \\
\hline 12 & 29 & 22 & $<1$ & $<1$ & $<$ \\
\hline 122 & 135 & 130 & $<1$ & $<1$ & $<$ \\
\hline 10 & 21 & 14 & $<1$ & 81 & $<1$ \\
\hline 8 & 12 & 10 & $<1$ & $<1$ & $<1$ \\
\hline 8 & 52 & 39 & $<1$ & 1 & \\
\hline$<7$ & 18 & 13 & $<1$ & 6 & \\
\hline$<7$ & 9 & 7 & $<1$ & 2 & 1 \\
\hline$<7$ & 10 & 9 & $<1$ & 2 & 1 \\
\hline 8 & 31 & 12 & $<1$ & 1 & \\
\hline 9 & 21 & 10 & $<1$ & $<1$ & $<$ \\
\hline 8 & 9 & 9 & $<1$ & $<1$ & $<1$ \\
\hline 8 & 10 & 9 & $<1$ & $<1$ & $<1$ \\
\hline
\end{tabular}

Average of 8 semples collected from aech vell during a 10-h pumping test.

high fluoride and total dissolved solids concentrations result from the Pueblo municipal sewage treatment plant effluent.

Chemical analyses from two surface water stations in Sandia Canyon give indication of effluents from the TA-3 sewage treatment plant and cooling water effluents from the TA-3 steam plant. The higher concentrations of chemicals for Sandia Canyon are not unexpected sincc (except for storm or spring run-off) these effluents constitute the total canyon stream.

The chemical quality of surface and ground waters in DP-Los Alamos Canyon reflects the release of industrial sewage and cooling tower effluents from TA-21 and TA-2. In general, the quality of water improves down-gradient from the confluence of $\mathrm{DP}$ and Los Alamos Canyons. The concentrations observed for this reporting pcriod were slightly decreased and probably resulted from the unusually large spring runoff which diluted effluents and recharged the shallow aquifer in the alluvium. 
TABLE XXVI

TRACE MATERIALS IN WATER SOURCES

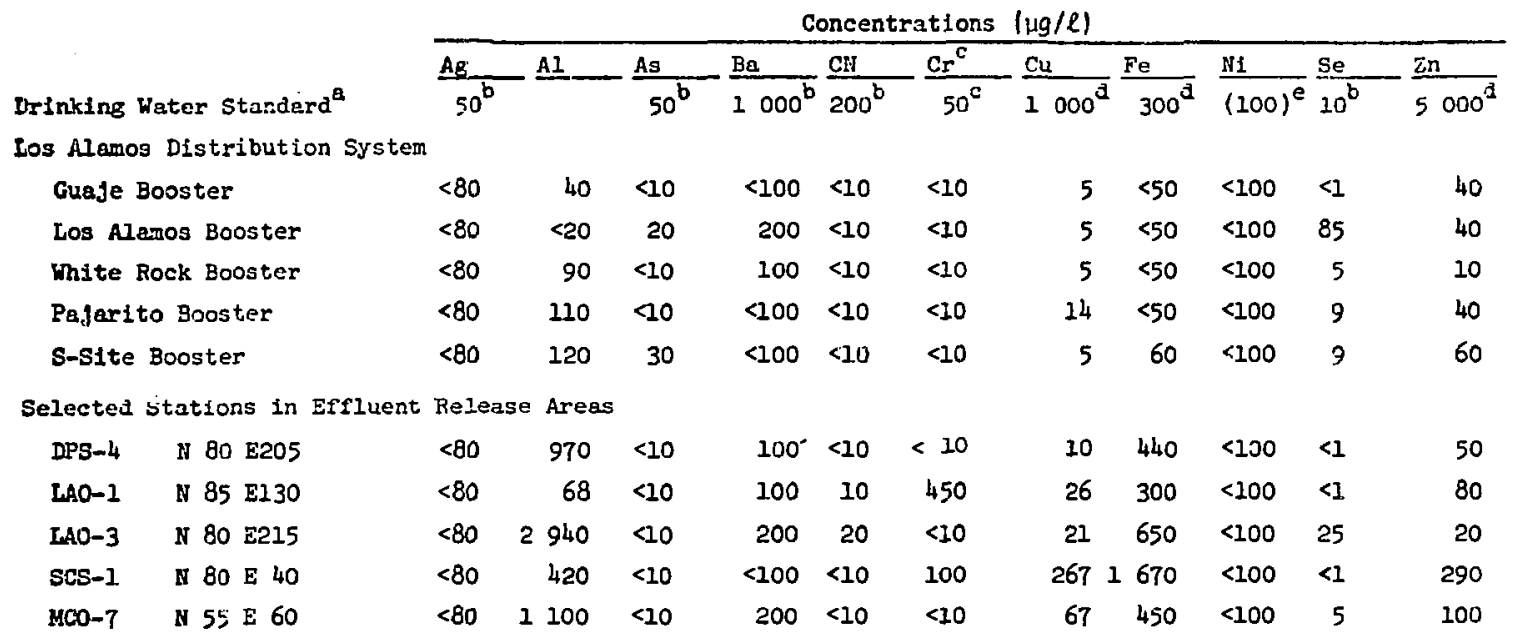

EPA Bulletin 956; PHS Publ. 956; 42 CFR 72.

Bandatory standard

'Standard shown is for hexavalent chromium; measured values represent total chromium.

Recommended standard

Recommended by NITQCC.

Surface and ground waters of Mortandad Canyon are clearly influenced by the chemical discharges from the industrial waste treatment plant at TA-50 (see Sec. X-A).

Analyses for various trace ions were made on one sample each from selected stations in DP-Los Alamos, Sandia, and Mortandad Canyons (see Table XXVI). The selenium concentration reported for the observation hole LAO-3 sample exceeded the USPHS "grounds for rejection" limit for drinking water. However, samples obtained upstream at stations LAO-1 (ground water) and DPS-4 (surface water) contained no detectable selenium, and it is unlikely that the reported selenium soncentration was representative of this sampling station. The chromium concentration reported for LAO-1 exceeded the "grounds for rejection" limit for a drinking water supply, and was caused by cooling tower effluents from an up-gradient TA. The waters from DP-Los Alamos, Sandia, and Mortandad Canyons are not sources of municipal or domestic supply; nevertheless, the trace ion concentrations observed in these canyons are reported in Table XXVI along with concentrations observed in the Los Aiamos supply system. The concentrations can thus be compared to the drinking water standards given in the same table.

\section{METEOROLOGY AND CLMATOLOGY}

\section{A. Objectives}

Meteorological monitoring supports many Laboratory activities, including environmental surveillance, health and safety management, engineering design and operations, and engineering development. The data are important in environmental monitoring, where they serve many purposes, including:

(1) documentation of general environmental conditions including, but not limited to, contributions to physical stress in the working environment (extreine heat, cold, wind, precipitation, etc.),

(2) establishment of a base line for evaluation of climatic modifications caused by l aboratory activities,

(3) providing data for investigating the transport and fate of material released to the atmosphere as a result of routine Laboratory activities,

(4) maintenance of a readiness posture in the event of accidental releases of contaminants to the atmosphere, and

(5) generating a data base for estimating occurrence probabilitics of relatively rare atmospheric phenomena 
TABLE XXV!I

CHEMICAL QUAITTY OF ON-SITE SURFACE AND GROUND WATER SOURCES

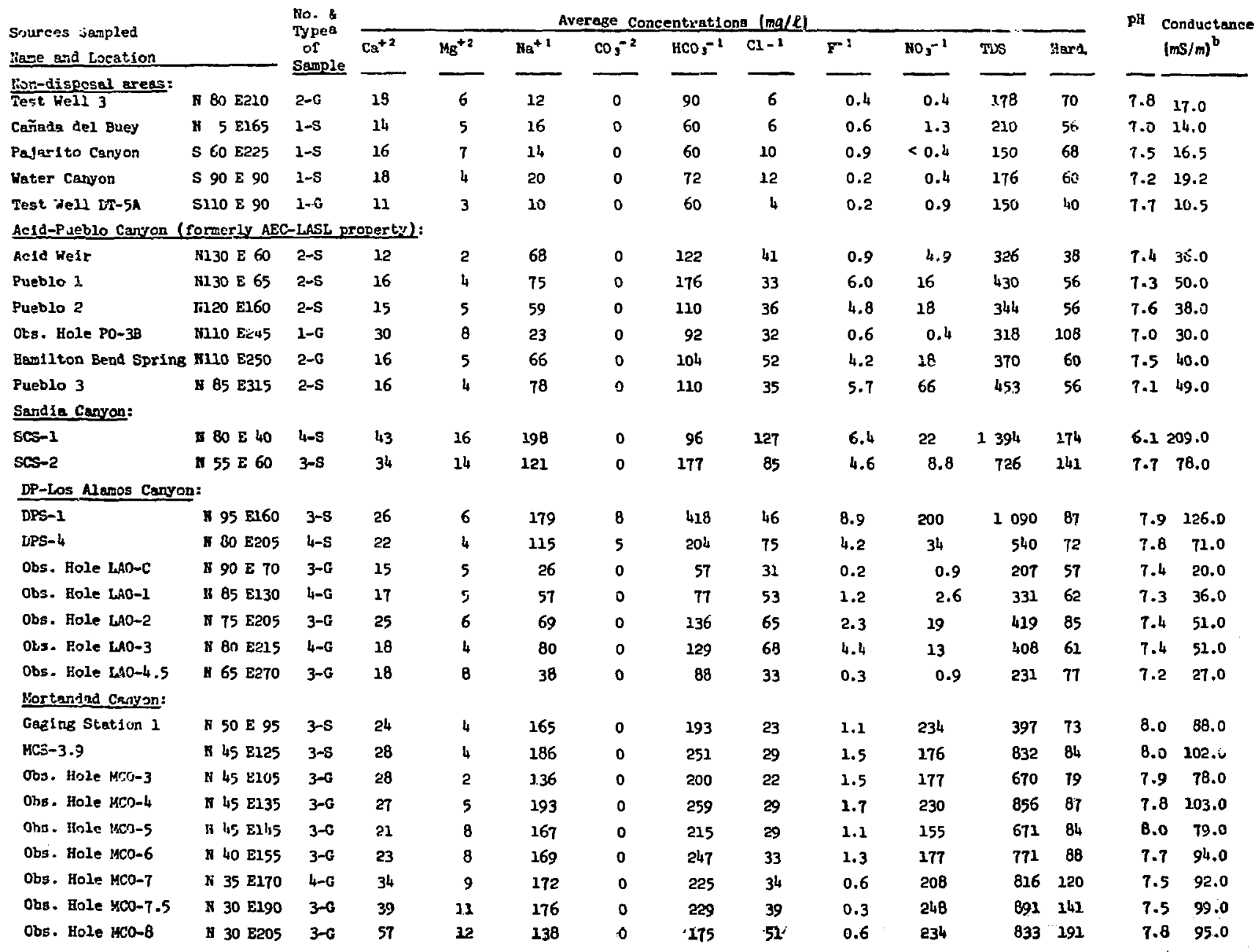

Tumber of vauples anajy zed during 1973; $G$ oround vater; 8 = aurface vater. 
that might affect present or planned facilities and operations.

Data sources exploited for the first time during 1973 were:

(1) wind and temperature profiles measured on a $91-\mathrm{m}$ tower providing the variation of transport wind with height and also indications of the dispersal capacity of the atmosphere,

(2) a network of rain gauges, providing the distribution of daily and monthly precipitation--a valuable input to the hydrology of the canyon-mesa topography of the LASL site, and

(3) a continuously recording pyrheliometer, measuring solar energy flux, valuable in heat transfer estimates for materials handling and engineering design.

Future requirements of the meteorological monitoring system include:

(1) evaporation rates from selected sites, e.g., waste disposal areas,

(2) time and space variation of the transport wind fields and the associated turbulence parameters affecting dispersion rates of contaminants, and

(3) resuspension of contaminants from the ground surface by various mechanisms and in a variety of chemical and physical configurations.
Proceeding concurrently with the evolution of an empirical observation system is the development of physical models to allow the interpretation and generalization of the data collected at a particular location under one set of conditions. The bases for such model development are often available in the literature but must be amended and tailored to the specific application. In other cases, extensive research is required to achieve even a minimal modeling foundation. Interpretive efforts have been initiated in all relevant areas of application and will be discussed briefly in the following sections.

\section{B. Climatological Records}

Tables XXVIII and XXIX show means and extremes of temperature and precipitation for the entire period of record and for 1973 , respectively. The first half of 1973 was cooler than normal, the greatest deviation from average occurring in April when temperatures were $3.6^{\circ} \mathrm{C}$ below normal. Temperatures from August through December were above normal.

Precipitation in 1973, was below average in seven months, near the average in three months, and exceeded the long-term average in March and May. A record was set

\section{TABLE XXVIII}

\begin{tabular}{|c|c|c|c|c|c|c|c|c|c|c|c|c|c|c|c|c|c|}
\hline & & Tenr & teur & $e^{\circ} \mathrm{C}$ & & & & & & & Inltent & an Tot & Glo (m) & & & & \\
\hline & Nes & & & & Extr & emess & & & Raln & & & & & Enov an & d rror & & \\
\hline & Dally & Yalues & & & & & & & & & & & & Frecip & 1 tatlo & & \\
\hline No. & Max & Min & $\begin{array}{l}\text { Yo } \\
\text { Ycan } \\
\end{array}$ & 프드 & $\underline{Y r}$ & L에 & $\underline{x}$ & Mean & $\begin{array}{l}\text { Dally } \\
\text { Mnx }\end{array}$ & $\underline{\mathbf{M r}}$ & $\begin{array}{l}\text { Mo } \\
\text { Mnx }\end{array}$ & $\underline{I r}$ & Mean & $\begin{array}{l}\text { Delly } \\
\text { Max }\end{array}$ & $\underline{\text { Yr }}$ & $\begin{array}{l}\text { Mo } \\
\text { Max }\end{array}$ & Yr \\
\hline Jan & 3.9 & -7.9 & -2.0 & 17.8 & 1963 & -27.8 & 1963 & 20.83 & 62.23 & 2916 & 171.45 & 1916 & 240.7 & 381.0 & 1913 & 989.2 & 1949 \\
\hline Teb & 6.1 & -5.8 & 0.1 & 10.9 & 1936 & -25.6 & 1951 & 17.52 & 26.67 & 1915 & 61.89 & 194,8 & 206.6 & 330.2 & 1915 & 604.5 & 1948 \\
\hline Mar & 9.4 & -3.4 & 3.1 & 21.7 & 1971 & -19.4 & 191,8 & 25.42 & 57.15 & 1916 & 104.4 & 1973 & 262.6 & 457.2 & 1926 & 939.8 & 1973 \\
\hline Agr & 14.6 & 1.0 & 7.8 & 26.7 & 1950 & -15.0 & 1925 & 24.90 & 36.83 & 1969 & 117.86 & 1916 & 204.1 & 304.8 & 1958 & 853.4 & 1958 \\
\hline May & 19.9 & 6.0 & 12.9 & 31.7 & 1935 & -4.4 & 1938 & 32.63 & 45.72 & $19 ? 9$ & $113.5 \mathrm{~h}$ & 1929 & 20.0 & 228.6 & 1917 & 431.8 & 1917 \\
\hline Jил & 25.3 & 10.9 & 18.1 & 33.9 & 1954 & -2.2 & 1919 & 34.99 & 34.80 & 1931 & 141.49 & 1913 & 0 & 0 & -- & 0 & $\ldots$ \\
\hline Jus & 26.9 & 12.9 & 19.9 & 35.0 & 1935 & 2.8 & 1924 & 86.06 & 70.61 & 1968 & 202.69 & 1919 & 0 & 0 & - & 0 & - \\
\hline A.16 & 25.4 & 12.3 & 199 & 33.3 & 1937 & $4 . h$ & 191.7 & 94.45 & 57.40 & 1951 & 283.97 & 1952 & 0 & 0 & $-\infty$ & 0 & - \\
\hline Sep & 22.4 & 8.9 & 25.7 & 34,4 & 1934 & -5.0 & 1936 & 50.13 & 56.13 & 1929 & 247.07 & 2941 & 5.0 & 252.4 & 1913 & $15 c .4$ & 2914 \\
\hline Det & 16.7 & 3.2 & 9.9 & 27.8 & 1930 & -8.9 & 1970 & 40.41 & 88.39 & 2919 & 171.96 & 1957 & 37.5 & 228.6 & 1972 & 228.6 & $\begin{array}{l}1959 \\
1972\end{array}$ \\
\hline Hor & 9.4 & -3.1 & 3.2 & 20.6 & 1937 & -20.0 & 1957 & 17.86 & 37.08 & 1931 & 83.82 & 1957 & 128.1 & 355.6 & 1931 & 876.3 & 1957 \\
\hline Dec & 4.9 & -6.8 & -1.0 & 16.7 & 1933 & -23.3 & 1924 & 23.02 & 34.29 & 1965 & 72.39 & 2965 & 270.4 & 457.2 & 1915 & 1049.0 & 3967 \\
\hline Year & 15.4 & 2.3 & 8.9 & 35.0 & 1939 & -27.8 & 1963 & 464.97 & 60.39 & 1919 & 283.97 & 1952 & 1274.8 & 457.2 & $\begin{array}{l}1915 \\
1916\end{array}$ & .049.0 & 1967 \\
\hline
\end{tabular}

\begin{tabular}{|c|c|c|}
\hline $\begin{array}{l}\text { Prec1p } \\
2.5 .5\end{array}$ & $\begin{array}{l}\text { Max } \\
\text { Tenp } \\
226.7^{\circ} \mathrm{C}^{\circ}\end{array}$ & 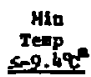 \\
\hline 2 & 0 & $\theta$ \\
\hline 2 & 0 & 6 \\
\hline 3 & 0 & 3 \\
\hline 3 & 0 & 0 \\
\hline 3 & 1 & o \\
\hline 3 & 24 & 0 \\
\hline 8 & 19 & 0 \\
\hline 0 & 12 & 0 \\
\hline 5 & 5 & 0 \\
\hline 3 & 0 & 0 \\
\hline 2 & 0 & 2 \\
\hline 3 & 0 & 6 \\
\hline 45 & 51 & 25 \\
\hline
\end{tabular}

$26.7^{\circ} \mathrm{C}-60^{\circ} \mathrm{ri}-9.4^{\circ} \mathrm{C}-15^{\circ} \mathrm{P}$ 
TABLE XXIX

CLIMATOLOGICAL SUMMARY FOR 1973

\begin{tabular}{|c|c|c|c|c|c|c|c|c|c|c|c|c|}
\hline \multirow[b]{3}{*}{ Month } & \multicolumn{5}{|c|}{ Temperature $\left({ }^{\circ} \mathrm{C}\right)$} & \multicolumn{4}{|c|}{ Prectpitation Total (mm) } & \multirow{2}{*}{\multicolumn{3}{|c|}{ Number of Days }} \\
\hline & \multicolumn{3}{|c|}{ Means } & \multicolumn{2}{|c|}{ Extrones } & \multicolumn{2}{|c|}{ Rain } & \multicolumn{2}{|c|}{$\begin{array}{l}\text { Snow or Frozen } \\
\text { Precinitation }\end{array}$} & & & \\
\hline & $\begin{array}{l}\text { Daily } \\
\text { Mex } \\
\end{array}$ & $\begin{array}{l}\text { Daily } \\
\text { Min } \\
\end{array}$ & Monthly & 軍宛 & Low & Total & $\begin{array}{l}\text { Daily } \\
\text { Mex } \\
\end{array}$ & Total & $\begin{array}{l}\text { Dafly } \\
\text { Max } \\
\end{array}$ & $\begin{array}{l}\text { Precip } \\
\geqq 2.5 \mathrm{~mm}\end{array}$ & $\begin{array}{c}\text { Mex } \\
\text { Temp } \\
\geq 26.7^{\circ} \mathrm{C}^{\mathrm{a}} \\
\end{array}$ & $\begin{array}{c}\text { Min } \\
\text { Temp } \\
\leq-9.4^{\circ} \mathrm{C}^{8} \\
\end{array}$ \\
\hline Jan & 2.1 & -8.7 & -3.3 & 10.0 & -13.3 & 5.8 & 2.3 & 50.8 & - & 0 & 0 & 14 \\
\hline Feb & 4.1 & -6.2 & -1.1 & 12.8 & -13.3 & 17.5 & 5.6 & 101.6 & 50.8 & 3 & 0 & 6 \\
\hline Mar & 5.9 & -4.2 & 0.8 & 12.8 & -8.3 & 104.4 & 4.7 & 939.8 & 355.6 & 6 & 0 & 0 \\
\hline Apr & 20.6 & -2.1 & 4.2 & 19.4 & -11.7 & 10.2 & 4.6 & 101.6 & 76.2 & 2 & 0 & 2 \\
\hline May & 18.4 & 5.4 & 11.9 & 25.6 & -1.1 & 40.1 & 19.6 & 0 & 0 & 3 & 0 & 0 \\
\hline Jun & 24.8 & 10.5 & 17.6 & 32.2 & 3.9 & 21.9 & 6.6 & 0 & 0 & 2 & 12 & 0 \\
\hline Jul & 25.9 & 13.2 & 19.6 & 32.8 & 9.5 & 83.3 & 19.8 & 0 & 0 & 8 & 14 & 0 \\
\hline Aus & 26.9 & 13.2 & 20.0 & 30.6 & 8.9 & 30.5 & 7.6 & 0 & 0 & 4 & 22 & 0 \\
\hline Sep & 22.0 & 8.8 & 15.3 & 27.2 & 2.3 & 56.1 & 47.2 & 0 & 0 & 2 & 1 & 0 \\
\hline Oct & 16.8 & 4.2 & 10.6 & 22.8 & -2.2 & 11.4 & 7.9 & 0 & 0 & 1 & 0 & o \\
\hline Nor & 11.2 & -0.5 & 5.3 & 18.3 & -9.4 & 7.6 & 5.3 & 38.1 & 25.4 & I & 0 & 1 \\
\hline Dec & 4.5 & -6.3 & -0.4 & 12.2 & -21.1 & 1.5 & 1.3 & 25 & - & 0 & 0 & 7 \\
\hline Year & 14.4 & 2.3 & 8.4 & 32.8 & -13.3 & 380.3 & 47.2 & 1256.9 & 355.6 & 32 & 49 & 30 \\
\hline
\end{tabular}

${ }^{\mathrm{a}} \tilde{\mathrm{Z}} 6.7^{\circ} \mathrm{C}=80^{\circ} \mathrm{F} ; \quad-9.4^{\circ} \mathrm{C}=15^{\circ} \mathrm{F}$

during March with $104.4 \mathrm{~mm}, 4$ times normal. Precipitation for the year was $85 \mathrm{~mm}$ less than normal. The distribution of annual precipitation totals for Los Alamos is approximately Gaussian, with a mean of $465 \mathrm{~mm}$ and a standard deviation of $120 \mathrm{~mm}$. The calendar year 1973 is at the 25 th percentile.

\section{Rainfall Distributions}

Distributions of hourly and daily rainfall accumulations observed by a recording rain/snow gauge are shown in Fig. 11. The distributions are highly skewed toward low rates, with a median hourly accumulation of $0.75 \mathrm{~mm}$ and a range of 0.25 to $13.5 \mathrm{~mm}$. Daily accumulations ranged from 0.25 to $50 \mathrm{~mm}$, with a median value of $1.75 \mathrm{~mm}$. There were 80 days $(289 \mathrm{~h})$ with measurable precipitation.

To determine patterns of rainfall, and to aid in estimation of surface run-off and soil moisture movement in the drainage basins around Los Alamos, 72 rain gauges were distributed as widely as possible throughout the county. A record of daily ouservations at each site was compiled from June through October. Table $\mathrm{XXX}$ lists some gross

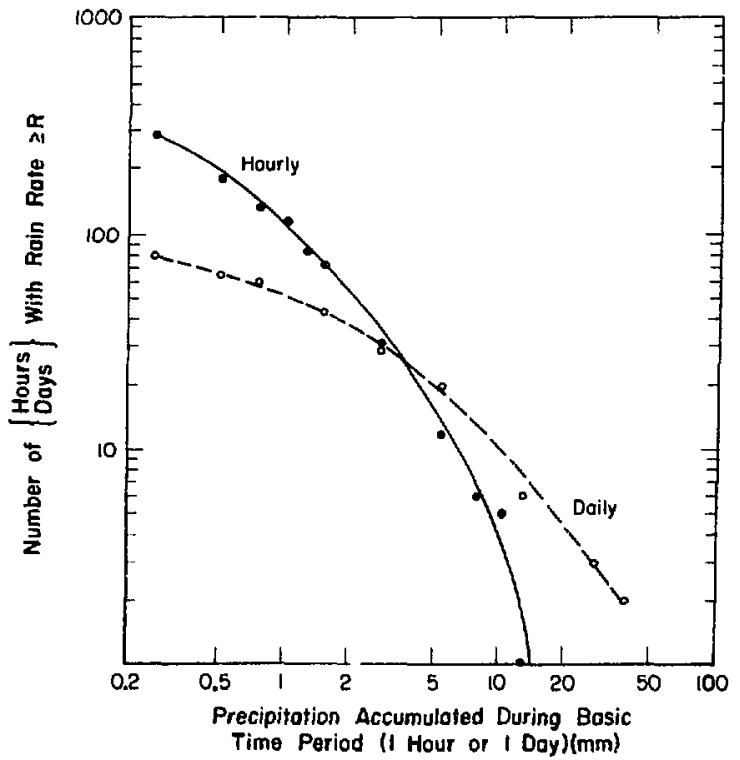

Fig. 11.

Distribution of boturly and daily rainfall rates during 1973. 
TABLE XXX

\section{RAIN-GAUGE NETWORK STATISTICS FOR 1973}

\begin{tabular}{|c|c|c|c|c|c|}
\hline Month & $\begin{array}{c}\text { LASI } \\
\text { Total } \\
\text { (nam) } \\
\end{array}$ & $\begin{array}{l}\text { No. or } \\
\text { Stations } \\
\text { Reporting }\end{array}$ & $\begin{array}{c}\text { Network } \\
\text { Mean } \\
\text { (Im) } \\
\end{array}$ & $\begin{array}{l}\text { Std } \\
\text { Det } \\
\text { (mm) }\end{array}$ & $\begin{array}{c}\text { Coeff } \\
\text { of } \\
\text { Var } \\
\end{array}$ \\
\hline June & 11.9 & 57 & 13.7 & 5.9 & 0.42 \\
\hline July & 83.3 & 63 & 68.7 & 20.5 & 0.30 \\
\hline Aug & 30.5 & 59 & 41.8 & 8.3 & 0.20 \\
\hline Sept & 56.1 & 64 & 55.9 & 9.9 & 0.18 \\
\hline Oet & 11.4 & 54 & 12.2 & 4.4 & 0.36 \\
\hline
\end{tabular}

Data collected at the LASI Ileteorological tower.

statistics for the monthly totals of the 72-station network, giving some indications of the spatial variability of monthly precipitation totals.

Precipitation totals from the LASL meteorological tower are fairly representative of the spatial means. However, the variation of rainfall across the network is quite large. The coefficient of variation (the ratio of the standard deviation to the mean) is between 0.18 and 0.42 . The largest variations were in June and October when much of the rainfall came from a few major thunderstorms.

It is also pertinent to identify consistent aspects of the precipitation patterns. Figure 12 shows the isohyets of the june-through-October rain. The net gradient parallel to the terrain slope is $2-3 \mathrm{~mm} / \mathrm{km}$, and one or more tongues of precipitation maxima are oriented along the terrain gradient. Two primary thunderstorm tracks help to explain the patterns of Fig. 12. The more common track was the west-to-east movement of convective cells originating in the Jemez Mountains. A most probable site of cell formation, such as 3460-ft-high Redondo Peak, could explain a west-to-east oriented rainfall maximum. Such convective cells dimirished as they traveled eastward. The second track led up the Rio Grande valley from the south, occurred far less frequently, but often accounted for very heavy rains. Precipitation diminished as these latter storms moved westward. The rain-gauge network is evidently situated near the edge of these storms. It must be stressed that the conclusions drawn from one season's rainfall data are tentative and only suggestive of possible mechanisms.

\section{Windfield Patterns}

Figure 13 shows the wind roses calculated from the anemometer at the Administration Building (TA-3). The wind roses are stratified into three categories by time of day to reflect the role of low-level buoyancy effects. The noctumal period, from 2000 to 0800 MST, is representative of stable thermal stratification. During the period of insolation, 0800 to $1600 \mathrm{MST}$, the air is generally unstable, and 1600 to 2000 MST is a transition period during which the statistics are strongly affected by transient processes associated with sunset. The nighttime winds show the greatest incidence of calm conditions, $8.2 \%$ of the total hours of record. For all speeds, the winds at TA-3 are dominated by northwest flow (flow from the northwest). This suggests a downslope drainage to account for the light winds. The high incidence of strong northwest winds is also representative of other sites in Los Alamos and reflects a vertical confluence of the free stream flow on the lee of the Jemez Mountains. This effect may account for the majority of record surface winds in the $30-45 \mathrm{~m} / \mathrm{s}$ range observed at Los Alamos over the last 30 years.

Daytime winds at TA-3 are more uniformly distributed in direction than those at night, and have a weak NW-SE axis and secondary maxima in the southerly and northeasterly directions. Again, winds greater than $9 \mathrm{~m} / \mathrm{s}$ are predominantly from the northwest. The transition period also reflected the westerly dominance with a northwesterly maximum occurrence. Previous studies have shown that the weak west-to-northwest drainage flow has the lowest levels of turbulence and therefore results in the poorest dispersion of stack emissions. The terrain configuration at Los Alamos makes it inadvisable to extrapolate the wind rose from a single site or to assume that transport follows straight paths in the proportions indicated in Fig. 13. Several sources of data show that transport winds vary significantly over the area. Wind roses calculated for other years at sites near the ends of mesas show a distinct southerly maximum. One-year records of simultaneous hourly winds at three sites, TA-3, TA-53, and TA-55, covering the period May 1971 to April 1972, have been processed to determine spatial differences in the wind field. One statistic of interest is the fraction of the hours when the wind direction difference between the three sites exceeded 90 degrees. This occurred $20 \%$ of the time, primarily with wind speeds of less than $2 \mathrm{~m} / \mathrm{s}$. These data suggest that the drainage flow, which is quite well organized in the western portion of the Laboratory, closer to the Jemez Mountains, weakens and gives way to a southerly flow created by air channeling through the Rio Grande depression at the eastern end of the Laboratory site. A significant modeling effort will be required to quantify these concepts. 


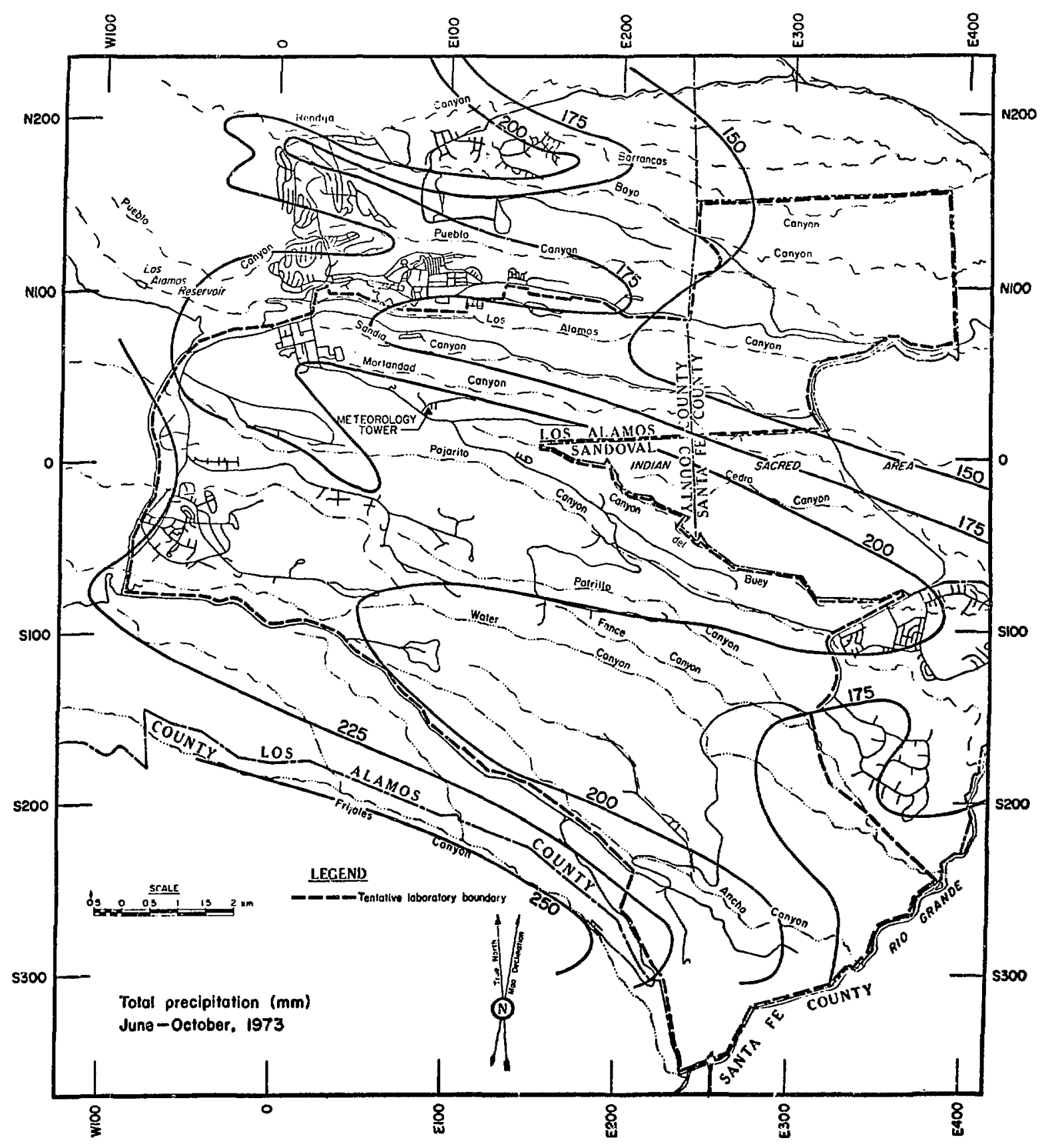

Fig. 12.

Total precipitation isobyets for June through October 1973. 


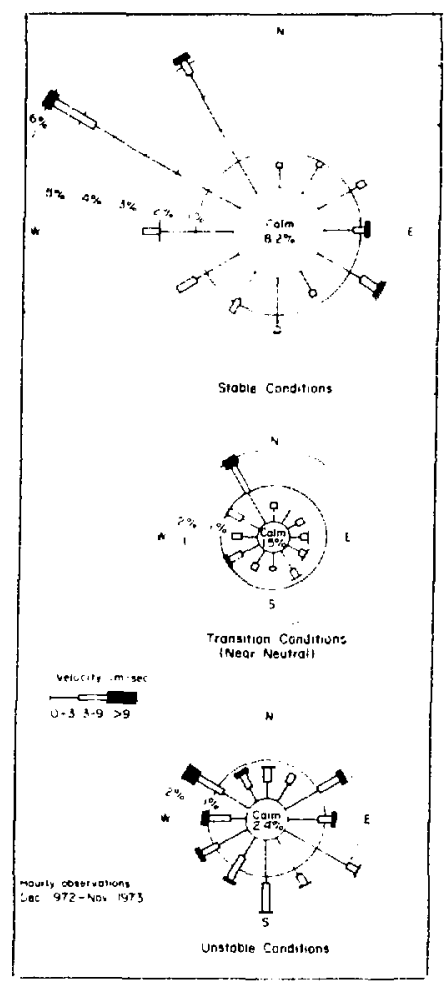

Fig. 13.

Wind roses for Los Alamos, 1973.

\section{GEOLOGY AND HYDROLOGY}

\section{A. Application to Waste Management}

Geo-hydrological studies of the LASL area indicate that buried wastes have been successfully isolated from the hydrologic environment. ${ }^{10}$ Liquid effluents, on the other hand, tend to be retained in stream-connected aquifers in the alluvium of the receiving canyons. The stream flow in these canyons does not usually extend beyond the LASL boundaries because the water is lost by evapo-transpiration from the alluvium. During periods of heavy storm run-off, however, contaminated sediments are transported down the canyons. Any attempt to control the movement of contaminated sediments beyond the LASL boundaries, as well as to design an efficient monitoring program, requires an understanding of the potential seouring action of storm run-off.

\section{B. Flood Frequencies and Maximum Discharges}

There are no surface water data with which to evaluate the flood frequencies and maximum discharges in the canyons of the Los Alamos area. However, there are theoretical projections based on generalized rainfall data and nomographs devised by Scott. ${ }^{11}$ The method uses empirical relationships between existing flood data at gauged sites and the physical and climatic conditions of the corresponding drainage basin. The nomographs are then used to estimate flood frequencies for areas where no direct flood data exist.

Although 16 drainage areas were identified within the LASL boundaries (Fig. 14), only 10 contained the well defined channels necessary for theoretical flood frequency and maximum discharge analyses. Drainage areas were determined from topographic maps; channel slopes were computed on the basis of two points: 15 and $90 \%$ of the distance from the drainage divide to the discharge point at the LASL boundary.

The calculated maxima and frequencies of discharges are shown in Table XXXI; the frequency, or "recurrence interval," is the average time between occurrences of discharges of a given magnitude.

The study of canyon discharge dynamics has just begun, and will be continued in an attempt to develop quantitative models for the transport of sediments through canyons.

\section{ENVIRONMENTAL CONTROLS}

\section{A. Relevance to Surveillance}

Continued surveillance of environmental contaminant; would be of little value if the data were not used to improve environmental protection practices. Conversely, some environmental control activities provide source data that can be used in planning future surveillance programs.

A recent example from LASL operations illustrates the need for close coordination of control and surveillance functions. Three TAs decommissioned over a decade ago were subsequently demolished and decontaminated; the real property was then disposed of to private or public ownership. The small quantities of radioactive contaminants remaining at these locations therefore abruptly became "off-site" by administrative action. Recent requests for more detailed evaluations of these sites indicate the value of thorough and quantitative documentation of 


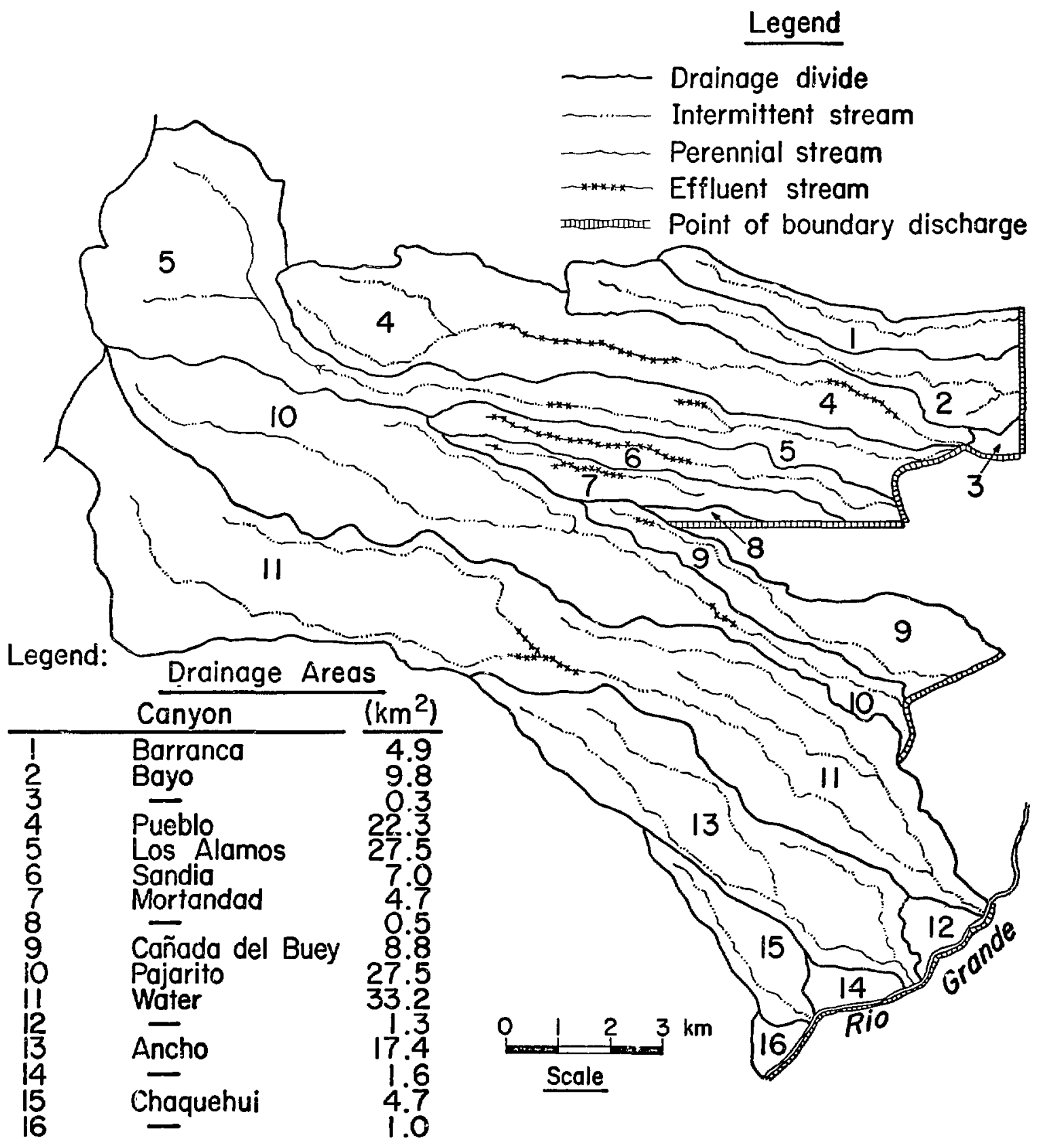

Fig. 14.

Surface water drainage areas. 
TABLE XXXI

\section{FLOOD FREQUENCY AND MAXIMUM DISCHARGE ESTIMATES}

\begin{tabular}{|c|c|c|c|c|c|c|c|}
\hline \multirow{2}{*}{$\begin{array}{l}\text { Drainage Area } \\
\text { Designution }\end{array}$} & \multirow{2}{*}{$\begin{array}{c}\text { Area } \\
\text { Drained } \\
\left(\mathrm{bm}^{2}\right) \\
\end{array}$} & \multirow{2}{*}{$\begin{array}{c}\text { Average } \\
\text { Channe? } \\
\text { Slope } \\
\end{array}$} & \multicolumn{5}{|c|}{ Maximun Discharge $\left(\mathrm{m}^{3} / \mathrm{s}\right)$ by Frequency } \\
\hline & & & $\underline{2 y r}$ & $5 \mathrm{yr}$ & $10 \mathrm{yr}$ & 25 yx & $50 \mathrm{yr}$ \\
\hline 1. Barrancs Canyon & 4.9 & -0.039 & 1.5 & 4.1 & 6.7 & 12 & 14 \\
\hline 2. Bayo Cenyon & 9.8 & -0.028 & 2.4 & 6.1 & 8.5 & 17 & 19 \\
\hline 3. Unnamea ${ }^{b}$ & 0.3 & - & - & - & - & - & - \\
\hline 4. Pueblo Canyon & 22.3 & -0.033 & 3.1 & 7.1 & 10 & 17 & 21 \\
\hline 5. Los Alamos Canyon & 27.5 & -0.040 & 3.0 & 6.8 & 11 & 16 & 20 \\
\hline 6. Sandia Canyon & 7.0 & -0.028 & 2.0 & 5.4 & 2.5 & 16 & 18 \\
\hline 7. Mortandar Canyon ${ }^{c}$ & 4.7 & -0.029 & - & - & $x \rightarrow$ & - & -- \\
\hline 8. Unnamed ${ }^{\mathbf{b}}$ & 0.5 & - & - & - & - & - & - \\
\hline 9. Cañada del Buey & 8.8 & -0.021 & 2.6 & 6.2 & 9.4 & 19 & 21 \\
\hline 10. Pafarito Canyon & 27.4 & -0.039 & 3.0 & 7.3 & 10 & 16 & 20 \\
\hline 11. Water Canyon & 33.2 & -0.050 & 2.8 & 6.8 & 9.6 & 14 & 18 \\
\hline 12. Unnamed ${ }^{b}$ & 1.3 & - & - & - & - & 一 & - \\
\hline 13. Ancho Canyon & 17.4 & -0.045 & 2.3 & 5.4 & 8.2 & 14 & 17 \\
\hline 14. Unnemed ${ }^{b}$ & 1.6 & - & -- & - & -- & - & - \\
\hline 15. Chaquehui Canyon & 4.7 & -0.078 & 1.1 & 3.0 & 4.5 & 8 & 10 \\
\hline 16. Unnamed ${ }^{b}$ & 1.0 & - & - & - & -- & - & - \\
\hline
\end{tabular}

${ }^{a}$ Channel slopes are presented as dimensionless ratios of average vertical distance change (negative to horizontal distance traversed).

brainage area without well defined channel.

Mortandad Canyon is the only major canyon for which no rua-off at boundary is predicted owing to the lack of a main channel in the lower portions.

current decommissioning activities. This turn of events also emphasizes the artificiality of distinguishing between onsite and off-site contamination.

\section{B. Decotnmissioning Surveillance}

Before any demolition takes place, a preliminary survey is conducted in the immediate vicinity of each decommissioned structure. The survey includes measurements of external radiation intensity and the collection and analysis of soil samples or other appropriate environmental media. Results of the survey are used to determine the extent of required decontamination and concomitant costs.

During demolition, special air samplers in the immediate vicinity and daily meteorological forecasts for the local area are used to assess actual and probable releases of pollutants to the environment. A representative of the Environmental Studies Group is authorized to postpone or curtail the operations if weather conditions or decommissioning methods threaten to release excessive quantities of pollutants.

After demolition and decontamination, the site is thoroughly resurveyed for any residual contamination. Members of the Ecology Section are consulted on matters such as soil stabilization, revegetation, and the desirability of ecological studies at the site.

The above procedure was applied to one decommissioned facility during 1973 and will be used for other facilities. It is an important adjunct to the routine environmental surveillance program. 


\section{Construction Quality Assurance Program}

As part of the quality assurance (QA) review for every proposed facility, environmental aspects of the design are reviewed by the Environmental Studies Group. Such factors as site selection and preparation, soil control and drainage, control of gaseous and liquid effluents, and stress on flora and fauna are included in the QA review. The concepts of environmental protection and evaluation are therefore used in the planning stage of a facility, in operational surveillance during the lifetime of the facility, and in the ultimate demolition and disposal of the property.

\section{REFERENCES}

1. J. E. Herceg, Compiler, "Environmental Monitoring in the Vicinity of the Los Alamos Scientific Laboratory, CY 1973," Los Alamos Scientific Laboratory report LA-51 84 (1973).

2. T. E. Hakonson, J. W. Nyhan, and K. V. Bostick, "Ecological Investigation of Radioactive Materials in Waste Disposal Areas at Los Alamos," Los Alamos Scientific Laboratory report LA-5282-MS (1973).

3. L. J. Johnson, "Los Alamos Land Areas Environmental Radiation Survey, 1972," Los Alamos Scientific Laboratory report LA-5097-MS (1972).
4. international Commission on Radioiogical Protection (ICRP), "Report of Committee II on Permissible Dose for Internal Radiation, 1959," ICRP Publ. 2, Pergamon Press, New York (1960).

5. International Commission on Radiological Protection (ICRP), "Recommendations of the International Commission on Radiological Protection," ICKP Publ. 6, Pergamon Press, New York (1962).

6. International Commission on Radiological Protection (ICRP), "Evaluation of Radiation Doses to Body Tissues from Internal Contamination Due to Occupational Exposure," ICRP Publ. 10, Pergamon Press, New York (1968).

7. Radiation Data and Reports 14, 383, Office of Radiation Programs, Environmental Protection Agency, Wash. D. C., June 1973.

8. ICRP Task Group on Lung Dynamics, "Deposition and Retention Models for Internal Dosimetry of the Human Respiratory Trace," Health Physics 12, 173 (1966).

9. International Commission on Radiological Protection (ICRP), "The Metabolism of Compounds of Plutonium and Other Actinides," ICRP Publ. 19, Pergamon Press, New York (1972).

10. W. D. Purtymun and W. R. Kennedy, "Geology and Hydrology of Mesita del Buey," Los Alamos Scientific Laboratory report LA-4660 (1971).

11. A. G. Scott, "Preliminary Flood-Frequency Relations and Summary of Maximum Discharges in New Mexico," US Geological Survey Opeu-file Report (1971). 


\section{UNITS OF MEASUREMENT CONVERSIONS}

\section{Quant1ty}

Radioscifity Concentration

Atrborne

In LIquids

In Solids

\begin{abstract}
$1 \mathrm{pCi} / \mathrm{g}$
\end{abstract}
$1 \mathrm{fCi} / \mathrm{s}$

Chemical Properties

Concentraitions in Liquids $1 \mathrm{mg} / \mathrm{l}$

$1 \mathrm{\mu g} / \mathrm{e}$

$1 \mathrm{ng} / \mathrm{l}$

Exchange Capacity

$1 \mathrm{eq} / \mathrm{kg}$

Electrical Conductance

$2 \mathrm{~ms} / \mathrm{m}$

$1 \mathrm{~m}^{3} / \mathrm{s}$

$12 / 8$

Yeteorological Data

Temperature

Precipitation

und speed

A1r Pressure

Strean Flow Rate
${ }^{\circ} \mathrm{c}$

$2 \mathrm{~mm}$

$1 \mathrm{~m} / \mathrm{s}$

$1 \mathrm{mPa}$
AECM 0524

$=10^{-12} \mu \mathrm{Ci} / \mathrm{me}$

$=10^{-15} \mathrm{\mu Ci} / \mathrm{me}$

$=10^{-10} \mathrm{uci} / \mathrm{me}$

$=10^{-9} \mathrm{kCi} / \mathrm{m} \ell$

$=10^{-12} \omega \mathrm{si} / \mathrm{mR}$

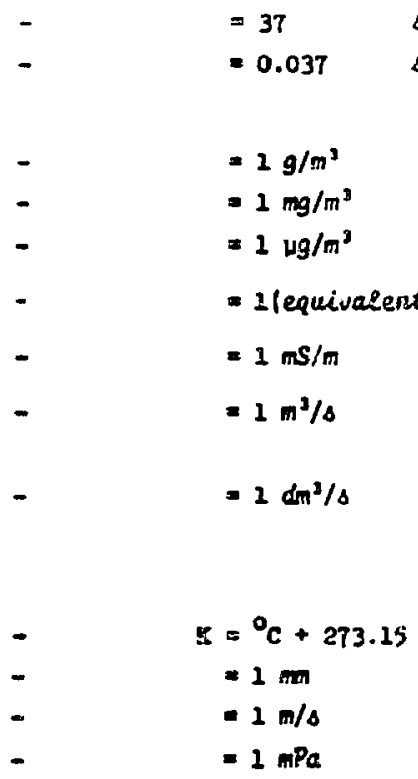

Internationgl (SI) Common Usare

$=0.037 \quad \mathrm{~s}^{-1} \mathrm{~m}^{-3}=1 \mathrm{pCi} / \mathrm{m}^{3}$

$=3.7 \times 10^{-3} \mathrm{~s}^{-1} \mathrm{~m}^{-3}=10^{-3} \mathrm{pCi} / \mathrm{m}^{3}$

$=3.7 \times 10^{-0} \mathrm{~s}^{-1} \mathrm{~m}^{-3}=10^{-6} \mathrm{pci} / \mathrm{m}^{3}$

$=37 \quad s^{-1} m^{-1}=1 \quad p c i / l$

$=0.037 \quad \mathrm{~s}^{-1} \mathrm{~m}^{-3} \quad=10^{-3} \mathrm{pCi} / \mathrm{l}$

$s^{-1} \mathrm{~kg}^{-1}=1 \mathrm{pCi} / \mathrm{g}$

$s^{-1} \mathrm{~kg}^{-1}=10^{-3} \mathrm{pCi} / \mathrm{g}$

$=1 \mathrm{ppm}$

$=1 \quad \mathrm{Fpb}$

$=20^{-3} \mathrm{ppb}$

$=10^{2}$ me $/ 100 \mathrm{~g}$

$=10$ witho $/ \mathrm{cm}$

$=6 \times 10^{\circ} \mathrm{lprt}$

- $2120 \mathrm{cjm}$

- $60 \mathrm{epm}$

$=2.12 \mathrm{cs}$

$$
\begin{aligned}
\mathrm{O}_{\mathrm{F}} & =2.8\left({ }^{\circ} \mathrm{c}\right)+32 \\
& =0.039 \text { irsh } \\
& =0.447 \mathrm{mph} \\
& =9.87 \times 10^{-3} \text { atmos. } \\
& =10 \mathrm{mbar} \\
& =0.145 \mathrm{poi} \\
& =0.295 \mathrm{int} . \mathrm{kg}
\end{aligned}
$$

- $8.11 \times 10^{-6}$ ac. $6 t$ 0.0353 c6s

- $25.9 \mathrm{gmm}$

- 2.28 = 10" gad

- 35.3 cfo

- $1.59 \times 10^{\circ} \mathrm{gpm}$

- $2.28 \times 10^{7} \mathrm{gpd}$ 


\section{APPENDIX B}

\section{STANDARDS PERTAINING TO EFFLUENT AND ENVIRONMENTAL MONITORING}

(Excerpts from AEC Manual Chapter 0550, Appendix, March 26, 1973)

\section{Part II. Environmental Protection}

$$
\text { Prescribed: }
$$

Prevention, Control, and Abatement of Air and Water Pollution, AECA 05jo.

Afr and Water Pollution Control Standards Promulgeted Pursuant to the Clean Air Act (42 U.S.C. 1857 et seg.) and the Federal Heter Pollution Control Act ( 33 U.S.C. 466 et seq.).

Intrastate or Interstate Regulations of Mir and Water Pollution Control Authorities.

Erfluent and Environmental Monitoring and Reporting, AECM 0513.

Recomended:

Standard Methods for the Examinetion of Hatex. Sewage, and Industrial Hastes (AWHA).

Manual of Septic-Tank Practice, Pub. Do. 526 (USPHS).

Sanltary Landrill Factg. Pub. No. 1792 (USPHS). Inter $1=$ Cufde of Cood Practlce for Incineration at

Federal Facillitics, Pub. Ho. AP-46 (USFHS). Incinerator Guidelines, Pub. Ho. 2012 (USPHS).

Alr Pollution Englncering Manual, Pub. Io. AP-40 (USPHS).

\section{Part IV. A. Badsation Protection}

Preseribed:

Standard: ro: Radlation Protection, AECS 0524 Recorzended:

Applicable (FRC) Reports (1960, 19-1962, 15-1964。 87-2965. 18 (Rerised).

Handbooks, HCRP Recorezendations (NBS).

Culde to Sanpling Alrborne Radleact Ive Materlels in suclear Facility $113.2-1969$ (ANST).

Speeffication and Perforance of On-site Inatzumentation for Continuougly monitorins Radiaactivisy in Errluents, 113 Serles (ANSI) in Draft status.

Part IV. D. Publie Health and Sandtaeion

Prescribed:

Drinkine Water Stajdards, Builetin 956 (EPA).

Manual of Recormended Uater-Senitation Practice, Bulletin 525 (EPA).

Manual of Water quality end Treatment (ArHa).
Sanitation Manial for Public Ground Hater Supplies, Reports 59:137-17?, Reprint 2539 (EPA).

Stanaards and Specifications for Hater Supply. Treatment, Distribution System, and Storsge Equipment, Materials, and Procedures (AWHA).

Pert VII. F. Radioactive Haste Management

\section{Prescribed:}

Radioaetive Waste Menagement, AECI 0,11. (Manual chepter in preporation.)

Plail for the Management of AEC-Generated Radionct1ve Hastes, HASH-1202 (GPO).

Sources of Supply for Standarda

(ANSI) American Hational Standards Institute 1403 Breadway

New York, New York 10018

(AHrA) Anezican Weter Works Association 2 Park Arenue Dew York, New Tork 22603

(EPA) Environmental Prctection Agency $401 \times$ Street S.H. Weshington, D.C. 20024

(FRC) Federsl Radistion Counc1l Hesh1ngton. D.C. 20449

(APO) Superintendent of Doctorents Ualted States Goverment Printing orfice Hashington, D.C. 20402

(FiB) Jatioaal Burcau of Standards Departwent of Comerce Hashington, D.C. 20234

(USPHS)Uuited States Public Health Service Departaent of Health, Education, and velfare Uash1ngton. D.C. 20203 


\section{MINIMUM DETECTION LIMITS (MDLS) FOR ROUTINE ANALYSES OF RADIOACTIVITY IN TYPICAL ENVIRONMENTAL SAMPLES}

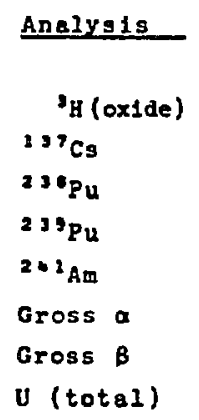

\begin{tabular}{|c|c|c|c|c|}
\hline \multicolumn{3}{|c|}{ Liquids } & \multicolumn{2}{|c|}{ Solids } \\
\hline $\mathrm{Cor}$ & nc. & $(\% \mathrm{CG})$ & \multicolumn{2}{|c|}{ conc. } \\
\hline 0.3 & $10^{-6} \mu \mathrm{Ci} / \mathrm{ml}$ & $(0.01)$ & 3 & $n C i / \ell^{c}$ \\
\hline 0.3 & ${ }^{10^{-6}} \mu \mathrm{Ci} / \mathrm{ml}$ & $(1.5)$ & 0.1 & $p C i / g$ \\
\hline 50 & $10^{-12} \mu \mathrm{Ci} / \mathrm{ml}$ & $(0.001)$ & 5 & $\mathrm{fCi} / \mathrm{g}$ \\
\hline 50 & $10^{-12} \mu \mathrm{Ci} / \mathrm{ml}$ & $(0.001)$ & 5 & $\mathrm{fCi} / \mathrm{g}$ \\
\hline 50 & $10^{-12} \mu \mathrm{Ci} / \mathrm{ml}$ & $(0.002)$ & 5 & $\mathrm{GCi} / \mathrm{g}$ \\
\hline 0.3 & $10^{-9} \mu \mathrm{Ci} / \mathrm{ml}$ & $(0.006)$ & 3 & $p C i / g$ \\
\hline 3 & $10^{-9}{ }_{\mu} \mathrm{Ci} / \mathrm{ml}$ & (1) & 1 & $\mathrm{pCi} / \mathrm{g}$ \\
\hline 10 & $n g / \ell^{d}$ & $(0.0001)$ & 10 & $n g / g^{d}$ \\
\hline
\end{tabular}

a.DL as percent of CGs cannot be stated for solids such as soils and sediments since there are no puolished CGs for these materials.

The trttium coneentration is meesured in atwospheric water vapor and converted to a concentration in air on the basis of the relative humidity during the collection period. The listed velue is considered typical for this region.

conly the tritium contained in the unbound water of the sample is analyzed.

Total wass concentrations of uranium are ietermined suorometrically; conversion to activity depends on the 1sotopic composition of the mater1el. 


\section{APPENDLX D}

\section{CONCENTRATION GUIDES (CGs) FOR UNCONTROLLED AREAS ${ }^{a}$}

\section{CONCENTRATION GUIDES FOR UICONTROLLED AREAS ${ }^{\mathrm{a}}$}

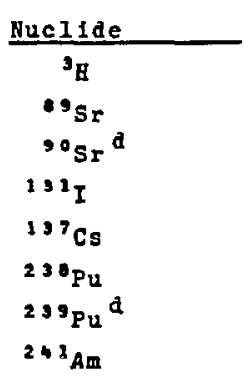

U, natural

Nuelide

${ }^{3} \mathrm{H}$
${ }^{9} \mathrm{Sr}$
${ }^{\circ} \mathrm{Sr}^{\mathrm{a}}$
$13{ }^{13} \mathrm{I}$
$230^{\circ \mathrm{Pu}}$
$239 \mathrm{Pu}^{\mathrm{d}}$
$241 \mathrm{Am}$

U, natural

$3 \times 10^{-12}$

\begin{tabular}{l}
$\frac{\mathrm{co}}{(\mathrm{uCl} / \mathrm{m} \ell)}$ \\
\hline $2 \times 10^{-7}$ \\
$3 \times 10^{-10}$ \\
$3 \times 10^{-11}$ \\
$1 \times 10^{-10}$ \\
$2 \times 10^{-9}$ \\
$7 \times 10^{-14}$ \\
$6 \times 10^{-14}$ \\
$2 \times 10^{-13}$
\end{tabular}

CG for AIr

$\frac{\left(p C i / \mathrm{m}^{3}\right)^{b}}{2 \times 10^{5}}$
300
30
100
2000
0.07
0.06
0.2

\begin{tabular}{cc}
\multicolumn{2}{c}{ CG for Water } \\
\hline$\frac{(\mu \mathrm{C} i / \mathrm{ml})}{3 \times 10^{-3}}$ & $\frac{(n \mathrm{C} i / \ell)^{b}}{3000}$ \\
$3 \times 10^{-6}$ & 3 \\
$3 \times 10^{-7}$ & 0.3 \\
$3 \times 10^{-7}$ & 0.3 \\
$2 \times 10^{-5}$ & 20 \\
$5 \times 10^{-6}$ & 5 \\
$5 \times 10^{-5}$ & 5 \\
$4 \times 10^{-6}$ & 4
\end{tabular}

$\frac{\left(\mu g / m^{3}\right)^{c}}{g}$

$2 \times 10^{-5}$

$\frac{(\mathrm{mg} / \ell)^{\mathrm{C}}}{60}$

\section{CONCENIRATION GUIDES FOR CONTROLLED AREAS}

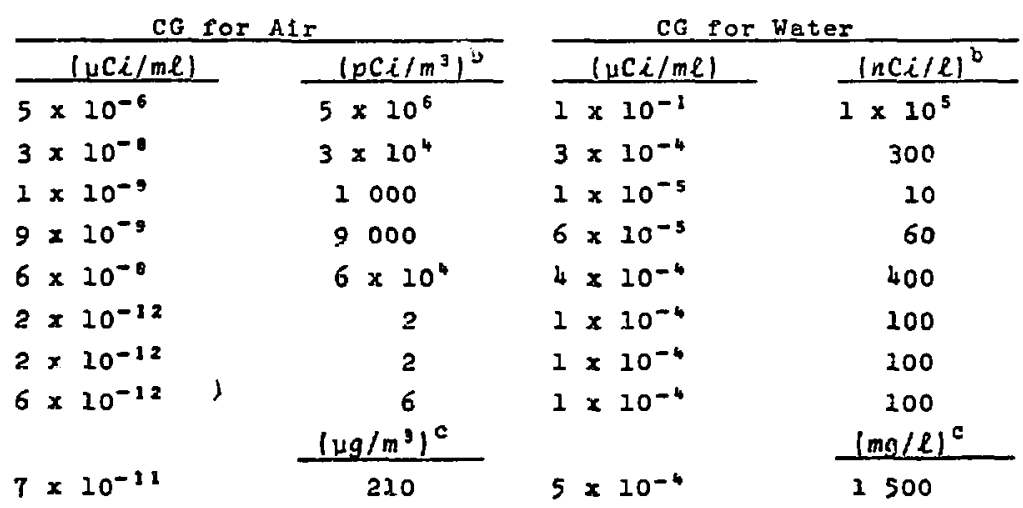

Tais teble contains the most restrictive CGs for nuclidas of major interest at LASL (AEC Manual Ch.0524, Annex A).

${ }^{b}$ Although units of $\mu \mathrm{Ci} / \mathrm{m} \ell$ are used for all $\mathrm{CG}_{3}$ in $\mathrm{AECM} 0524$, units of $\mathrm{m}^{3}$ for air volumes and $\ell$ for 11 quid volumes are given in this report because of their convenience and wide acceptance; these units are combined with standard metric prefixes as appropriate for the range of values reported.

Finorometric measurement.g of $U$ mass concentrations may be converted to activity concentrations using the factor $0.33 \mathrm{uCi} / \mathrm{g}$.

${ }^{d}$ of the possible radionuclides released at LASL, ${ }^{9} \mathrm{Sr}$ and ${ }^{2}{ }^{9} \mathrm{Pu}$ are the most restrictive. The CGs for these species are used for the gross bets and gross alpha cGs, respectively. 


\section{APPENDIX E}

\section{WATER STANDARDS}

"DPINTCING WATER STANDARDS" FOR CHFMTCAIS

\section{Concentration Limit (mg/l) PHS and EPA ${ }^{a}$}

Constituent Symbol Mandatory Recommended NMWQCC Alkyl benzene

$\begin{array}{llccc}\text { sulfonate } & \text { ABS } & - & 0.5 & - \\ \text { Arsenic } & \text { As } & 0.05 & 0.01 & 0.05 \\ \text { Barium } & \text { Ba } & 1.0 & - & 1.0 \\ \text { Boron } & \text { B } & - & - & 0.75 \\ \text { Cadmium } & \text { Cd } & 0.01 & - & 0.01\end{array}$

Carbon chloroform

Chlorine CI

Chromium bexavalent total

$\mathrm{Cr}^{+6}$

\subsection{5}

$-$

$0.2-$

Copper

cu

$-$

$\overline{0.01}$

Cyanide

$$
\text { CN }
$$$$
-
$$

$$
1.0
$$

$0.05(0.1)^{c}$

Fluoride

0.2

Iron

$$
\text { F }
$$$$
\text { n!d }
$$

0.02

$-$

\section{Lead}

Manganese

$\mathrm{Fe}$

$-$

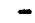

0.3

0.05

$-$

0.05

Mer cury

$$
\text { Pb }
$$$$
-
$$$$
0.05
$$

0.1

Molybdenum

$$
\text { Hg }
$$

Nickel

Mo

N5.

$$
-
$$$$
-
$$$$
0.001
$$$$
-
$$$$
0.01
$$

Mitrate no,

Phenols

Selenium

silver

Se

Ag

Total dis-

solved solids TDS

zinc

2n
45.

$$
0.001
$$

0.01

0.05

$\begin{array}{ll}- & 0.01 \\ - & 0.05\end{array}$

500.

$$
5.0 \quad 0.1(0.5)^{c}
$$

MISCELLANEOUS WATER STANDARDS

Radioactivity in drinking water (PHS):

Gross beta activity:

$1000 \mathrm{pci} / \mathrm{l}$

(if strontium-90 and alpha emitters

are not present)

Strontium-90:

$10 \mathrm{pCi} / \mathrm{l}$

Radium-226:

$3 \mathrm{pci} / \mathrm{l}$

Bfological quelity for drinkins water (MNQCC):

Single Composite of Sample 5 daily samples

Biological oxpren demand,BOD: $160 \mathrm{mg} / \mathrm{l} \quad 30 \mathrm{mg} / \mathrm{l}$

Chemical oxygen demand,COD: $150 \mathrm{mg} / 2 \quad 125 \mathrm{mg} / \mathrm{l}$

Settleable solids:

$1.0 \mathrm{ml} / \mathrm{l} \quad 0.5 \mathrm{ml} / \mathrm{l}$

Fecal coliform organisms:

$500 / 200 \mathrm{~m} \ell-$

pH:

$6.6-8.6-$

Quality factors for fisheries ${ }^{a}$ and recreational

waters (MNGQCC):

Maximum temperature: $70^{\circ} \mathrm{F}$

Maximum temperature increase: $2^{\circ} \mathrm{F}$

Dissolved oxycen DO (and BOD): nat to drop to less than $50 \%$ of saturation or $6.0 \mathrm{mg} / \mathrm{l}$, whichever is ereater.

Coliform organisms:

for fisheries: $\quad 2000 / 100 \mathrm{ml}, 5$-day Arith $\mathrm{Avg}$

for contact sports: $200 / 100 \mathrm{ml}, 5$-aay Geos Mean

aIl streams above $5000 \mathrm{ft}$ in elevation are considered to be trout producing.

PHS Regulations on Drinking Water Standards,

42 CFR 72, 201-207, Fed. Reg. 27:2152, Mar.6,1962.

Also in PHS Publ. 956 and EPA Bulletin 956.

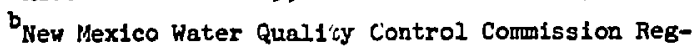

wlations (see text).

concentrations shown in parentheaes are permitted

in community sewer systems.

$d_{\text {The concentration standard for fluoride varles }}$

depending upon temperature, but is centered around

$2 \mathrm{mg} / \mathrm{l}$. 